\title{
CROSS-TRADING AND LIQUIDITY MANAGEMENT: EVIDENCE FROM MUNICIPAL BOND FUNDS
}

\author{
by \\ JINGYUN YANG
}

\begin{abstract}
A DISSERTATION
Presented to the Department of Finance and the Graduate School of the University of Oregon in partial fulfillment of the requirements for Doctor of Philosophy
\end{abstract}

June 2018 


\section{DISSERTATION APPROVAL PAGE}

Student: Jingyun Yang

Title: Cross-trading and Liquidity Management: Evidence from Municipal Bond Funds

This dissertation has been accepted and approved in partial fulfillment of the requirements for the Doctor of Philosophy degree in the Department of Finance by:

$\begin{array}{ll}\text { Z. Jay Wang } & \text { Chair } \\ \text { Diane Del Guercio } & \text { Core Member } \\ \text { Youchang Wu } & \text { Core Member } \\ \text { Jeremy Piger } & \text { Institutional Representative }\end{array}$

and

Sara D. Hodges Interim Vice Provost and Dean of the Graduate School

Original approval signatures are on file with the University of Oregon Graduate School.

Degree awarded June 2018. 
(c) 2018 Jingyun Yang 


\section{DISSERTATION ABSTRACT}

Jingyun Yang

Doctor of Philosophy

Department of Finance

June 2018

Title: Cross-trading and Liquidity Management: Evidence from Municipal Bond Funds

The high flow-performance sensitivity in open-end municipal bond funds motivates fund managers to actively manage funding liquidity risk and reduce the costs of flowdriven transactions. Funds with volatile past flows build up liquidity buffers by holding more cash and liquid municipal bonds in their portfolios. Funds rely on cash and liquid securities in flow management. Unconventional liquidity management tools, such as crosstrading between funds in the same family, are used by municipal bond funds in extreme situations. Fund families coordinate cross-trades between open- and low-value closed-end funds only when open-end funds are in distress. 


\section{ACKNOWLEDGMENTS}

I thank my committee chair, Z. Jay Wang, for his encouragement and helpful suggestions and comments. I am thankful for useful suggestions and comments from my dissertation committee members: Diane Del Guercio, Youchang Wu and Jeremy Piger. I also thank participants in the workshop at the University of Oregon. I am grateful to John Chalmers, Z. Jay Wang and Steve Liu for generously sharing municipal bond transaction costs data. 


\section{TABLE OF CONTENTS}

Chapter

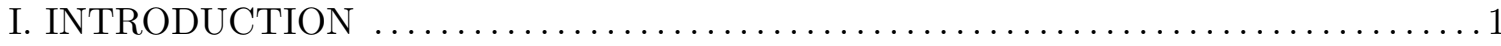

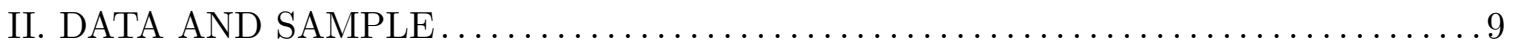

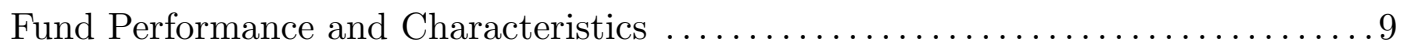

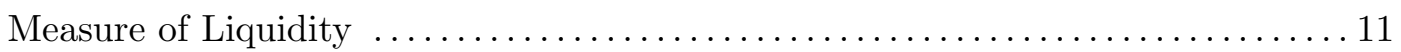

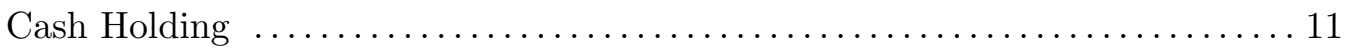

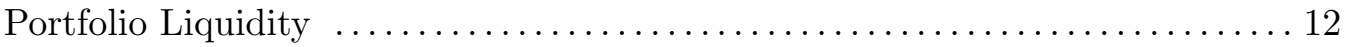

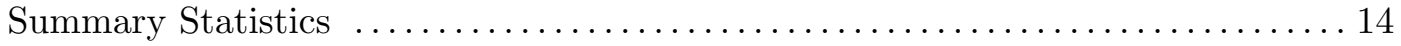

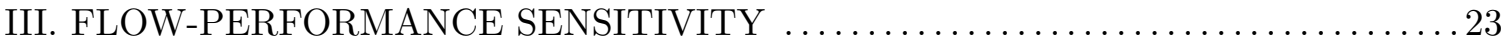

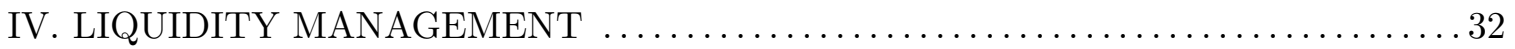

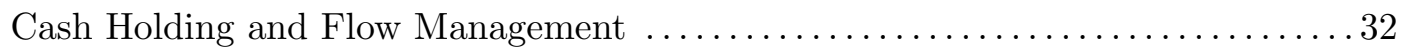

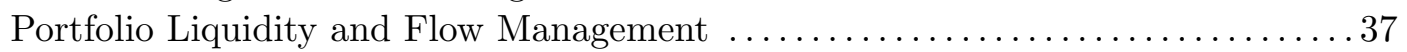

V. CROSS-TRADING AND LIQUIDITY MANAGEMENT $\ldots \ldots \ldots \ldots \ldots \ldots \ldots \ldots . \ldots 4$

Measure of Cross-trading and Matched-sample Methodology ................. 44

Fund Flows and Cross-trading between Open- and Closed-end Funds . . ....... 46

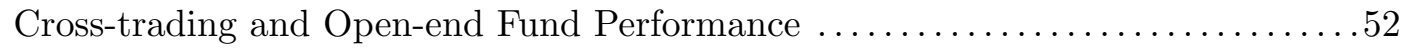

Cross-trading and Closed-end Fund Characteristics ....................... 55

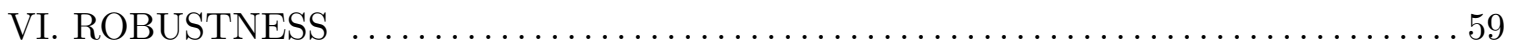

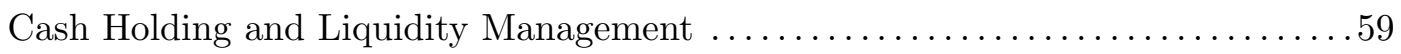

Cross-trading between Open- and Closed-end Funds........................ 61

Cross-trading and Characteristic-matched Sample $\ldots \ldots \ldots \ldots \ldots \ldots \ldots \ldots \ldots \ldots$

Cross-trading Policy of Investment Advisors ....................... 67

2SLS - Cross-trading and Open-end Fund Performance .................. 73

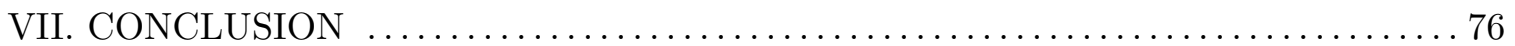

APPENDICES

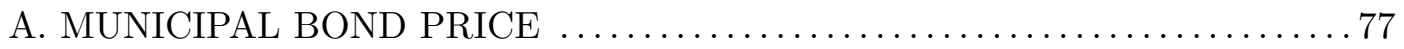

B. CASH HOLDINGS IN THE PREVIOUS LITERATURE $\ldots \ldots \ldots \ldots \ldots \ldots \ldots 78$

C. CORRELATION MATRIX FOR PORTFOLIO LIQUIDITY $\ldots \ldots \ldots \ldots \ldots . . . . .80$

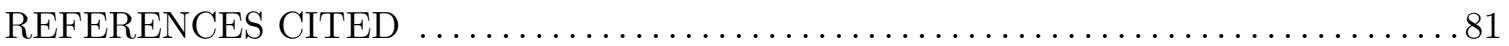




\section{LIST OF FIGURES}

Figure $\quad$ Page

1. Quarterly Flow-performance Relationship - Rank of Past Performance ..........25

2. Monthly Flow-performance Relationship - Rank of Past Performance .......... 26

3. Quarterly Flow-performance Relationship - Past Performance .............. 27

4. Monthly Flow-performance Relationship - Past Performance $\ldots \ldots \ldots \ldots \ldots \ldots \ldots 28$ 


\section{LIST OF TABLES}

Table

1. Summary Statistics for Open- and Closed-end Funds ...................... 15

2. Cash and Portfolio Liquidity for Open-end Funds ........................ 19

3. Flow-performance Sensitivity of Open-end Funds ......................... 29

4. Open-end Funds' Cash Holdings and Flow Management $\ldots . \ldots \ldots \ldots \ldots \ldots \ldots . \ldots 33$

5. Open-end Funds Portfolio Liquidity and Flow Management ....................39

6. Summary Statistics of Cross-trading between Open- and Closed-end Funds ..... 47

7. Cross-trading and Open-end Fund Flows $\ldots \ldots \ldots \ldots \ldots \ldots \ldots \ldots \ldots \ldots \ldots \ldots \ldots \ldots \ldots \ldots \ldots \ldots \ldots$

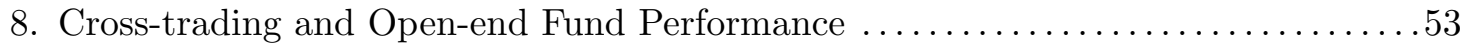

9. Cross-trading and Closed-end Fund Characteristics $\ldots \ldots \ldots \ldots \ldots \ldots \ldots \ldots \ldots$

10. Robustness Test of Open-end Fund Cash Holdings and Flow Management .......59

11. Alternative Matching: Cross-trading between Open- and Closed-end Funds .....6 63

12. Alternative Matching: Cross-trading and Open-end Fund Flows $\ldots \ldots \ldots \ldots \ldots 65$

13. Investment Advisors' ACT: Cross-trading between Open- and Closed-end Funds . 69

14. Investment Advisors' ACT: Cross-trading and Open-end Fund Flows ......... 71

15. 2SLS regression: Cross-trading and Open-end Fund Performance $\ldots \ldots \ldots \ldots \ldots .74$ 


\section{CHAPTER I}

\section{INTRODUCTION}

Liquidity management is important for open-end funds due to their liquidity transfer roles. Open-end funds provide liquidity to their investors by allowing investors to redeem shares at the net asset value on a daily basis. However, liquidity transformation hurts fund performance for several reasons. First, funds have to liquidate their holdings in a short period upon investor redemption requests. These forced liquidations may happen at dislocated prices during fire sale events (Shleifer and Vishny (1997), Brunnermeier and Pedersen (2009) and Coval and Stafford (2007)) and impose large, negative externalities on the rest of investors who stay with the funds (Johnson (2004)). Second, funds have to build liquidity buffers in order to avoid costly fire sales. Liquidity buffers such as cash holdings reduce fund performance because high liquidity is associated with low expected returns.

The literature on mutual fund liquidity management is relatively small but growing fast in recent years. Previous studies look at mutual fund liquidity management using cash and cash equivalents (Yan (2006), Fulkerson and Riley (2016) and Chernenko and Sunderam (2016)) and derivatives such as futures and credit default swaps (Koski and Pontiff (1999), Frino, Lepone and Wong (2009) and Jiang and Zhu (2015)). The recent literature studies cash and liquidity management in corporate bond funds (Jiang, Li and Wang (2016)). The literature also provides evidence on other liquidity management channels. Agarwal and Zhao (2016) study family-level liquidity management using interfund lending programs. Chernenko and Sunderam (2016) find economies of scale in cash holdings at the family-level and provide evidence on interfund lending programs. In this paper, I contribute to the literature by investigating the liquidity management mechanisms of open-end municipal bond funds and the impact of liquidity management on fund performance. In additional to examining the use of cash and liquid securities in liquidity management, I find evidence on an alternative liquidity management channel, cross- 
trading, which is only used in extreme situations. Specifically, I find that fund families use closed-end funds to provide liquidity to distressed open-end funds by coordinating cross-trades through the family internal market.

Liquidity management is particularly important for municipal bond funds. Flowdriven transactions are very costly in the municipal bond market because of the low market liquidity. Funds with insufficient cash and liquid holdings suffer from large losses due to investor flow shocks. However, liquidity buffers such as cash holdings decrease funds' future performance. Moreover, recent literature finds that fund runs and fire sales are more likely to happen if the mutual funds invest in illiquid assets. Zeng (2017) builds a theoretical model and shows that mutual funds with illiquid holdings may experience fund runs even with optimal liquidity management. In an illiquid market, mutual funds that experienced outflows optimally re-build cash buffers by liquidating their holdings, but these sales of illiquid assets lead to poor future performance. Therefore, rational investors seeking first-mover advantage redeem their shares, leading to fund runs. This theoretical model is consistent with recent empirical evidence on the mutual fund flowperformance relationship. Chen, Goldstein and Jiang (2010) find that outflows of equity funds are more sensitive to bad past performance when the funds hold illiquid assets. Goldstein, Jiang and Ng (2017) find that the flow-performance relationship is concave for corporate bond funds, indicating that investor outflows are highly sensitive to poor past performance. Since the municipal bond market has low market liquidity, I expect that investors have incentives to seek first-mover advantage by withdrawing their assets from open-end municipal bond funds. Such redemption requests force municipal bond funds to liquidate their illiquid holdings, leading to poor performance in the future.

I begin with testing the flow-performance relationship in open-end municipal bond funds. I find evidence that municipal bond fund flows are highly sensitive to past performance, especially poor past performance. In the region of positive returns, an $1 \%$ increase in funds' past performance can attract $0.27 \%$ investor inflows per month. In the region of negative returns, an $1 \%$ decrease in funds' past performance can cause $0.44 \%$ investor 
outflows. The high flow-performance sensitivity, together with the low liquidity of the municipal bond market, imposes large liquidity risk on municipal bond funds. Therefore, municipal bond funds have strong incentive to manage liquidity risk.

Next, I investigate how municipal bond funds use conventional tools, namely cash and liquid securities, to manage liquidity risk. Cash is one of the most liquid assets in the financial market and the most widely used liquidity management tool in asset management. If open-end funds have high funding liquidity risk, fund managers will build cash buffers to prepare for unexpected investor flows. Fund managers can also hold liquid financial securities in their portfolios so that they can earn positive expected returns while having low transaction costs at liquidity-driven trading. I collect data on municipal bond funds' quarterly holdings from Morningstar and find that the average open-end municipal bond fund invests $1.52 \%$ net assets in cash and cash equivalents and $98.27 \%$ net assets in municipal bonds. I also use the quarterly holding data from CRSP. Consistent with the results from Morningstar, CRSP also reports that open-end municipal bond funds have low cash holdings. Open-end municipal bond funds on average hold $2.23 \%$ cash and 97.74\% municipal bonds. Funds with higher funding liquidity risk, as proxied by past flow volatility, hold more cash and more liquid municipal bonds. When open-end funds' monthly flow volatility increases by $1 \%$, the funds will hold additional $0.22 \%$ net assets in cash. When open-end funds' flow volatility increases by $1 \%$, the average 12 -month trading volume of their municipal bond holdings increases by 1.52 million and the average 12-month bid-ask spread decreases by 2.3 basis points. Consistent with municipal bond funds using cash and liquid securities to accommodate investor flows, their cash position change and portfolio liquidity change are positively associated with the concurrent flows. I also find that open-end funds in large families hold less cash, suggesting economics of scale in cash management at fund family level.

The low cash holdings in municipal bond funds seem to be surprising. Intuitively, municipal bond funds should hold more cash than equity and corporate bond funds because the municipal bond market is less liquid than the equity and corporate bond mar- 
kets. However, previous literature finds that past flow volatility, rather than the market liquidity, is the key determinant of cash holdings. For example, the recent SEC mutual fund liquidity white paper (Hanouna et al. (2015)) finds that U.S. equity funds have average cash holdings of $3.1 \%$ and monthly flow volatility of $5.8 \%$, U.S. bond funds have cash holdings about $2.5 \%-2.9 \%$ and monthly flow volatility around $4.9 \%-6.6 \%$, and U.S. municipal bond funds have cash holdings of $1.9 \%$ and monthly flow volatility around $2.7 \%{ }^{1}$ Consistent with the previous literature, I also find that open-end municipal bond funds have low cash holdings around $1.52 \%-2.23 \%$ and low average flow volatility of $1.47 \%$. I conclude that the average open-end municipal bond funds do not hold excessive cash because they have less volatile flows than equity and corporate bond funds.

Even though open-end municipal bond funds do not have volatile flows, liquidity management is still a major task of fund managers because of the high transaction costs in municipal bond market. The average transaction costs (bid-ask spread) of municipal bond fund portfolios in my sample are 66.5 basis points. If open-end fund managers liquidate their portfolios proportionally to meet investor redemption requests, this is the transaction costs they pay. However, I find that a fund portfolio's average bid-ask spread only changes by 27 basis points following flow shocks, suggesting that fund managers use liquid municipal bonds in their portfolios to accommodate fund flows. I find similar results using trading volume, Amihud liquidity and zero-trading as the liquidity measure.

In addition, open-end municipal bond funds can experience large flows in extreme situations. The top and bottom 5th percentiles of quarterly flows are $10.74 \%$ and $-7.77 \%$. Given the illiquid nature of the municipal bond market, traditional liquidity management tools are unlikely to be sufficient to absorb extreme flow shocks. Compared to other types of open-end funds, municipal bond funds are more likely to explore alternative liquidity management tools in extreme situations. Specifically, I focus on cross-trading as an unconventional liquidity management channel. In case of large investor redemptions, dis-

\footnotetext{
${ }^{1}$ Please find summary statistics of cash holding and flow volatility in previous literature in Appendix Table B1 and B2.
} 
tressed open-end funds are forced to liquidate their assets at dislocated prices. However, if distressed open-end funds cross-trade with affiliated funds through the family internal market $^{2}$, they may be able to avoid costly fire sales.

Cross-trading has been used as a liquidity management tool in the asset management industry, especially at extreme circumstances. For example, Pimco sold about $\$ 18$ billion of Pimco Total Return's assets to other Pimco funds in order to meet more than $\$ 100$ billion of redemptions that followed Bill Gross's surprise exit in September $2014^{3}$. Family-level cross-trading can be useful in liquidity management for open-end funds with illiquid assets for several reasons. First, funds can avoid expensive transaction costs if they cross-trade in the family internal market. It is well known that the municipal bond market is one of the most illiquid financial market in the U.S.. Chalmers, Liu and Wang (2017) shows that the average round-trip dealer's markup (transaction costs) is around 200 basis points or even higher for transactions worth less than $\$ 25 \mathrm{k}^{4}$. There is also anecdotal evidence that investment advisors avoid transaction costs through cross-trading. For example, in an investigation against Western Asset Management, the SEC finds that "by avoiding exposing the cross-traded securities to the market, Western saved market costs totaling approximately $\$ 12.4$ million" ${ }^{5}$. Second, municipal bond funds can avoid the negative price impact of flow-driven transactions by cross-trading in family internal market. During fire sales of illiquid assets, asset prices could drop significantly and may

\footnotetext{
${ }^{2}$ Rule 17 a-7 under the 1940 Act allows cross-trading in the family internal market can take place if: 1) cross-trading funds are affiliated solely by reason of having a common investment adviser; 2) the transaction price should be the independent current market prices, and the "current market price" for certain securities (such as municipal securities) is calculated by averaging the highest and lowest current independent bid and offer price; 3) the transaction is consistent with the investment policy of each participating fund; 4) no brokerage commission, fee (except for customary transfer fees), or other remuneration is paid in connection with the transaction; 5) the transaction is approved by the fund's board of director. More details on cross-trading regulations can be found in the two SEC staff interpretive letters: United Municipal Bond Fund (July 30, 1992) and Federated Municipal Funds (Nov. 20, 2006).

${ }^{3}$ See Bloomberg artical Pimco May Have Averted Fire Sale After Gross's Exit and Pimco Total Return's annual shareholder reports for more details on the fund's in-house clearance sale.

${ }^{4}$ See Figure 1 in Chalmers, Liu and Wang (2017) for more details on municipal bond transaction costs.

${ }^{5}$ See Western Asset Management Co., Investment Company Act Release No. 30893 (Jan. 27, 2014) for details on Western Asset Management cross-trading violations.
} 
take weeks or even months to reverse. If distressed open-end funds cross-trade with peer funds, they can avoid the abnormal negative returns during fire sales.

I expect that cross-trading is concentrated in fund families that manage both openand closed-end funds because closed-end funds are immune to investors flows and therefore are good candidates for providing liquidity. When fund families coordinate crosstrades, they can transfer performance from closed- to open-end funds by setting the transaction prices beneficial to open-end funds. This would improve the performance of distressed open-end funds and reduce fund outflows. Meanwhile, the closed-end funds do not suffer outflows after poor performance. The net effect will be an increase in fund family value. I do not expect fund families to coordinate cross-trades between open-end funds because such cross-trades tend to be zero-sum games. If one open-end fund benefits from cross-trading, the other will bear losses and therefore experience subsequent outflows. Outflows from poor-performing funds and inflows to good-performing funds offset each other and the fund family value remains the same.

To investigate whether open-end funds use family-coordinated cross-trading in liquidity management, I follow the cross-subsidization literature to use offsetting holding changes between funds to estimate cross-trading and use matched sample methodology to test whether family-level liquidity management exists through cross-trading. First, I test whether open-end funds cross-trade with affiliated closed-end funds and whether these cross-trades are associated with flows of open-end funds. I find evidence that fund families only coordinate cross-trades when open-end funds experience extreme outflows. I also find evidence that cross-trading concentrates in one direction: distressed open-end funds cross-sell to affiliated closed-end funds. I use different matching methods and find consistent evidence of cross-trading as an alternative liquidity management tool for distressed open-end funds. I also use hand-collected information on investment advisors' cross-trading policy from Form ADV and find that the relationship between cross-trading and open-end fund flows only exists when the fund families allow cross-trading between two member funds. 
Second, I study how cross-trading affects open-end fund performance. In the OLS regression, I find that cross-trading is negatively associated with open-end fund performance. This could be due to endogeneity since distressed open-end funds with poor performance and large outflows are more likely to engage in cross-trading. To address the endogeneity, I use investment advisors' cross-trading policy collected from Form ADV as the instrumental variable and find that cross-trading is no longer associated with poor open-end fund performance.

Finally, I study whether cross-trading is associated with fund investment styles and characteristics. I find that cross-trading happens mostly between open- and closedend funds with the same investment style and that national funds cross-trade more than single-state funds. This strong style effect is consistent with the SEC regulation that cross-trading must be consistent with the investment policy of each participating fund. I also explore whether cross-trading is related to certain open- and closed-end fund characteristics, such as expense ratio, fund age and fund size. For open-end funds, I find no significant relationship between cross-trading and fund characteristics. The strong association between cross-trading and open-end fund flow, together with the lack of association between cross-trading and open-end fund characteristics, suggests that fund families mainly use cross-trading as a liquidity management channel. In contrast, I find evidence that fund families prefer to use low-value closed-end funds, such as mature funds and lowfee funds, to provide liquidity to peer open-end funds. These results are consistent with family cross-subsidization (Gaspar, Massa and Matos (2006)) and family-value maximization.

This paper makes three main contributions. First, the paper contributes to the literature of cash and liquidity management. Consistent with prior research on other types of funds, I find that municipal bond funds build liquidity buffers to reduce the impact of potential fire sales. I find evidence that municipal bond funds use cash and liquid municipal bonds to meet investor redemptions to avoid high transaction costs in the illiquid municipal bond market. 
Second, the paper provides new insight into on family-level liquidity management tools. Most previous studies focus on liquidity management using cash and derivatives. Recent studies provide evidence of family-level liquidity management. Agarwal and Zhao (2016) looks at interfund lending programs. Chernenko and Sunderam (2016) find economies of scale in liquidity management at the fund family level and explore liquidity management using lines of credit and interfund lending within the fund family. I also find economies of scale in cash holding at the fund family level and provide evidence that fund families coordinate cross-trades between open- and closed-end funds to support distressed openend funds.

Last, it adds to the literature of flow-performance sensitivity. The literature finds strong evidence of a convex flow-performance relationship in equity mutual funds. For example, Brown, Harlow and Starks (1996), Chevalier and Ellison (1997) and Sirri and Tufano (1997) find that investors inflows are very sensitive to good past performance, while outflows are not sensitive to poor past performance. Recent studies, such as Goldstein, Jiang and Ng (2017), examine the flow-performance relationship in corporate bond funds and find a concave relationship. This paper provides evidence on the concave flowperformance relationship in municipal bond mutual funds.

The rest of the paper is as follows: Section 2 describes the sample data and summary statistics. Section 3 tests the flow-performance relationship in municipal bond funds. Section 4 studies liquidity management using cash and liquid municipal bonds. Section 5 provides evidence of cross-trading as an unconventional liquidity management tool. Section 6 shows robustness tests of cash management and cross-trading in liquidity management. Section 7 summarizes the main findings of this paper. 


\section{CHAPTER II}

\section{DATA AND SAMPLE}

I obtain fund returns, characteristics and quarterly portfolios from Morningstar database. The open-end fund sample includes all actively-managed U.S. open-end municipal bond funds from January 2002 to June 2016. I exclude index funds and fund of funds. Openend funds are required to have at least 5 million in net asset value and 1 year in age to be included in the sample. The closed-end funds sample period is from January 2002 to March 2016. I do not apply size or age sample filter to closed-end funds because I expect that closed-end fund characteristics are associated with cross-trading between open- and closed-end funds 6 .

\subsection{Fund Performance and Characteristics}

Morningstar Direct reports returns and characteristics for each share class of U.S. municipal bond funds. I use share class data to calculate fund-level returns and characteristics. $N A V_{t}$ is a fund's total net asset value across all share classes at the end of quarter $t$. Age is the number of years since the inception of a fund's oldest share class. Expense is the NAV-weighted average annual expense ratio across all share classes of a fund. Turnover is the weighted average annual turnover ratio. Institutional is the NAV of a fund's institutional share class as a percentage of the fund's NAV.

An open-end fund's FamilyNAV is the total net asset value of all open-end funds the family. An open-end fund's Family $N A V_{C E F}$ is the total net asset value of all closedend funds in the family and 0 if the fund family does not manage closed-end fund. I obtain the snapshot of municipal bond funds' family names, investment advisors and subadvisors at the end of June 2016 from Morningstar Direct and hand-collect historical information about municipal bond funds' families from SEC Edgar filings in the follow-

\footnotetext{
${ }^{6}$ In untabulated robustness tests, I get statistically similar results after requiring closed-end funds to be at least 5 million in size and 1 year in age.
} 
ing steps. First, I search a fund's earliest and latest available NSAR and N-CSR forms between 2002 and 2016 to identify its family names at the beginning and the end of the sample period. Second, I compare these two fund family names. If the family names are the same, I assume that the fund belongs to the same family during the sample period. If the two family names are different, I search the fund's N-CSR forms between 2002 and 2016 for discussion of fund family changes. A fund is assumed to change families during the sample period if its investment company has M\&As or asset sale events. A fund is assumed to remain in the same family if the difference in reported family names is because of renaming of the investment company and its subsidiaries ${ }^{7}$ Lastly, I perform a web search to verify the historical fund family information. To better illustrate how Family $N A V$ is calculated, I use Invesco California Tax-Free Income Fund as an example. Morningstar Direct shows the fund family name as Invesco at the end of June 2016. However, a search in the SEC filings shows that it was previously owned by Morgan Stanley and known as Morgan Stanley California Tax-Free Income Fund. The fund name and family name changed when Invesco acquired Morgan Stanley's retail asset management business on June 1, 2010. Since the web search results confirm the asset sale between Invesco and Morgan Stanley in 2010, I conclude that this fund belongs to Morgan Stanley before June 2010 and Invesco after June 2010 . Before June 2016, the fund's FamilyNAV is the total NAV of all open-end funds managed by Morgan Stanley and its subsidiary, Van Kampen Investments. After June 2016, its FamilyNAV is the total NAV of all open-end funds managed by Invesco.

A fund's quarterly Flow ${ }^{9}$ is defined as: $F l o w t=\frac{N A V_{t}-N A V_{t-1} \times R_{t}}{N A V_{t-1}}$, where $R_{t}$ is

\footnotetext{
${ }^{7}$ For example, DWS Investments was renamed Deutsche funds on $\mathrm{Au}-$ gust 11, 2014. An example of Deutsche funds' N-CSR can be found at: https://www.sec.gov/Archives/edgar/data/203142/000008805315000018/ar103114stmb.htm.

${ }^{8}$ Invesco California Tax-Free Income Fund semiannual shareholders report in 2010 can be found at: https://www.sec.gov/Archives/edgar/data/1112996/000095012310083678/h74591nvcsrs.htm. The fund was formerly know as Morgan Stanley California Tax-Free Income Fund. Its 2009 annual shareholders report can be found at: https://www.sec.gov/Archives/edgar/data/745992/000110465910012937/a102259_1ncsr.htm.

${ }^{9}$ Fund flows are truncated at the top and bottom $1 \%$.
} 
the fund's quarterly gross return. FlowVol $l_{12}\left(\right.$ FlowV $\left._{24}\right)$ is the standard deviation of a fund's monthly flows in the past 12 (24) months.

A fund's past 1-year performance (PastPerf) is the intercept from a regression of net excess returns on excess stock market and municipal bond market returns in the past 12 months. I use CRSP value-weighted market index as proxy for stock market and the Vanguard total bond market index fund as proxy for bond market. A fund's quarterly return (Ret) is the weighted average NAV-return of all share classes. A fund's quarterly alpha $(\alpha)$ is the quarterly cumulative abnormal return, estimated from a regression of the fund's monthly net excess returns on excess stock market and bond market returns. I use the past 24 months as estimation window, CRSP value-weighted market index return as the stock market return and Vanguard total bond market index fund return as the bond market return. ${ }^{10}$ Ret $V_{\text {ol }} l_{12}$ is the standard deviation of a fund's monthly net returns in the past 12 months.

\subsection{Measure of Liquidity}

I use cash holdings and the average liquidity of the municipal bonds held by an open-end fund to measure the liquidity of the fund.

\subsubsection{Cash Holding}

I combine portfolio weights from Morningstar mutual fund quarterly holdings and Morningstar Direct to calculate cash position, Cash, for open-end municipal bond funds. I obtain the portfolio weights in cash and cash equivalents from Morningstar quarterly holdings. A holding is identified as cash and cash equivalents if it has type code as one of the following: $\mathrm{C}$ (cash), $\mathrm{CD}(\mathrm{CD}$ or time deposit), $\mathrm{CP}$ (commercial paper), $\mathrm{CR}$ (repurchase agreement), $\mathrm{FM}$ (money market fund), $\mathrm{CH} / \mathrm{CL} / \mathrm{CO} / \mathrm{CQ} / \mathrm{CS} / \mathrm{CU} / \mathrm{CV} / \mathrm{CX}$ (currency and

\footnotetext{
${ }^{10}$ Fund performance are truncated at the top and bottom $1 \%$.
} 
currency based derivative), and OO/OS/OT(cash derivative offsets) ${ }^{11}$. When cash positions are missing in Morningstar quarterly holdings, I obtain the portfolio weights in cash and cash equivalents, including cash, CDs, T-bills, commercial paper, money market fund and repurchase agreement, from Morningstar Direct. I use Morningstar quarterly holdings to calculate the portfolio weights in municipal bonds for open-end funds. Cash and municipal bond positions are truncated at the top and bottom $1 \%$.

One drawback of using cash holdings from Morningstar is that almost half observations in the sample have missing value in cash holdings. Therefore, I also obtain open-end municipal bond funds' cash holdings, $C a s h_{c r s p}$, and municipal bond holdings, Muni $i_{c r s p}$ from CRSP database. Cash holdings in CRSP database can be matched with $82.7 \%$ of fund-quarter observations in the sample. However, CRSP database has drawbacks as well. First, CRSP only provides open-end funds' municipal bond holdings after 2008. Second, Schwarz and Potter (2016) find that CRSP contains inaccurate position information prior to 2008. I use cash positions from Morningstar to conduct the liquidity management tests and use cash positions from CRSP as the robustness check.

\subsubsection{Portfolio Liquidity}

I also use the liquidity of municipal bonds held by a fund to measure the fund's liquidity:

$$
\text { PortLiquidity }_{t}=\sum_{b=1}^{N_{t}} w_{b, t} \text { Liquidity }_{b, t},
$$

where Liquidity $_{b, t}$ is the liquidity measure for each municipal bond $b$ held by the fund in quarter $t, N_{t}$ is the total number of municipal bonds held by the fund in quarter $t$, and $w_{b, t}$ is the fund's portfolio weight for bond $b$ at quarter $t$.

I use trading volume, bid-ask spread, Amihud liquidity and zero-trade to measure a municipal bond's liquidity. All liquidity variables for municipal bonds are computed us-

\footnotetext{
${ }^{11}$ I randomly pick 15 open-end municipal bond funds and compare the quarterly cash holdings in Morningstar to the semi-annual holdings in Form N-CSR. The cash positions in Morningstar and Form N-CSR are mostly consistent.
} 
ing Municipal Securities Rulemaking Board (MSRB) municipal bond trading database, which reports the price, size, and time for each municipal bond transaction in the overthe-counter market. The database also reports each municipal bond transaction type as dealer-purchase, dealer-sell, or inter-dealer. I obtain municipal bond transaction data from January 2001 to June 2016.

The first measure is round-trip trading volume. A municipal bond's monthly trading volume is the total size (par value in millions) of all dealer-purchase transactions in a month. I use a municipal bond's trading volume in the past 3 months and 12 months to measure the bond's liquidity. AvgVolume 3 and AvgVolume $_{12}$ is the weighted average past 3-month and 12-month trading volume of municipal bonds held by a fund. The trading volume variables are truncated at the top $1 \%$.

The second measure is bid-ask spread (round-trip trading cost), also called dealer's markup. I obtain the estimates of trading costs for municipal bond round-trip transactions between January 2001 to June 2015 from Chalmers, Wang and Liu (2016). A municipal bond's bid-ask spread over a period of 3 months (12 months) is the weighted average trading costs for all round-trip transactions in the period, using trade size as weight. AvgSpread $_{3}$ and AvgSpread 12 is the weighted average past 3-month and 12-month bidask spread of municipal bonds held by a fund. The bid-ask spread variables are truncated at the top and bottom $1 \%$.

The third measure is a modified version of Amihud (2002) liquidity measure. The Amihud liquidity measures the price impact of a trade per unit traded. It is defined as the daily absolute return to the dollar trading volume on a day. I adopt the modified measure from Dick-Nielsen, Feldhütter and Lando (2012). For each municipal bond in day t, modified Amihud liquidity is defined as the daily average of absolute returns $r_{j}$ divided by the trade size $Q_{j}$ (in million $\$$ ) of consecutive transactions:

$$
\text { Amihud }_{t}=\frac{1}{N_{t}} \sum_{j=1}^{N_{t}} \frac{\left|r_{j}\right|}{Q_{j}}=\frac{1}{N_{t}} \sum_{j=1}^{N_{t}} \frac{\left|\frac{P_{j}-P_{j-1}}{P_{j-1}}\right|}{Q_{j}}
$$

where $N_{t}$ is the number of returns on day t. At least two transactions are required 
on a given day to calculate the daily Amihud liquidity measure. I define a municipal bond's 3-month (12-month) Amihud liquidity as the median of daily Amihud liquidity in that period. AvgAmihud 3 and AvgAmihud 12 are the weighted average past 3-month and 12month Amihud liquidity of municipal bonds held by a fund. The Amihud liquidity variables are truncated at the top $1 \%$.

The forth measure is zero-trade. If a municipal bond does not appear in the MSRB database in a month, I consider the bond as a zero-trade bond in that month. ZeroTrade 3 and $Z$ eroTrade 12 are a fund's portfolio weights in municipal bonds that have zero trading activity in the past 3 months and 12 months. The zero-trade variables are truncated at the top $1 \%$.

\subsection{Summary Statistics}

Table 1 Panel A shows the summary statistics for open-end fund characteristics. The open-end fund sample consists of 890 funds, including 356 national funds (Morningstar category in High Yield Muni, Muni National Long, Muni National Interm, and Muni National Short) and 534 single-state funds. Fund size is positively skewed. The average quarter-beginning NAV is 673.07 million, and the median fund size is 200.13 million. The average open-end funds have 17.48 years since the inception of their oldest share classes. Open-end funds have average annual expense ratio of $0.77 \%$ and turnover ratio of $28.11 \%$. The average funds have $18.32 \%$ net assets in institutional share class. There are 166 fund families that manage open-end funds in my sample. Family size is also positively skewed. The average family size is 12333.81 million and the median family size is 6599.2 million. 


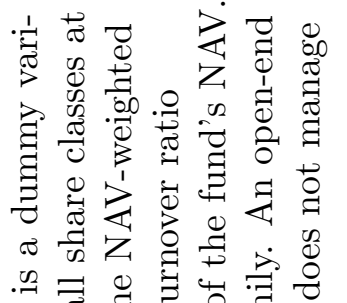

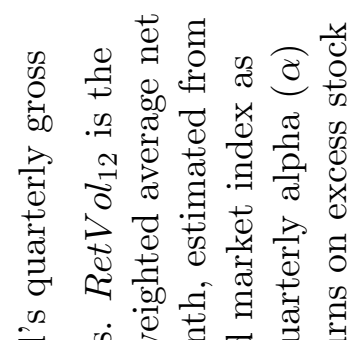

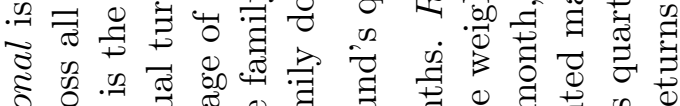

ऽ

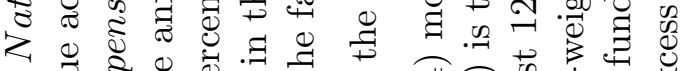

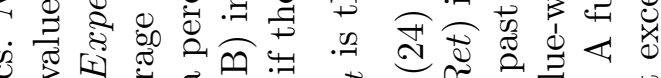

0
0
$\Xi$
0
0
0
0
0
0
0
0
0
0
0
0

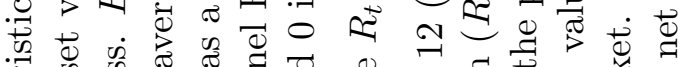

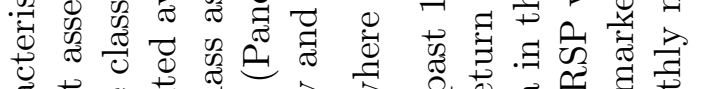

记

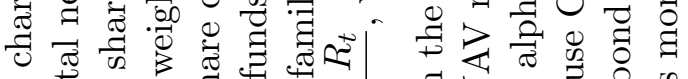

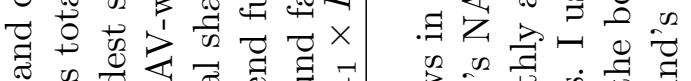

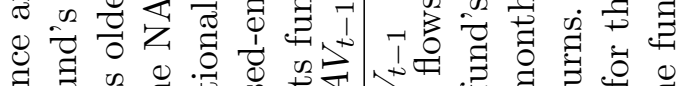

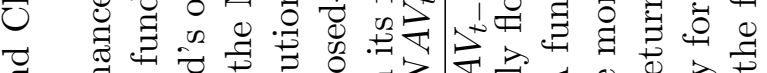

สี

$\stackrel{1}{8}$

t.

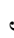

.

.

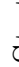

章

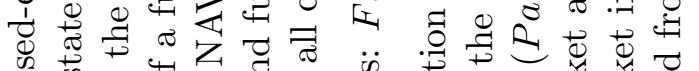

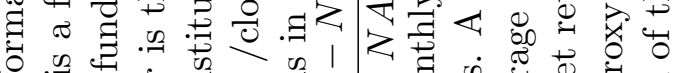

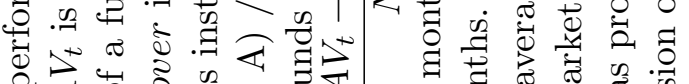

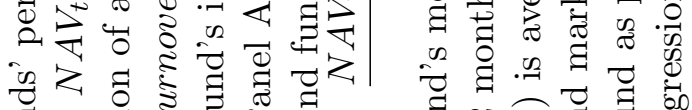

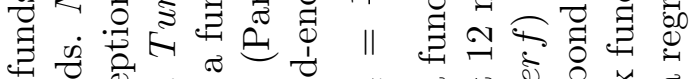

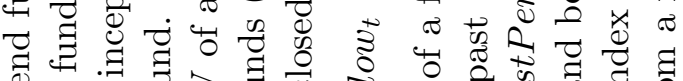

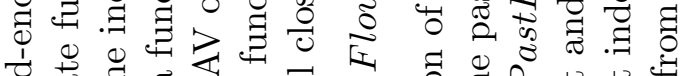

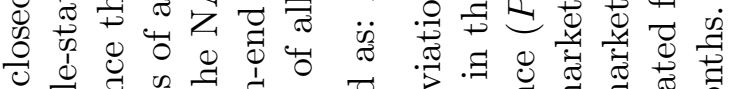

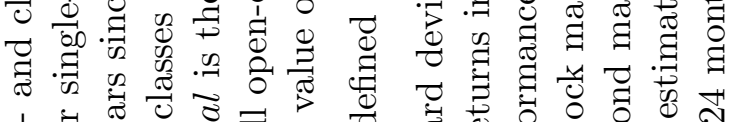

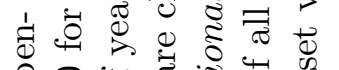

के

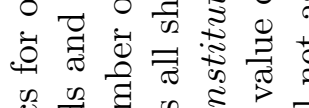

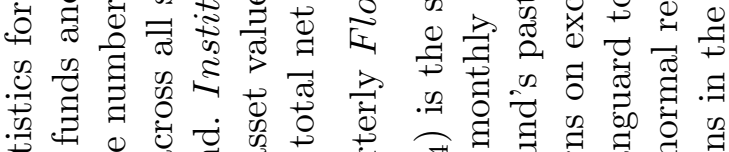

g

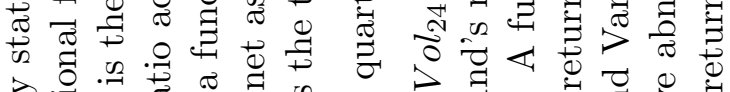

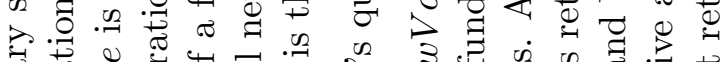

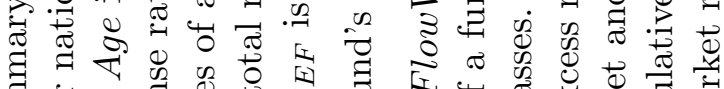

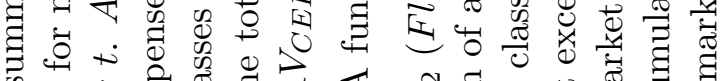

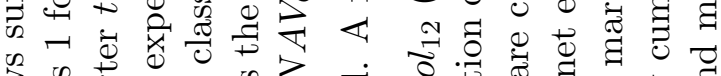

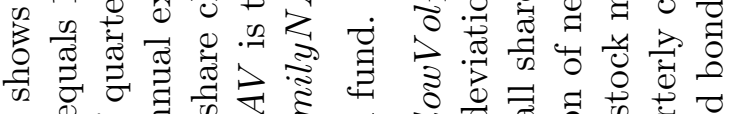

क ष

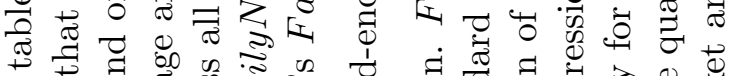

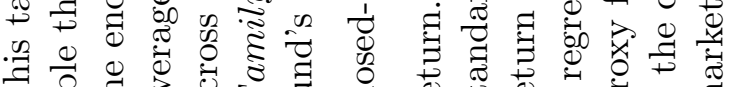

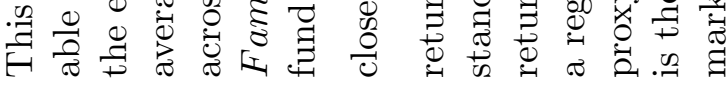

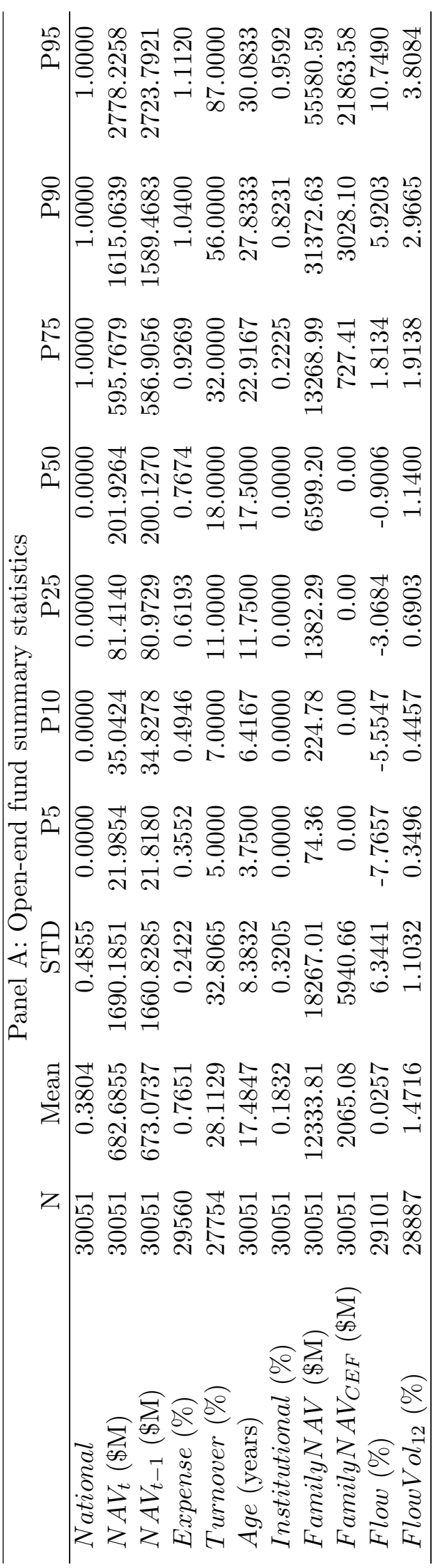




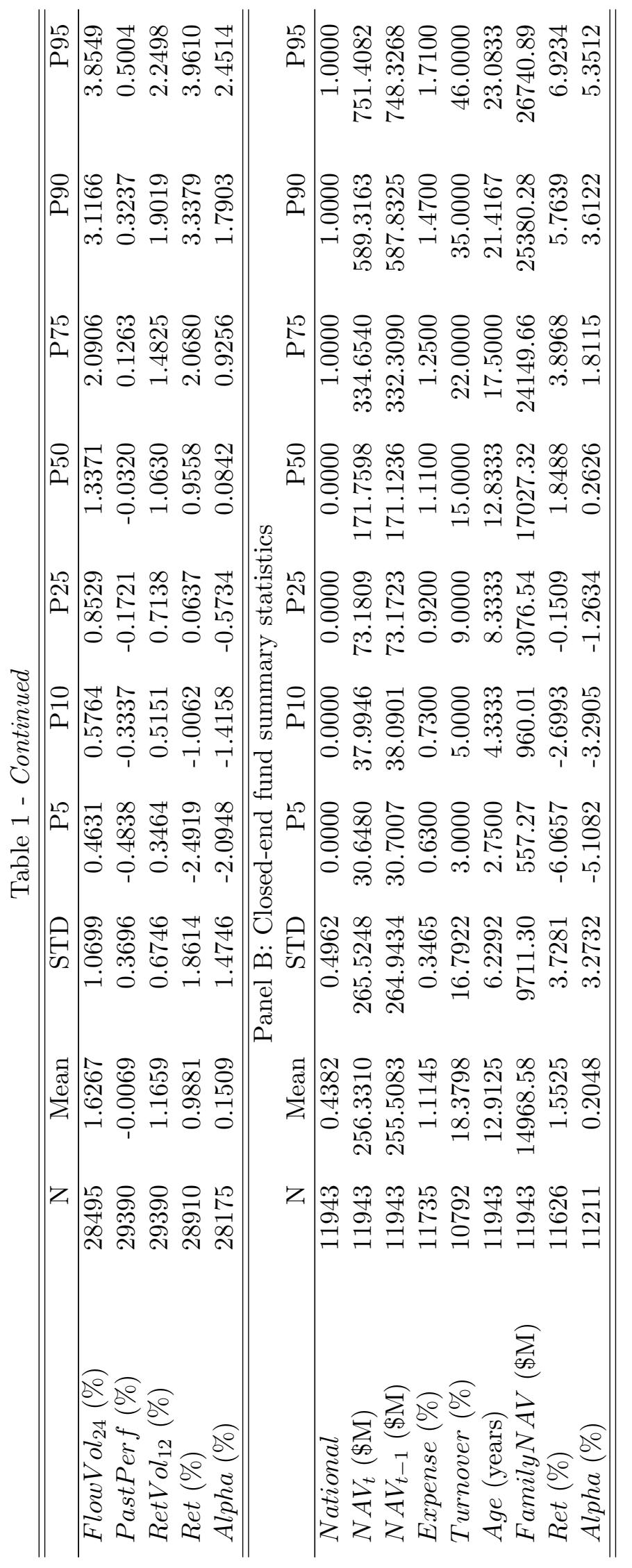


Open-end fund flow and performance have large variations in the cross section. The standard deviation of quarterly flows is $6.34 \%$ and the top and bottom 5 percentiles are $10.74 \%$ and $-7.77 \%$. The average past 12 -month flow volatility is $1.47 \%$. Open-end funds' average past 1-year performance is -6.29 basis points with a standard deviation of $0.14 \%$. The average quarterly net return is $0.98 \%$ and the average quarterly alpha is $0.15 \%$, suggesting that open-end municipal bond funds, on average, do not outperform the market. However, fund performance have large variations in the cross section. The bottom 5th percentile of quarterly alpha is $-2.09 \%$ and the top 5 th percentile is $2.45 \%$.

Table 1 Panel B shows the summary statistics for closed-end fund performance and characteristics. The closed-end fund sample consists of 303 funds, including 135 national and 168 single-state funds. The average quarter-beginning NAV for closed-end funds is 255.51 million and the median fund size is 171.12 million. The average closedend funds have 12.9 years in age. Closed-end funds charge higher expense and fees than open-end funds. The average annual expense ratio for closed-end funds is $1.11 \%$. The average turnover ratio is $18.38 \%$. There are 26 fund families in the closed-end fund sample. The average family size is 14968.58 million. Closed-end funds have higher return and alpha than open-end funds. The average closed-end funds earn $1.55 \%$ net return and $0.2 \%$ abnormal return per quarter. Closed-end funds performance have larger variations in the cross section than open-end funds. The bottom and top 5th percentiles of closed-end funds quarterly alpha are $-5.11 \%$ and $5.35 \%$.

Table 2 Panel A shows the summary statistics for cash positions of open-end funds. Both Morningstar and CRSP report low cash holdings for open-end municipal bond funds. The average cash position is $1.52 \%$ according to Morningstar. The median cash position is $0.73 \%$ and the top and bottom 25 th percentiles are $0 \%$ and $4.36 \%$. Open-end municipal funds rarely take short positions in cash and cash equivalents. The bottom 5 th percentile of cash position is 0 , suggesting that less than $5 \%$ open-end funds use leverage. The cash positions from CRSP are consistent with those from Morningstar. According to CRSP, open-end municipal bond funds, on average, hold $2.23 \%$ net assets in cash and 
cash equivalents. The top and bottom 25th percentiles of cash positions are $0 \%$ and $6 \%$. Table 2 Panel A also shows the summary statistics for open-end funds' portfolio liquidity. The average open-end funds hold $46.21 \%$ (28.89\%) net assets in municipal bonds that are not traded in the past 3 (12) months. The average 3-month (12-month) trading volume of municipal bonds held by an open-end fund is 4.62 million (17.28 million) in par value. The average 3-month (12-month) bid-ask spread of municipal bonds held by an open-end fund is 66.5 (30.24) basis points. The average 3-month (12-month) Amihud liquidity of municipal bonds held by an open-end fund is $0.3 \%(0.29 \%)^{12}$.

Table 2 Panel B compares open-end fund characteristics and liquidity by family types. I divide open-end funds into two groups by whether the fund family simultaneously manages open- and closed-end funds. Among the 166 open-end fund families in my sample, 23 families also manage closed-end funds. Open-end funds in these 23 families tend to have lower flow volatility and hold significantly less cash and less liquid municipal bonds in their portfolios. The average cash holding from Morningstar is $1.39 \%$ for open-end funds in families managing both open- and closed-end funds, while the average cash holding is $1.52 \%$ for open-end funds in families managing only open-end funds. I find consistent results using cash positions from CRSP. Open-end funds in families managing both open- and closed-end funds, on average, hold $1.54 \%$ cash, while those in families managing only open-end funds hold $1.68 \%$ cash. The mean cash holdings across the two groups are significantly different with p-value less than $1 \%$. Open-end funds also hold significantly less liquid municipal bonds, measured by the average bid-ask spread and Amihud liquidity when the fund families manage closed-end funds at the same time. I do not find significant difference between open-end fund's portfolio liquidity, measured by the average trading volume.

\footnotetext{
${ }^{12}$ See Appendix Table C1 for the correlation matrix for the portfolio liquidity measures.
} 


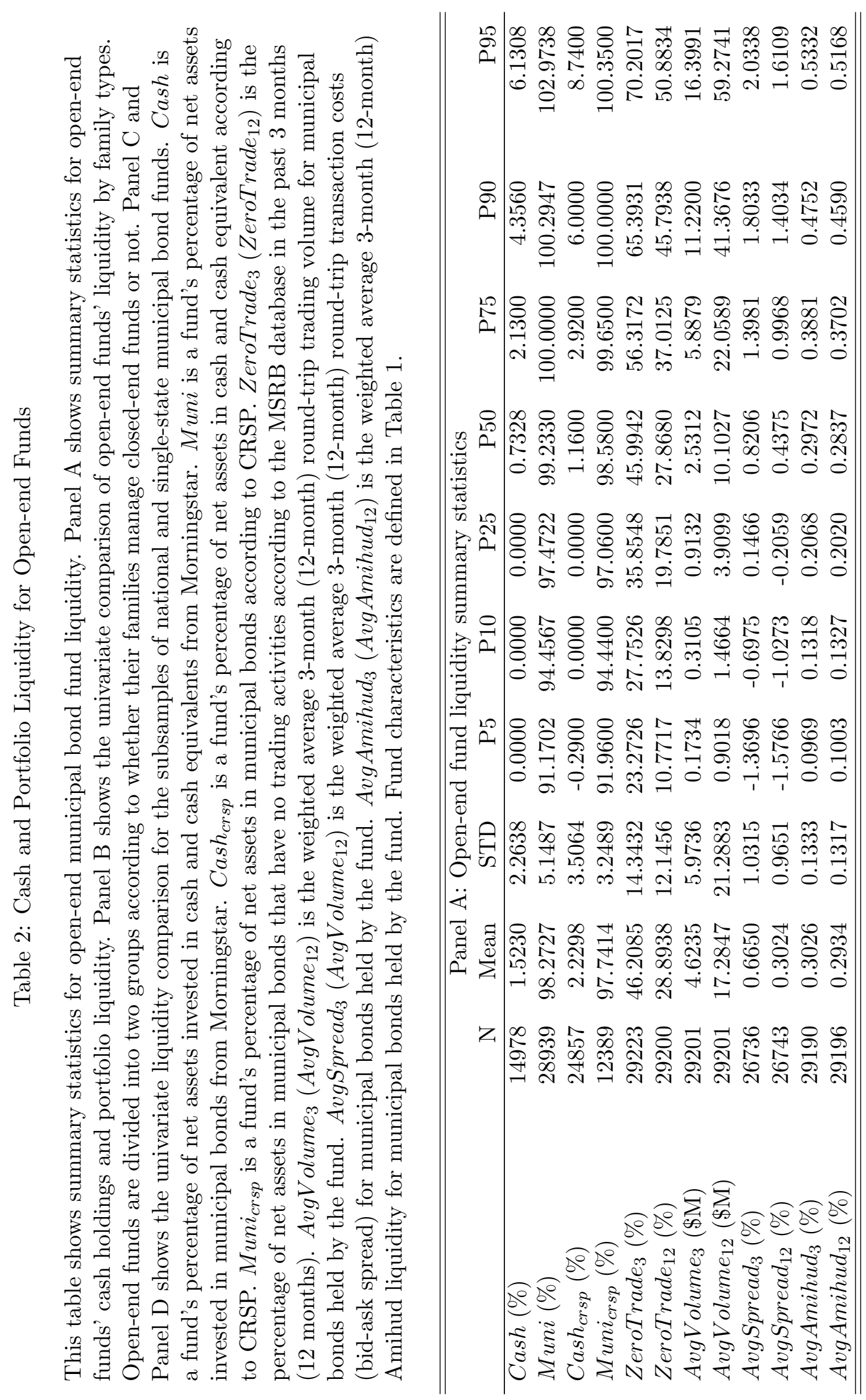




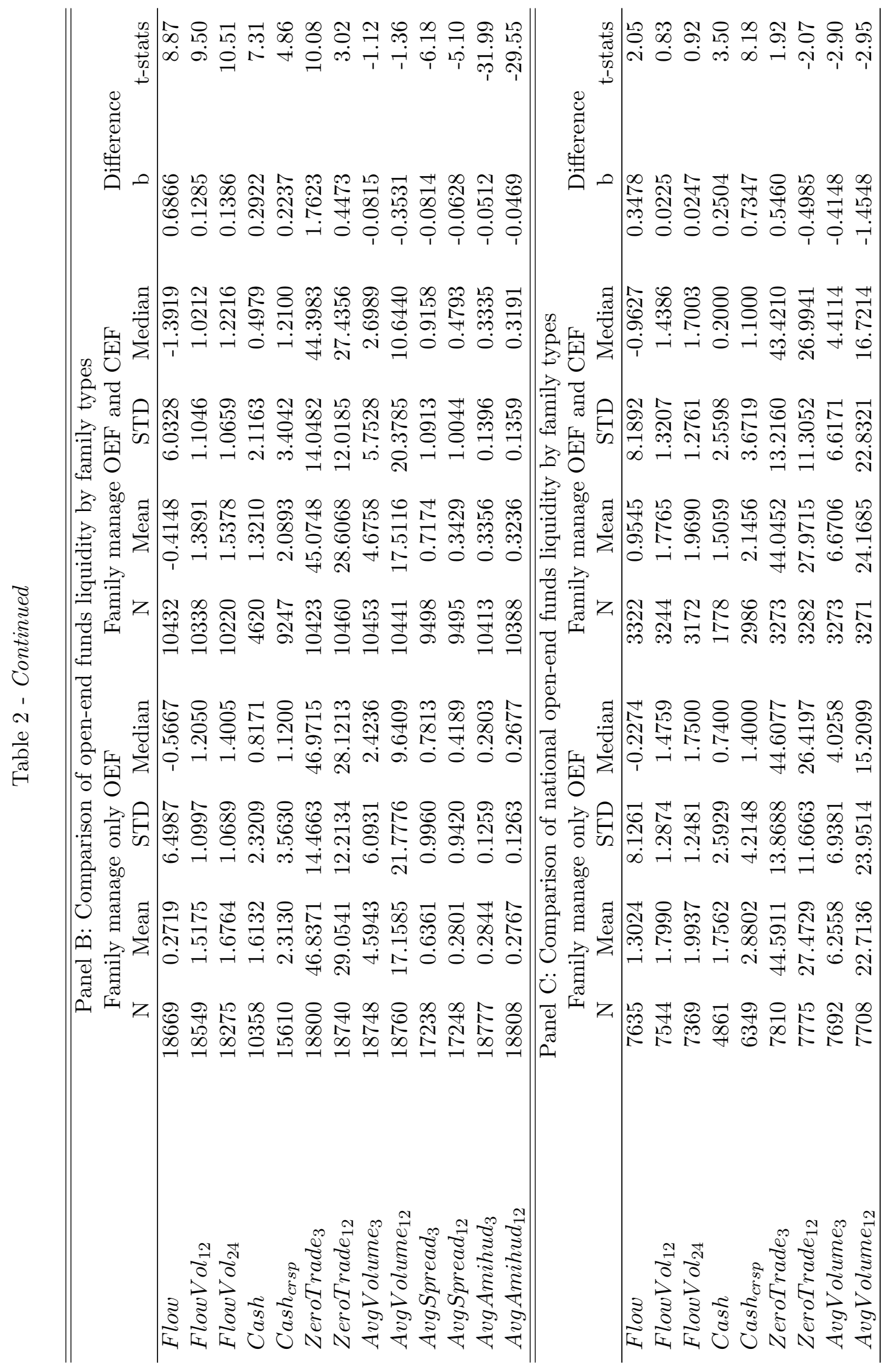




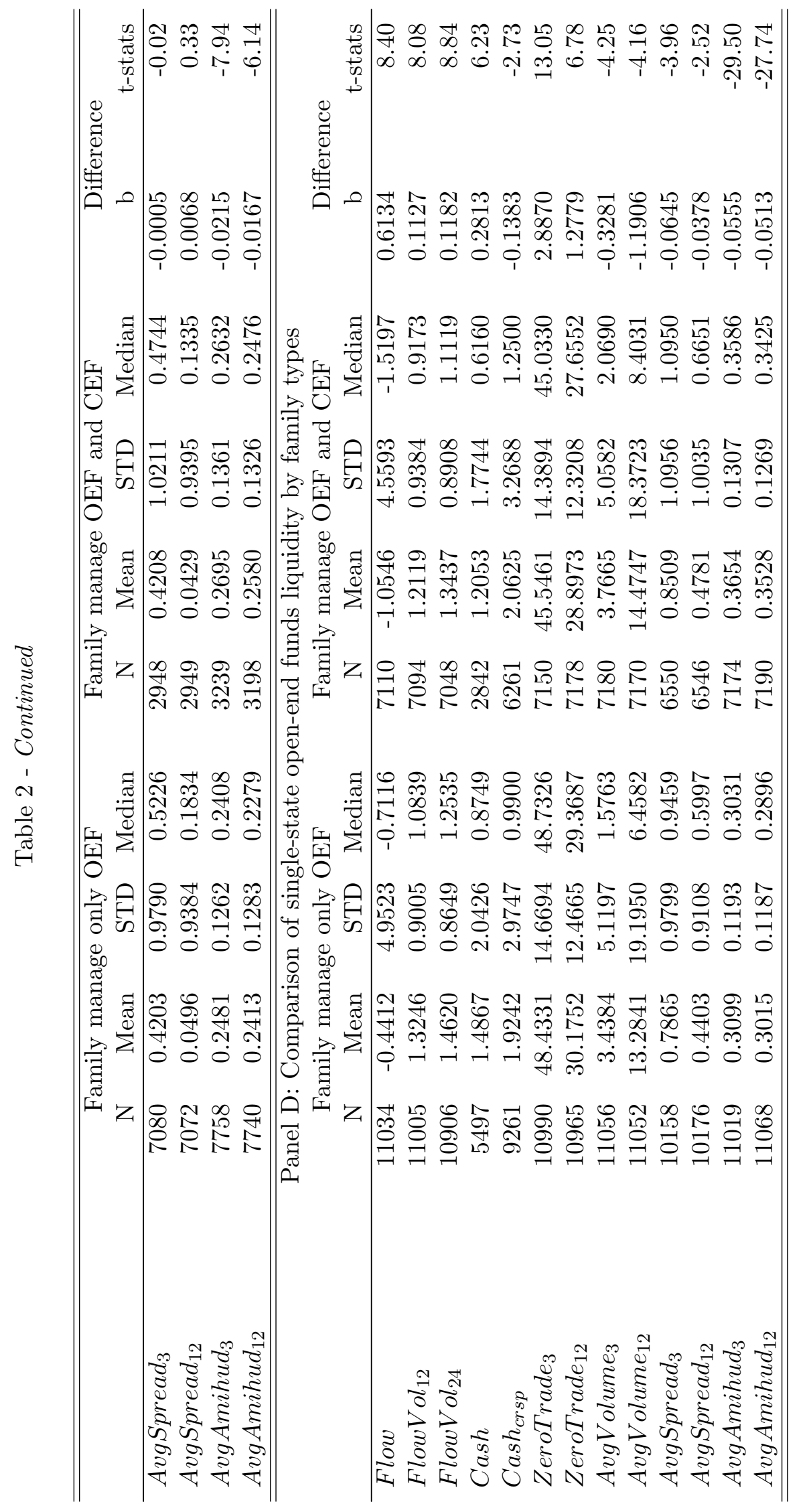


Table 2 Panel $\mathrm{C}$ and Panel D separately show the univariate comparison of cash holding and portfolio liquidity across funds in different types of families for national and single-state funds. National open-end funds across the two types of families have similar past flow volatility. But national open-end funds hold significantly less cash and more illiquid municipal bonds, proxied by high Amihud liquidity, when their fund families also manage closed-end funds. The univariate comparison results are different for single-state funds. Single-state open-end funds have more volatile monthly flows if their fund families only manage open-end funds. They also hold more liquid municipal bonds in their portfolios. The univariate tests show that national and single-state funds behave differently in cash holdings and liquidity management. Therefore, I include a National dummy variable in all multivariate regressions. 


\section{CHAPTER III}

\section{FLOW-PERFORMANCE SENSITIVITY}

I test the flow-performance relationship for municipal bond funds following Sirri and Tufano (1998). I regress funds' quarterly flows on rank of past performance:

$$
\text { Flow }=\alpha+\beta_{1} \text { LowPerf }+\beta_{2} \text { MidPerf }+\beta_{3} H \text { ighPerf }+ \text { controls }
$$

where LowPerf, MidPerf and HighPerf represent the rank of a fund's past 1-year performance. For each investment style and each month, I rank funds' past performance from poorest, with percentile rank as 0 , to best, with percentile rank as 1 . I construct three variables: LowPerf, MidPerf and HighPerf which represent funds with performance in the bottom, the middle three and the top quintile:

$$
\begin{gathered}
\text { LowPerf }=\min (\operatorname{Rank}, 0.2) \\
\text { MidPerf }=\min (0.6, \text { Rank }- \text { LowPerf }) \\
\text { HighPerf }=\text { Rank }- \text { LowPer } f-\text { MidPerf } .
\end{gathered}
$$

By separating funds' performance into quintiles, I can capture the asymmetric responses of investor flows to good and poor past performance.

In addition to the rank regression, I test open-end municipal bond funds' flow-performance relationship following Goldstein, Jiang and Ng (2017):

$$
\text { Flow }=\alpha+\beta_{1} \text { Negative }+\beta_{2} \text { PastPerf }+\beta_{3} \text { Negative } \times \text { PastPer } f+\text { controls },
$$

where Negative is a dummy variable that equals 1 when a fund's past performance is negative and 0 otherwise.

Figure 1, Figure 2, Figure 3 and Figure 4 show the average quarterly and monthly flows for 20 equal groups of open-end funds according to their past performance. The graphs show that municipal bond fund flows are sensitive to past performance and monthly flows are more sensitive to poor past performance than quarterly flows.

Table 3 Panel A shows the flow-performance relationship following Sirri and Tu- 
fano (1998). Using both OLS and Fama-MacBeth regressions, I find the coefficients on LowPerf, MidPerf and HighPerf to be significantly positive, suggesting that investor flows are sensitive to municipal bond funds' past performance.

Table 3 Panel B shows the flow-performance relationship following Goldstein, Jiang and Ng (2017). The coefficients on PastPerf are significantly positive, suggesting that investor flows are sensitive to municipal bond funds' past performance. When I use monthly flows as dependent variable, the coefficients on the interaction between PastPerf and Nagative dummy are significantly positive, suggesting that monthly flows are even more sensitive to poor past performance. For an open-end fund with negative past performance, $1 \%$ decrease in its past performance will lead to $0.44 \%$ outflows per month. Table 3 Panel B also shows the flow-performance relationships for subsamples of national and singlestate funds. The monthly flow-performance relationship in national funds is close to linear. The monthly flow-performance relationship is concave for single-state funds: investor flows respond to both good and poor past performance, but are more sensitive to poor past performance.

The flow-performance relationship documented in Table 3 indicates that municipal bond fund managers are punished for poor performance. Since the municipal bond market has low liquidity, the high flow-performance sensitivity in municipal bond funds motivates fund managers to actively manage fund liquidity. I explore municipal bond funds' liquidity management skills in the following sections. 


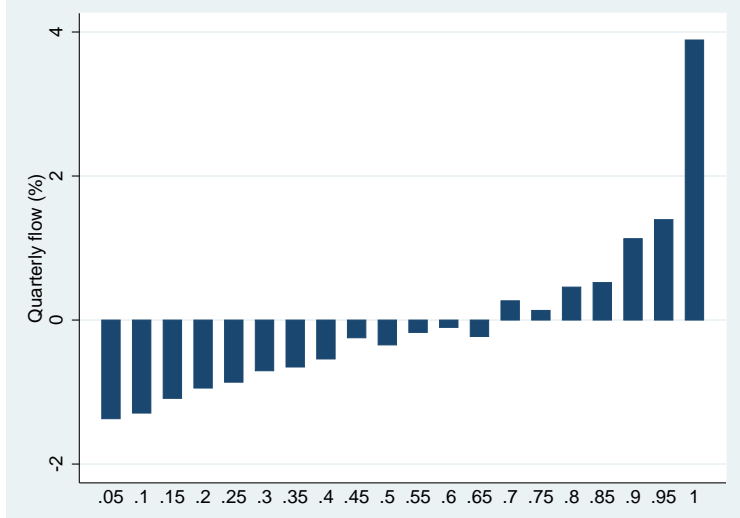

(a) Full Sample

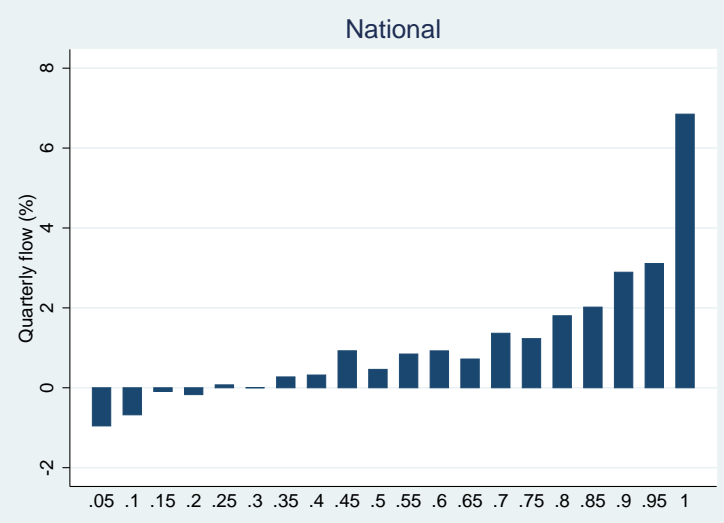

(b) National Open-end Funds

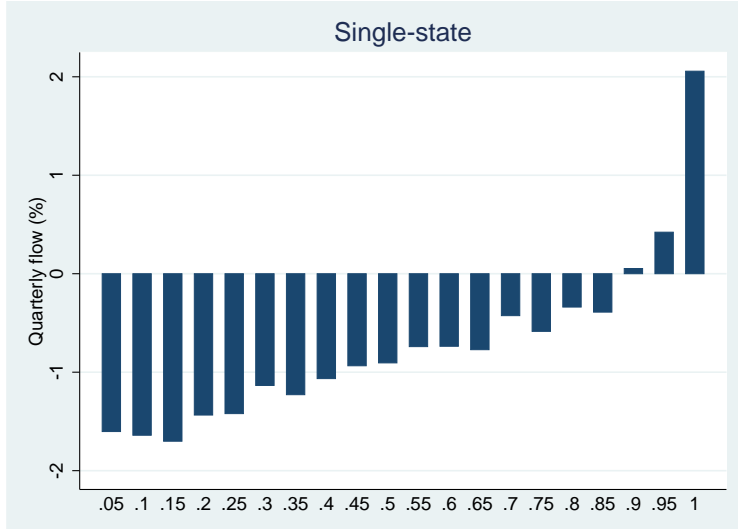

(c) Single-state Open-end Funds

Figure 1: Quarterly Flow-performance Relationship - Rank of Past Performance

This graph shows the average quarterly flows of open-end municipal bond funds as a function of their past performance rankings. For each quarter and investment style, openend funds are divided into 20 equal groups based on their past 1-year performance. For each group, I calculate the average quarterly flows. The $\mathrm{x}$-axis represents performance rankings for these 20 groups from the poorest (ranked as 0 ) to the best (ranked as 1). The y-axis is the mean quarterly flows for each group. 


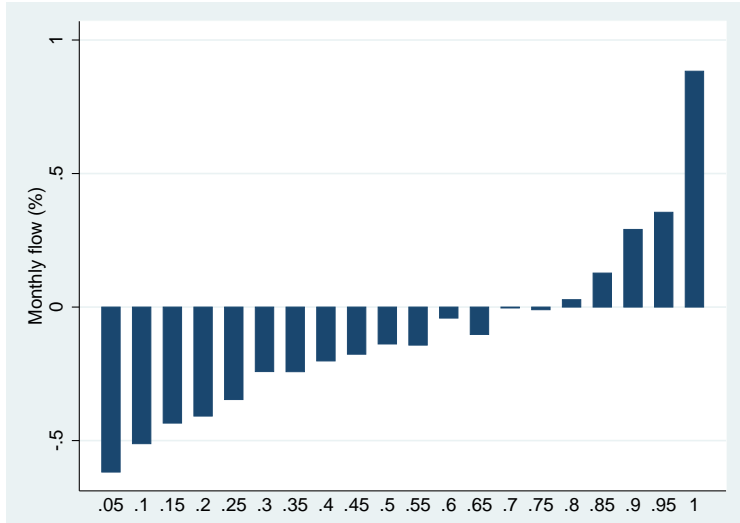

(a) Full Sample

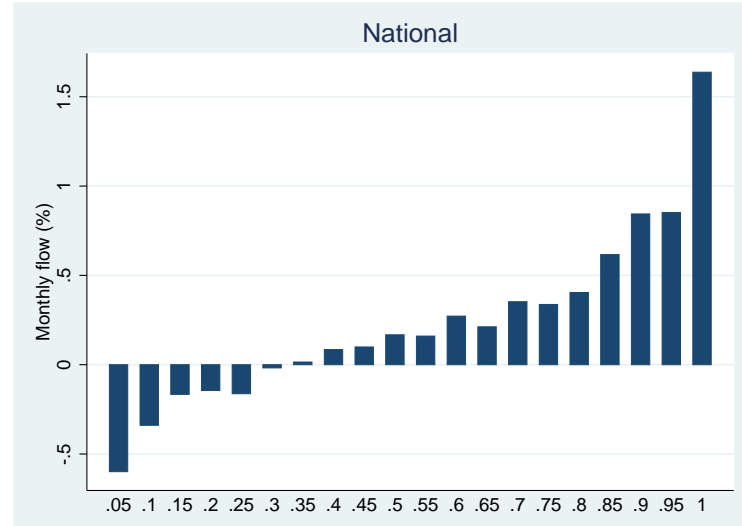

(b) National Open-end Funds

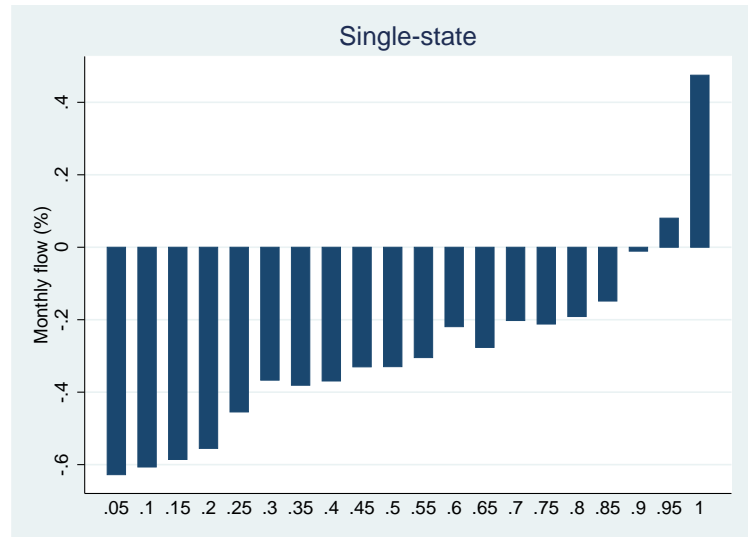

(c) Single-state Open-end Funds

Figure 2: Monthly Flow-performance Relationship - Rank of Past Performance

This graph shows the average quarter flows of open-end municipal bond funds as a function of their past performance rankings. For each month and investment style, open-end funds are divided into 20 equal groups based on their past 1-year performance. For each group, I calculate the average monthly flows. The $\mathrm{x}$-axis represents performance rankings for these 20 groups from the poorest (ranked as 0 ) to the best (ranked as 1). The y-axis is the mean monthly flows for each group. 


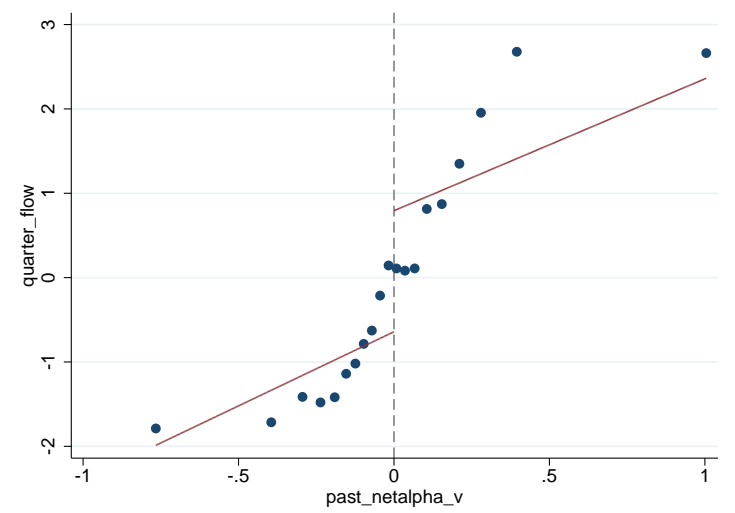

(a) Full Sample

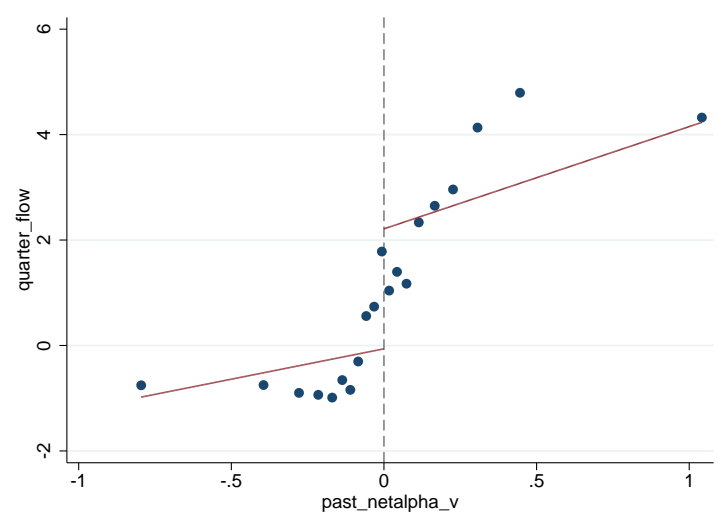

(b) National Open-end Funds

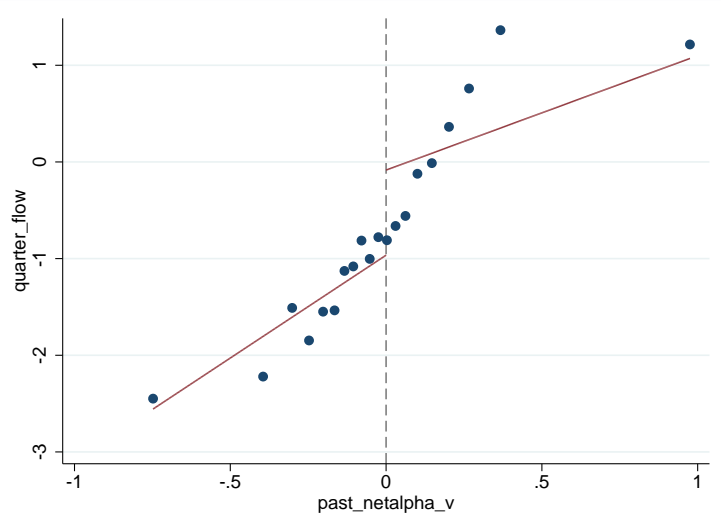

(c) Single-state Open-end Funds

Figure 3: Quarterly Flow-performance Relationship - Past Performance

This graph shows the average quarterly flows of open-end municipal bond funds as a function of their past performance. For each quarter and investment style, open-end funds are divided into 20 equal groups based on their past 1-year performance. For each group, I calculate the average quarterly flows. The x-axis represents average past performance for these 20 groups. The y-axis is the mean quarterly flows for each group. 


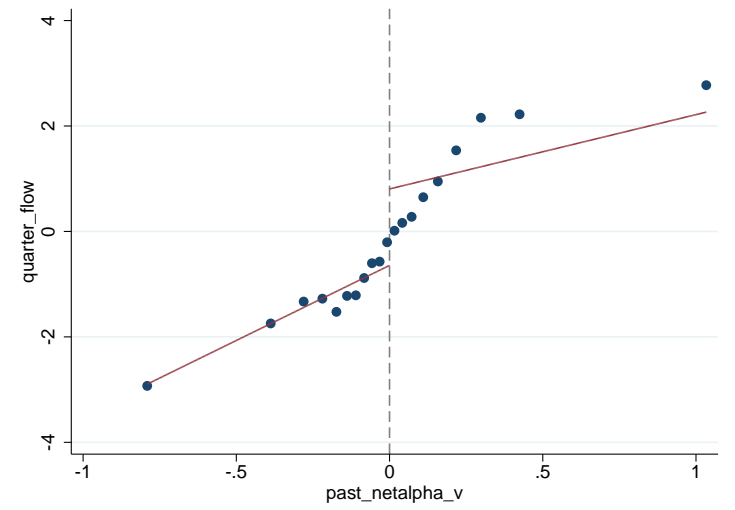

(a) Full Sample

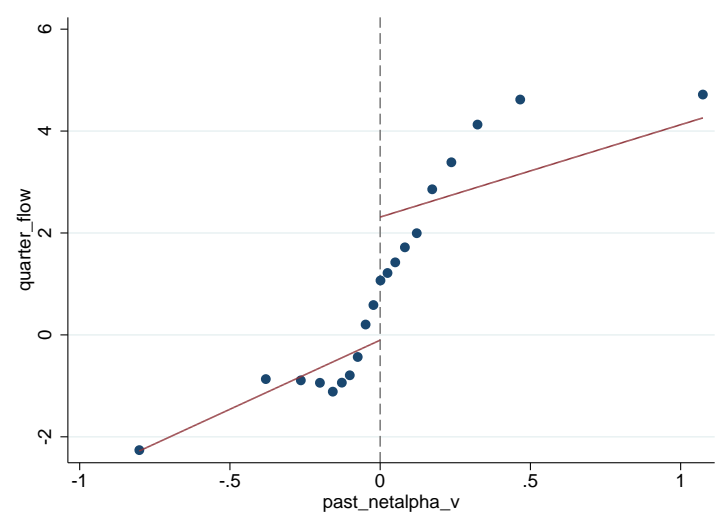

(b) National Open-end Funds

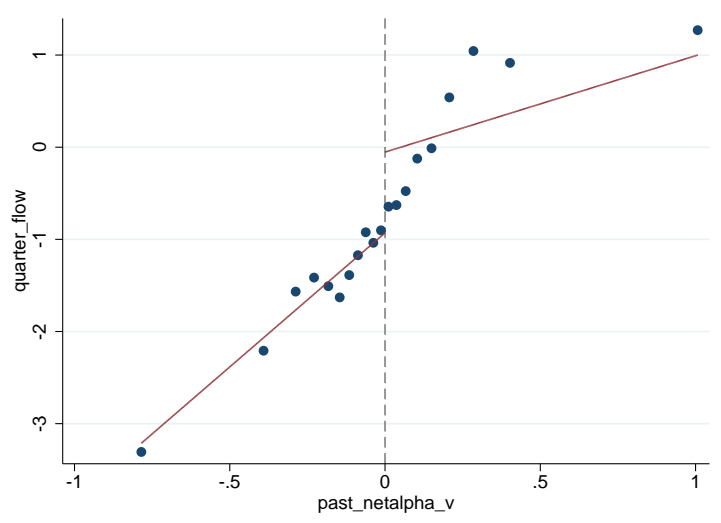

(c) Single-state Open-end Funds

Figure 4: Monthly Flow-performance Relationship - Past Performance

This graph shows the average quarter flows of open-end municipal bond funds as a function of their past performance rankings. For each month and investment style, open-end funds are divided into 20 equal groups based on their past 1-year performance. For each group, I calculate the average monthly flows. The $\mathrm{x}$-axis represents average past performance for these 20 groups. The y-axis is the mean monthly flows for each group. 


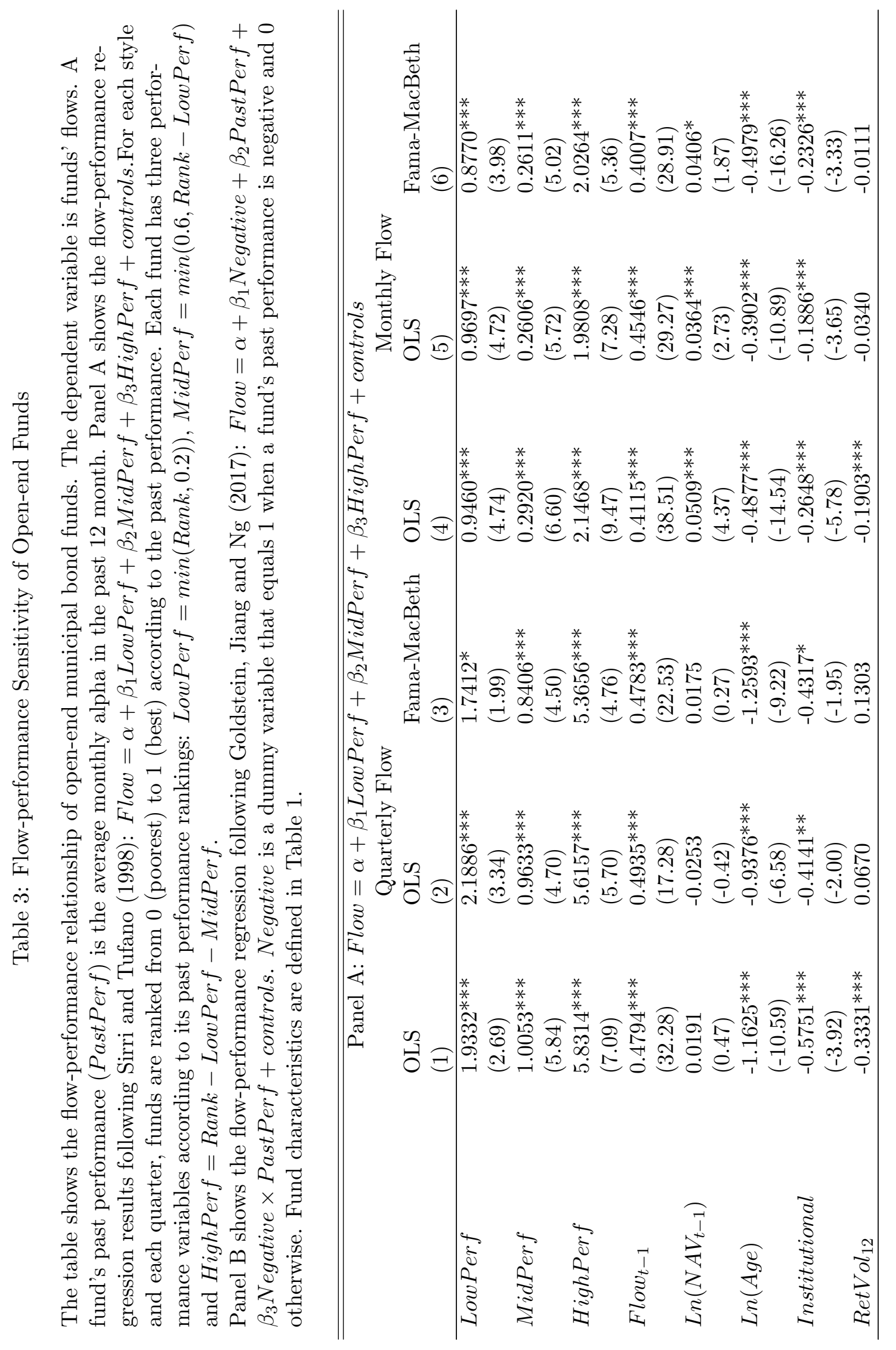




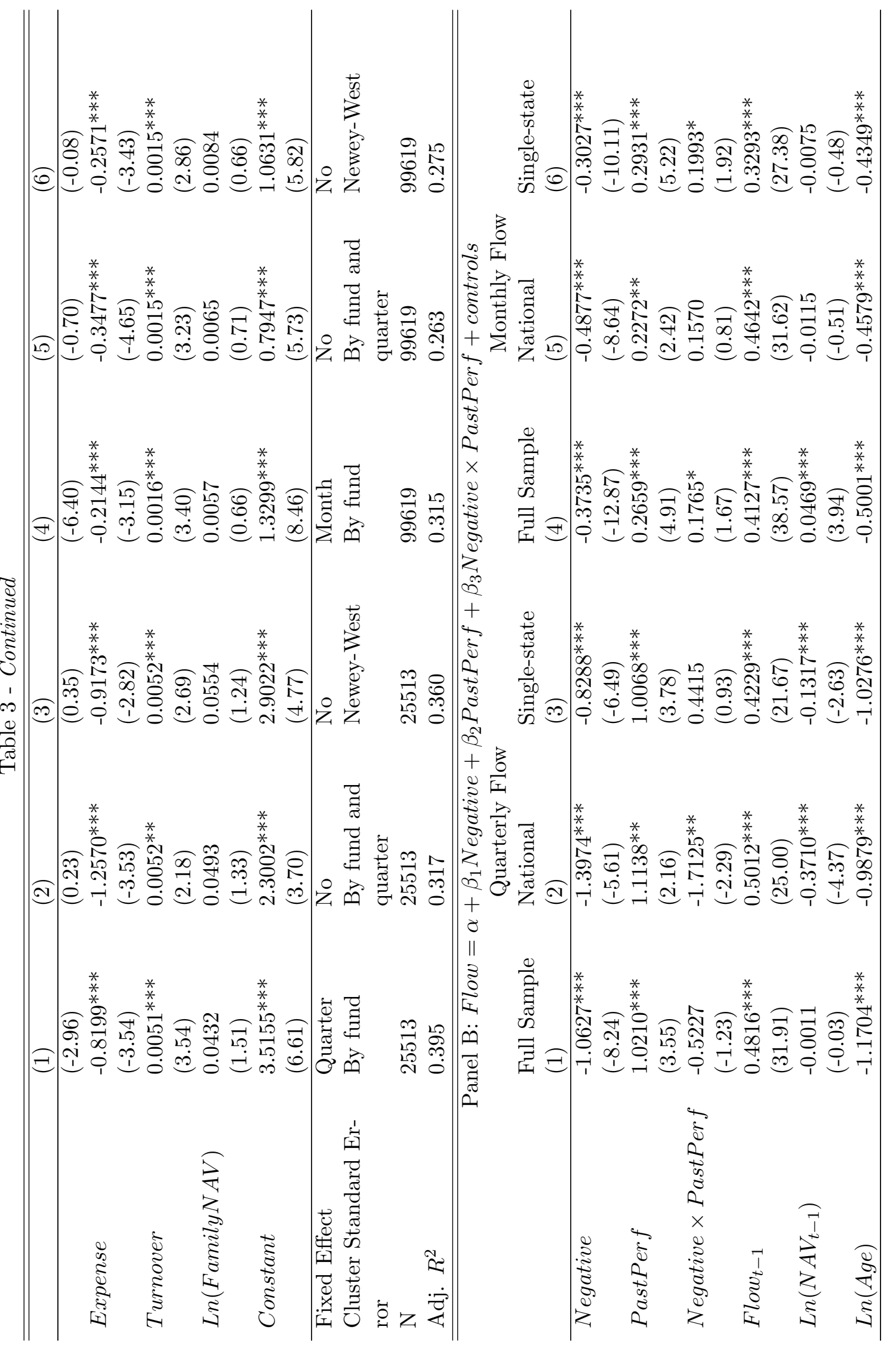




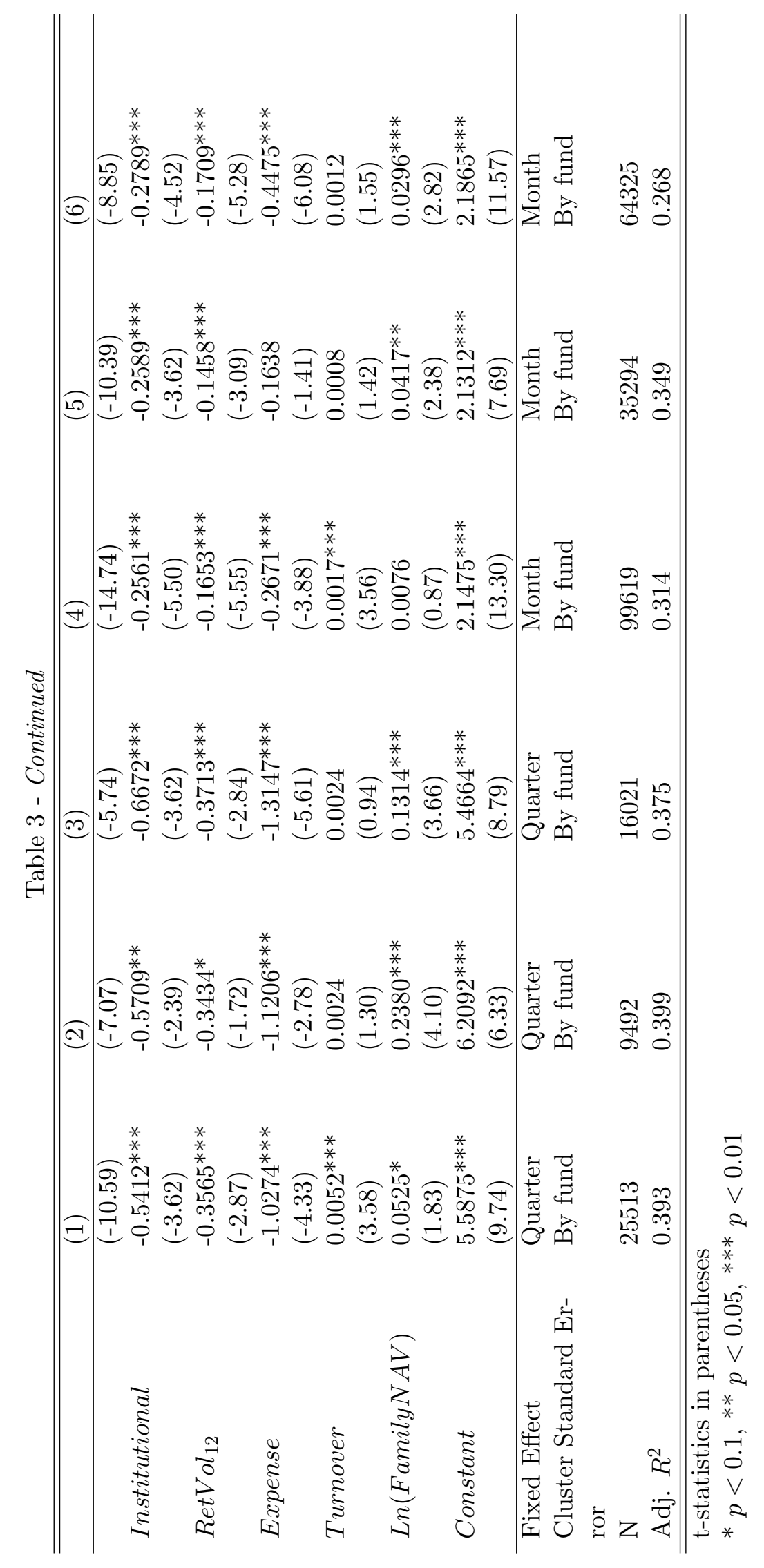




\section{CHAPTER IV}

\section{LIQUIDITY MANAGEMENT}

\subsection{Cash Holding and Flow Management}

Table 4 Panel A shows the relationship between open-end municipal bond funds' cash position and their past flow volatility:

$$
\text { Cash }=\alpha+\beta \text { Flow }_{\text {Vol }}+2+\gamma \text { PortLiquidityt }-1+\text { Controls } .
$$

The coefficient $\beta$ is significantly positive, suggesting that fund managers hold more cash when the fund has higher liquidity risk, measured by flow volatility in the past 12 months ${ }^{13}$. When an open-end funds' flow volatility increase by $1 \%$, the fund will hold additional $0.22 \%$ of its net assets in cash and cash equivalents. Cash holding is negatively associated with fund size and positively associated with institutional share. Cash holding is negatively associated with family size. Open-end funds in large fund families hold less cash, suggesting economies of scale in liquidity management at family level. The coefficients on Family ${ }_{O E F, C E F}$ is insignificant, suggesting that whether the fund families manage closed-end funds or not does not affect open-end funds' cash holdings. I also find modest evidence that a fund's cash position is associated with its portfolio liquidity. Cash holding is negatively associated with AvgVolume and positively associated with AvgSpread, suggesting that open-end funds hold more cash when they hold more illiquid municipal bonds.

Table 4 Panel B studies how open-end municipal bond funds use cash in flow management. In column (1) to (4), I regress cash position changes on concurrent quarterly flows:

$$
\Delta \text { Cash }=\alpha+\beta \text { Flow }+ \text { Controls }
$$

$\Delta$ Cash $=\alpha+\beta_{1}$ LargeOutflow $+\beta_{2}$ Outflow $+\beta_{3}$ Inflow $+\beta_{4}$ LargeInflow + Controls

\footnotetext{
${ }^{13}$ In untabulated tests, I regress the cash holdings and portfolio liquidity of open-end funds on their flow volatility in the past 24 months, FlowVol 24 . The regression results are similar.
} 


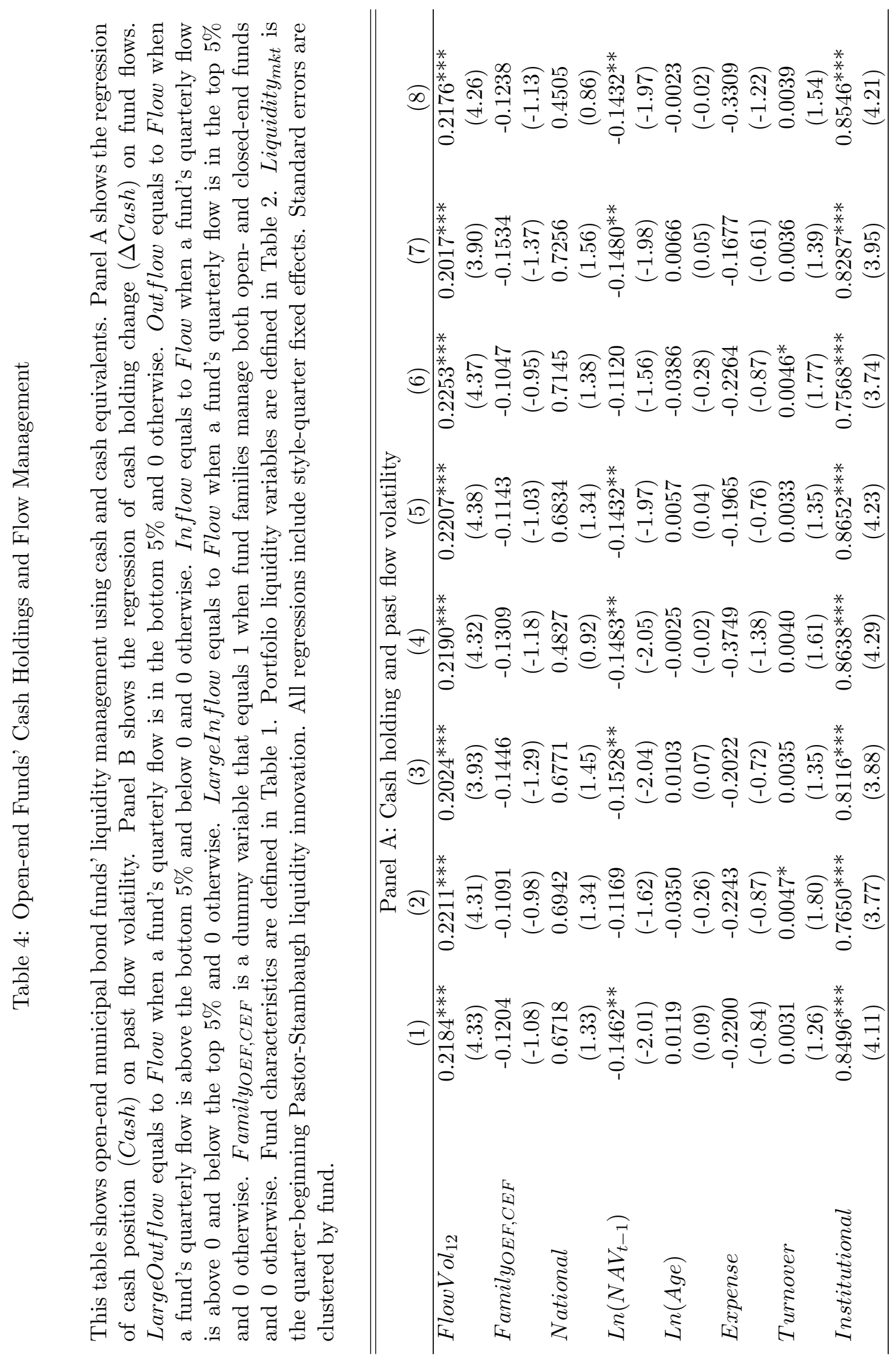




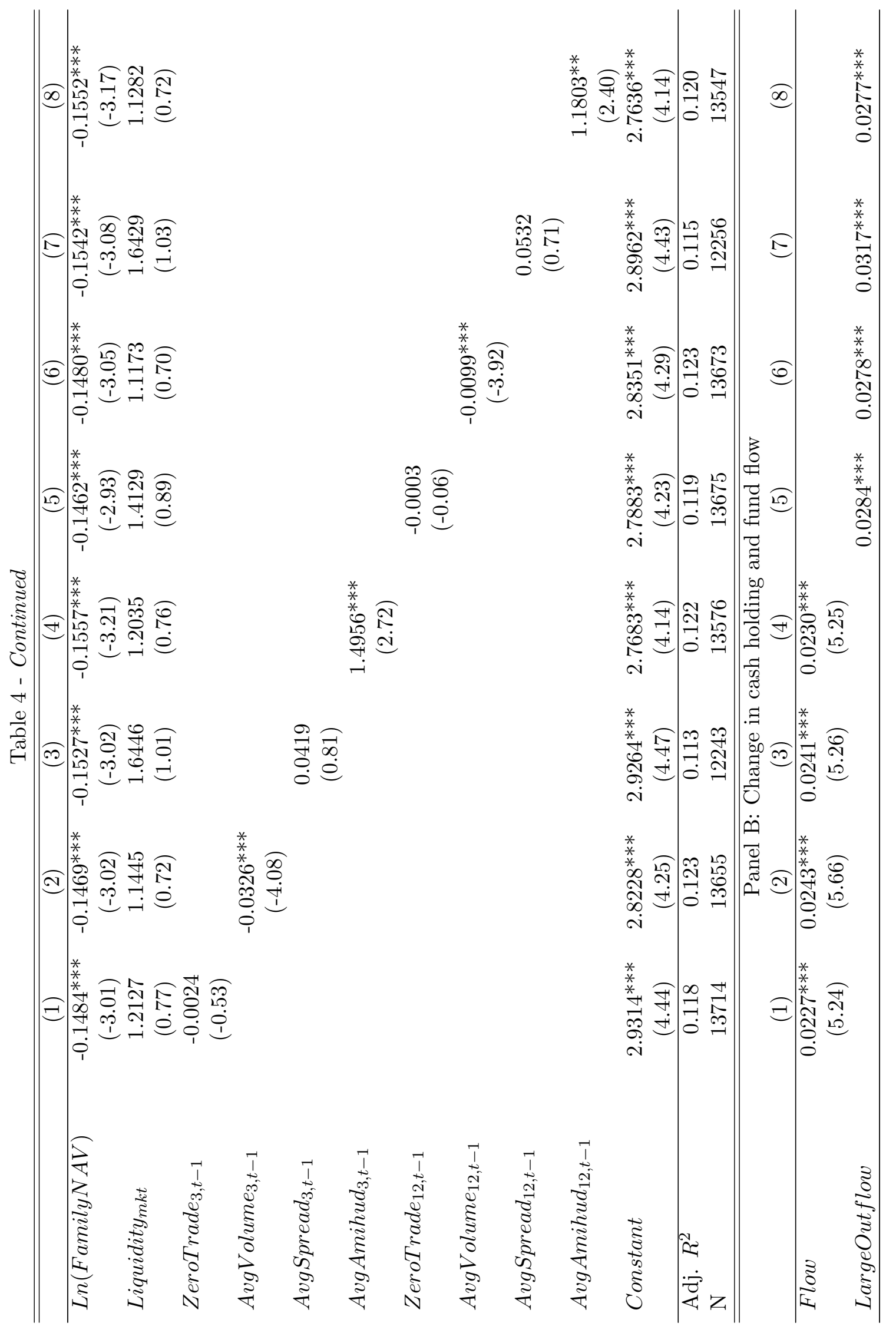




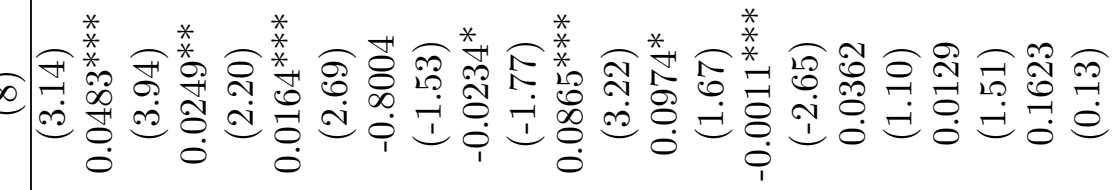

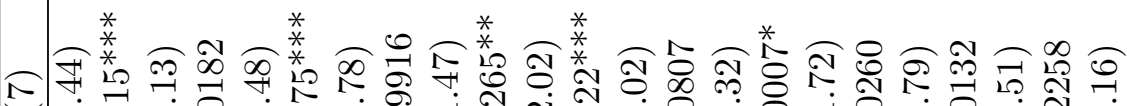

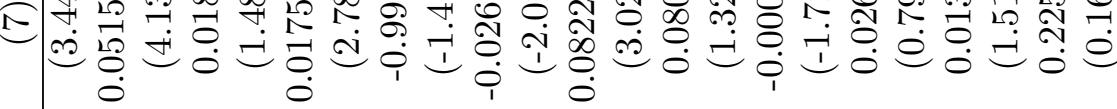

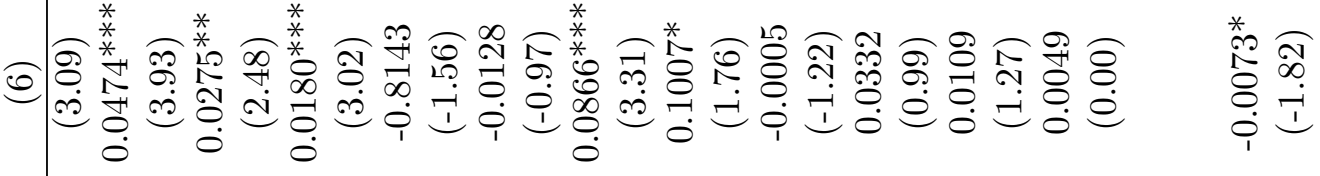

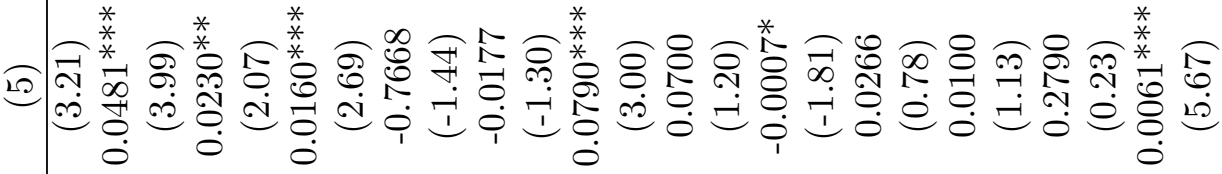

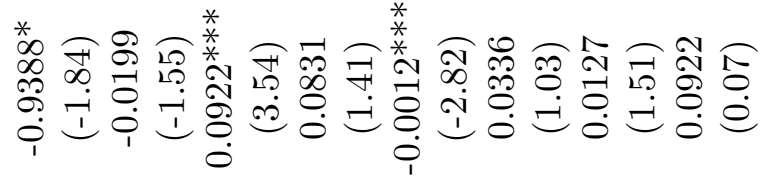

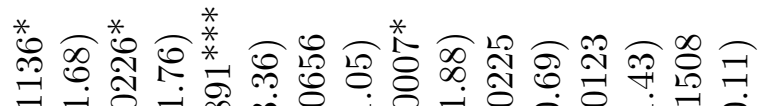

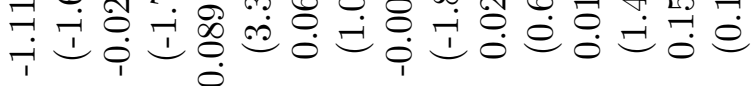

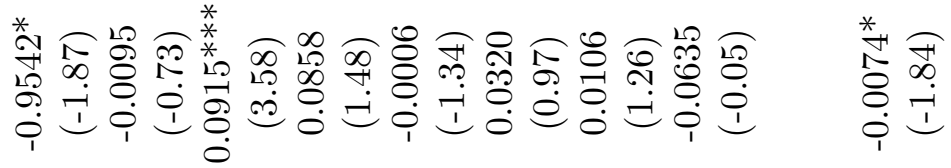

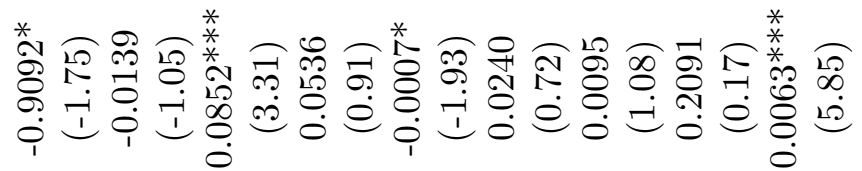

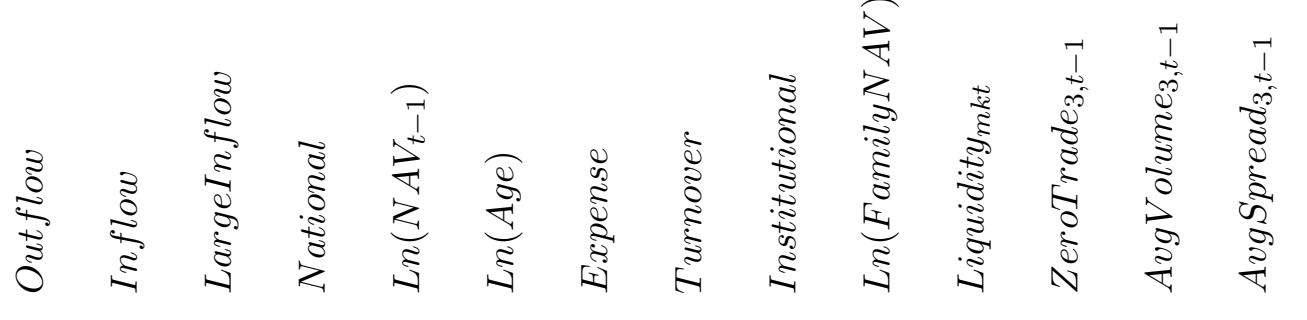




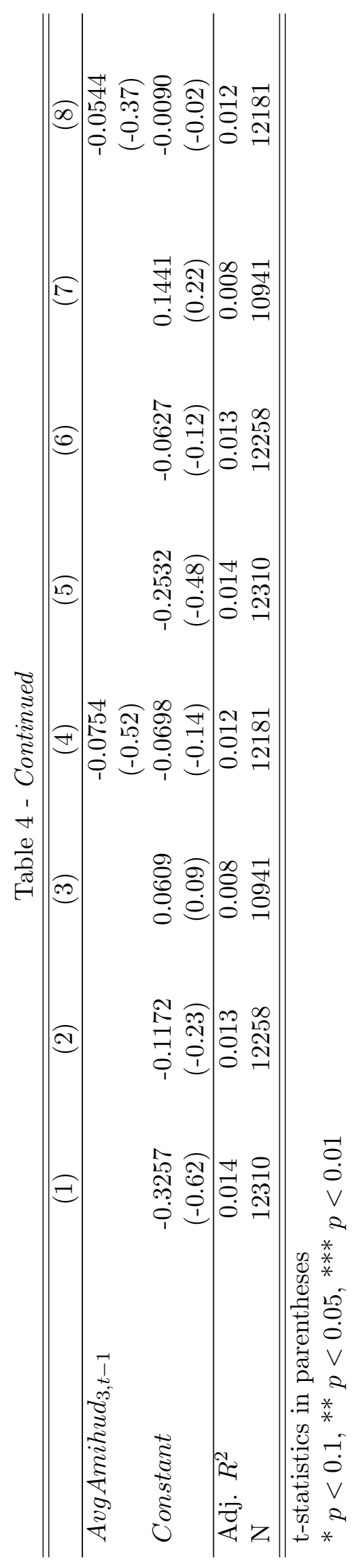


If fund managers proportionally liquidate holdings to meet investor redemptions, beta will be close to 0 . If fund managers use cash to accommodate inflows and outflows, $\beta$ will be positive. The coefficient $\beta$ is significantly positive, suggesting that fund managers use cash to accommodate investor flows and avoid flow-driven transactions. Open-end funds with inflows (outflows) that equal to $100 \%$ of their net assets increase (decrease) their cash positions by $2.4 \%$.

Column (5) to (8) in Table 4 Panel B show the piece-wise regression results. LargeOutflow and LargeInflow equal to Flow when a fund's quarterly flow is in the bottom or top $5 \%$ and 0 otherwise. Outflow and Inflow equal to Flow when a fund's quarterly flow is between 0 and the bottom or top 5th percentile and 0 otherwise. The piece-wise regression results are consistent with the OLS regression results. Fund managers use cash holdings to accommodate investor flows and they do not behave differently across inflows and outflows. I find modest evidence that open-end funds use less cash at extreme flows. The coefficient on LargeOutflow $\left(\beta_{1}=0.028\right)$ is lower than the coefficient on Outflow $\left(\beta_{2}=0.048\right)$ with p-value close to $10 \%$. Distressed open-end funds can experience outflows larger than $7.77 \%$, but the average municipal bond funds only hold less than $2 \%$ net assets in cash. Since the low cash holdings are not enough to meet large investor redemptions, I expect that open-end funds use unconventional liquidity management tools when they experience large outflows.

\subsection{Portfolio Liquidity and Flow Management}

Table 5 Panel A shows the relationship between a fund's portfolio liquidity and its past flow volatility. I find evidence that the monthly flow volatility of open-end municipal bond funds is positively associated with the average trading volume and is negatively associated with the average bid-ask spread and Amihud liquidity of municipal bonds in their portfolios, suggesting that funds with higher liquidity risk hold more liquid munici-

pal bonds. When an open-end fund's flow volatility increases by $1 \%$, the average trading volume increases by 1.52 million, the average bid-ask spread decreases by 2.3 basis points 
and the average Amihud price impact decrease by 0.5 basis point. The portfolio liquidity of open-end funds is also related to fund characteristics. Portfolio liquidity is positively associated with fund size and turnover ratio and is negatively associated with fund age and expense ratio.

Table 5 Panel B shows the relationship between change in portfolio liquidity and concurrent flows. A fund's quarterly flow is positively associated with change in its portfolio's average trading volume. A fund with 100\% quarterly inflow (outflow) increases (decreases) the average trading volume of its municipal bond holdings by 5.78 million - 16.7 million. A fund's quarterly flow is negatively associated with change in the zerotrade municipal bond weight, average bid-ask spread and Amihud liquidity. A fund that experience $100 \%$ inflow (outflow) in a quarter decreases (increases) the holding in zerotrading municipal bonds by $1.75 \%$ - 6.61\%. A fund that experience $100 \%$ inflow (outflow) in a quarter decreases (increases) its portfolio's average bid-ask spread by $27-47$ basis points and average Amihud liquidity by $0.04 \%$ - 0.05\%. There results provide evidence that open-end funds use more liquid municipal bonds to accommodate investor flows. This finding is consistent with the previous literature in corporate bond fund liquidity management. For example, Jiang, Li and Wang (2016) find that corporate bond mutual funds sell relatively liquid corporate bonds first to fulfill investor redemptions. Manconi, Massa and Yasuda (2012) find that mutual funds with the most negative flows significantly reduce relatively liquid corporate bond holdings but retain illiquid securitized bonds during the 2007-2008 financial crisis.

Table 5 Panel $\mathrm{C}$ shows the piece-wise regression of portfolio liquidity change on fund flows. The coefficients on the flow variables are statistically significant and consistent with the results in Panel B. The coefficient on LargeOutflow is statistically similar to that on Outflow, suggesting that open-end municipal bond funds respond to modest flows and extreme flows in the same way in portfolio liquidity management. 


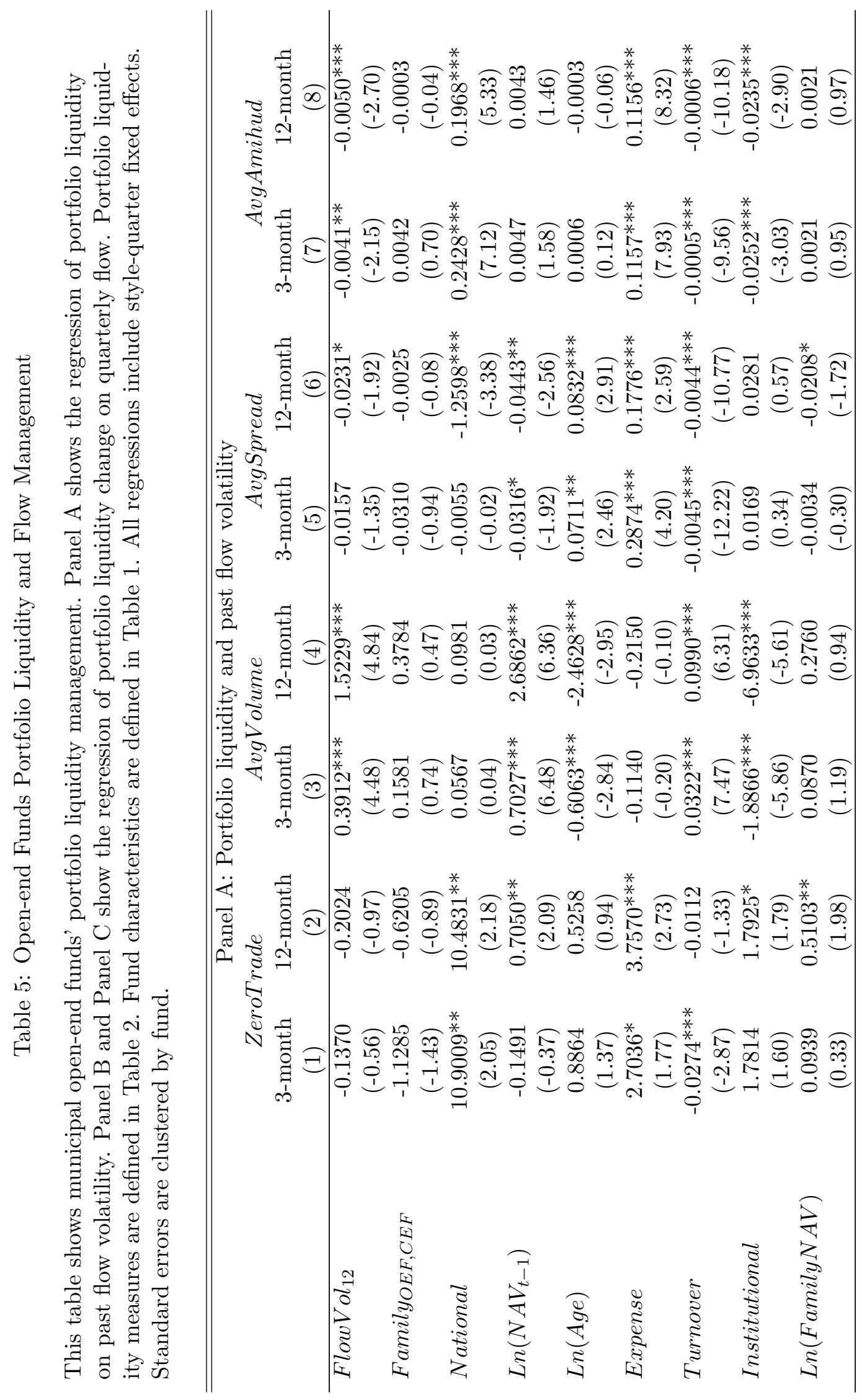




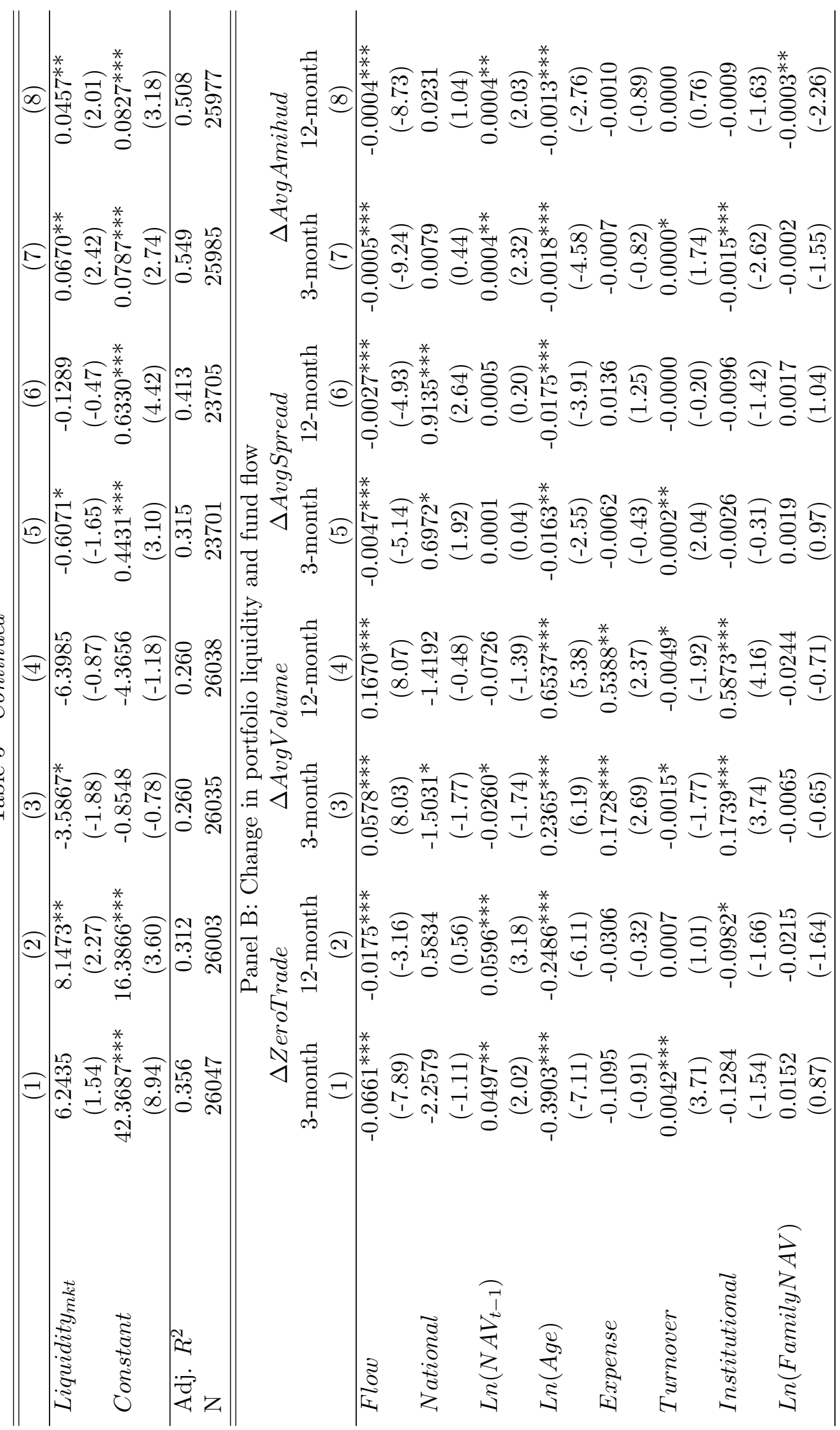




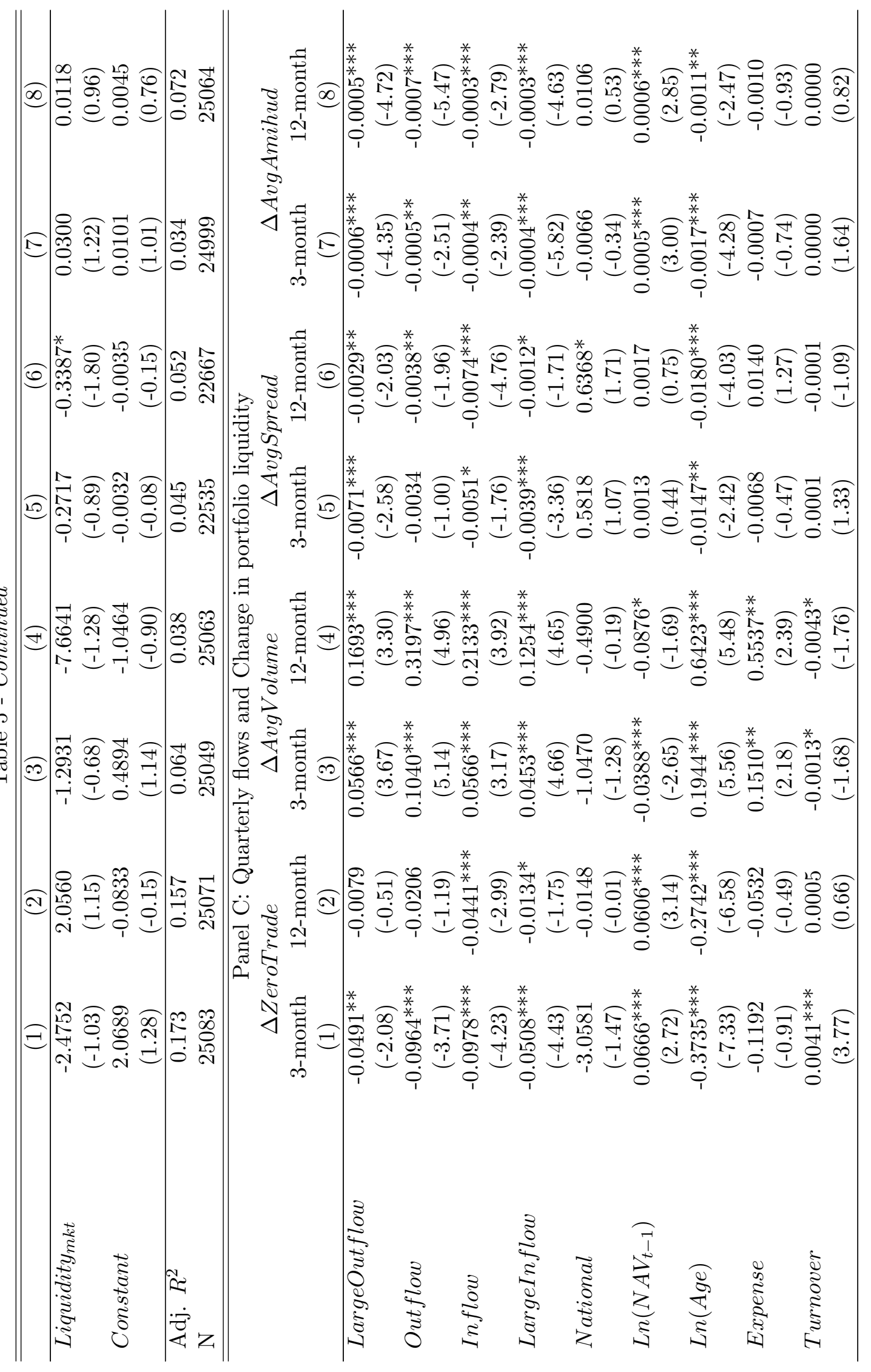




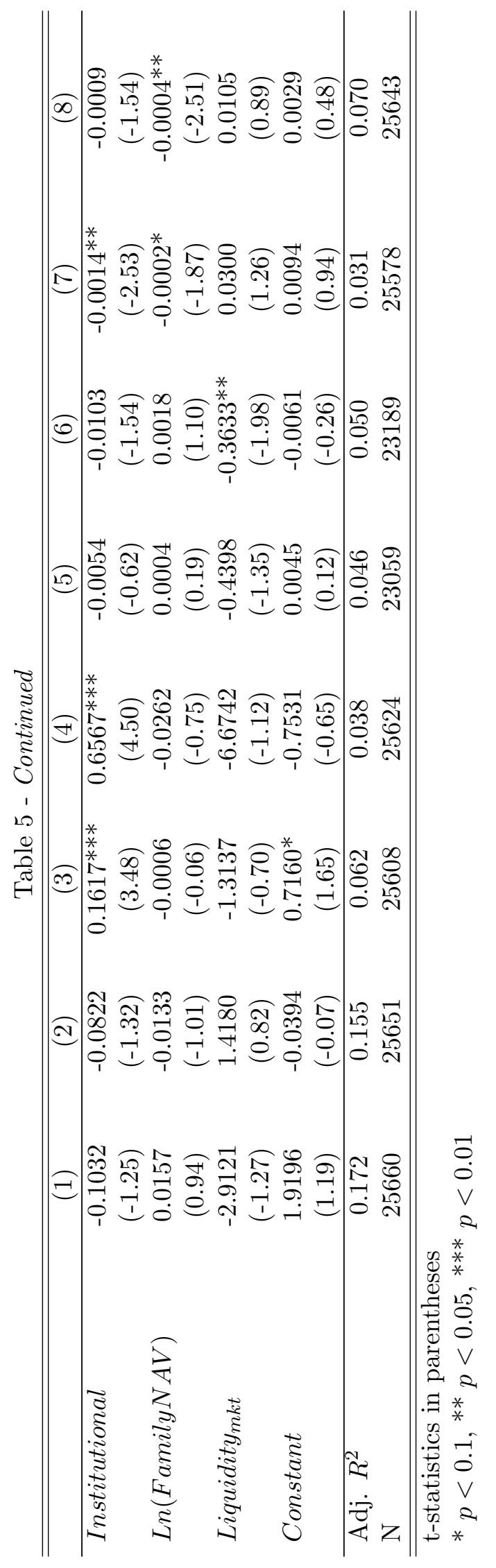


Table 4 and Table 5 provide evidence of active liquidity management in open-end municipal bond funds. I find evidence that open-end funds build liquidity buffers when they have high funding liquidity risk. I also find that open-end funds use cash and liquid securities to accommodate inflows and outflows in order to reduce the costs of flow-driven transactions. I find modest evidence that fund rely less on cash management in extreme outflows. I expect that open-end funds do not have enough cash to meet large investor redemptions. Therefore, they use unconventional liquidity management tools when they are in distress. In the next section, I explore the unconventional liquidity management tool, namely cross-trading with funds in the same family. 


\section{CHAPTER V}

\section{CROSS-TRADING AND LIQUIDITY MANAGEMENT}

\subsection{Measure of Cross-trading and Matched-sample Methodology}

Since investment funds are not required to publicly disclose any cross-trades conducted in the family internal market, the sizes and prices of cross-trades are not observable. A common method in the cross-subsidization literature is to use offsetting holding changes between two funds as estimations of cross-trades. I follow Gaspar, Massa and Matos (2006) and Chuprinin, Massa and Schumacher (2015) to construct cross-trading variables and to test the relationship between fund flows and cross-trading between open- and closed-end funds.

I use a matched-sample methodology to test whether open-end funds cross-trade with affiliated closed-end funds. I look at the offsetting holding changes between openand closed-end funds in the same family, as well as the offsetting holding changes between open- and closed-end funds that belong to different families. If family strategies exist in cross-trading activities, I expect that the offsetting holding changes between open- and closed-end funds in the same family are significantly larger than those between openand closed-end funds belonging to different families. Moreover, if fund families use crosstrading in liquidity management, I expect that the offsetting holding changes between open- and affiliated closed-end funds are associated with open-end fund flows.

For each open-end fund $j$ in family $F, \mathrm{I}$ assume that it can cross-trade with the set $J$ of affiliated closed-end funds that belong to the same family $F$. I also assume that it can cross-trade with the set $J$ of unaffiliated closed-end funds that do not belong to family $F$. The pair of open and affiliated closed-end funds is called actual pair. The pair of open- and unaffiliated closed-end funds is called matched pair.

For each open- and closed-end fund pair $j-J$, I consider all the municipal bonds that are sold by open-end fund $j$ and simultaneously bought by closed-end fund $J$. By 
looking at such offsetting holding changes ${ }^{14}$, I estimate the largest possible number of municipal bond shares that could have been traded between the pair of funds. The upper bound of cross-trading shares is the minimum between the number of shares sold by open-end fund $j$ and bought by closed-end fund $J$. I multiply this number by the price of municipal bonds at the beginning of the quarter to estimate cross-trading volume, scaled by the total NAV of the pair of funds. This variable measures cross-sale from open-end fund $j$ to closed-end fund set $J$ :

$$
\operatorname{CrossSale~}_{j, J, t}=\sum_{i} \frac{P_{i, t-1} \times \min \left(S_{j, i, t}, B_{J, i, t}\right)}{N A V_{j, t-1}+N A V_{J, t-1}},
$$

where $S_{j, i, t}$ is the shares of municipal bond $i$ sold by open-end fund $j$ in quarter $t$, and $B_{J, i, t}$ is the shares of municipal bond $i$ bought by closed-end fund $J$ in quarter $t . P_{i, t-1}$ is the price of municipal bond $i$ at the beginning of quarter $t^{15}$.

Similarly, I construct a variable that estimates open-end fund $j^{\prime} s$ cross-buy from closed-end fund $J$ :

$$
\operatorname{CrossBuyj,J,t}_{j}=\sum_{i} \frac{P_{i, t-1} \times \min \left(B_{j, i, t}, S_{J, i, t}\right)}{N A V_{j, t-1}+N A V_{J, t-1}}
$$

I also construct total cross-trade and net cross-trade variables as follows:

$$
\begin{gathered}
\text { CrossTrade }_{j, J, t}=\text { CrossSale }_{j, J, t}+\text { CrossBuy }_{j, J, t} \\
\text { NetCrossSale }_{j, J, t}=\text { CrossSale }_{j, J, t}-\text { CrossBuyj,J,t }_{j}
\end{gathered}
$$

At last, I construct CrossTradeTurnover as the dollar value of cross-trades scaled by the NAV of open-end fund $j: \sum \frac{P \times \min \left(S_{j}, B_{J}\right)+P \times \min \left(B_{j}, S_{J}\right)}{N A V_{j, t-1}}$.

Table 6 shows summary statistics for cross-trading between open- and closed-end

\footnotetext{
${ }^{14}$ One concern in using holding data to estimate cross-trading is that funds have different financial year-end dates and portfolio dates. When two funds have different portfolio dates in a quarter, offsetting holding changes are less likely to be cross-trades. $94.58 \%$ of open-end fund quarterly portfolios and $74.7 \%$ of closed-end fund quarterly portfolios in my sample have portfolio dates the same as calendar quarter-end dates. Since the majority fund report their portfolios at the end of March, June, September and December, mismatch of holding periods should not be a major concern.

${ }^{15}$ Municipal bonds are not traded in a centralized market. Therefore, the month-end price is not publicly available. I use MSRB municipal bond trading data and Morningstar municipal bond fund holding data to estimate month-end bond prices. See Appendix A for the detail description of municipal bond price estimation process.
} 
funds for actual and matched pairs. The sample consists of 345 open-end funds in the 23 families that manage both open- and closed-end funds. I construct 9047 actual crosstrading pairs and the same amount of matched pairs ${ }^{16} .1183$ (780) actual pairs have nonzero CrossSale (CrossBuy) variable, and 2094 (1551) matched pairs have non-zero CrossSale (CrossBuy) variable. The cross-trading variables in actual $j-J$ pairs are significantly larger than those in matched pairs. The average value of CrossSale (CrossBuy) is $7.11 \%$ (6.49\%) of the aggregated net assets for the actual cross-trading pairs, but only $0.75 \%$ $(0.75 \%)$ for the matched cross-trading pairs. The actual pairs' closed-end fund sets $J$, on average, have 22 closed-end funds and 5764 million in aggregate net assets. The matched pairs' closed-end fund sets have 172 closed-end funds and 44822 million net assets. The univariate comparison shows that open-end funds have more offsetting holding changes with affiliated closed-end funds than with unaffiliated closed-end funds. However, it seems that a part of the difference is driven by the fact that the aggregate set of unaffiliated closed-end funds is larger than that of affiliated closed-end funds. In the multivariate analysis, I control for the size of closed-end fund set $J$.

\subsection{Fund Flows and Cross-trading between Open- and Closed-end Funds}

I run the following regressions to test whether fund families coordinate cross-trades between open- and closed-end funds to provide liquidity to distressed open-end funds:

$$
\text { Crosstrade }_{j, J}=\alpha+\beta_{1} \text { Affiliated }_{j, J}+\beta_{2} \text { Flow }_{j}+\beta_{3} \text { Affiliated }_{j, J} \times \text { Flow }_{j}+\text { Controls }
$$

where Affiliated is a dummy variable that equals 1 for actual pairs and 0 for matched pairs. I use CrossTradeTurnover to control for generic difference in funds' trading behavior. I use $\operatorname{Ln}\left(N A V_{J}\right)$ to control for the quantity of available cross-trading closed-end funds.

\footnotetext{
${ }^{16}$ I drop 10 observations with cross-trading variables larger than $100 \%$.
} 


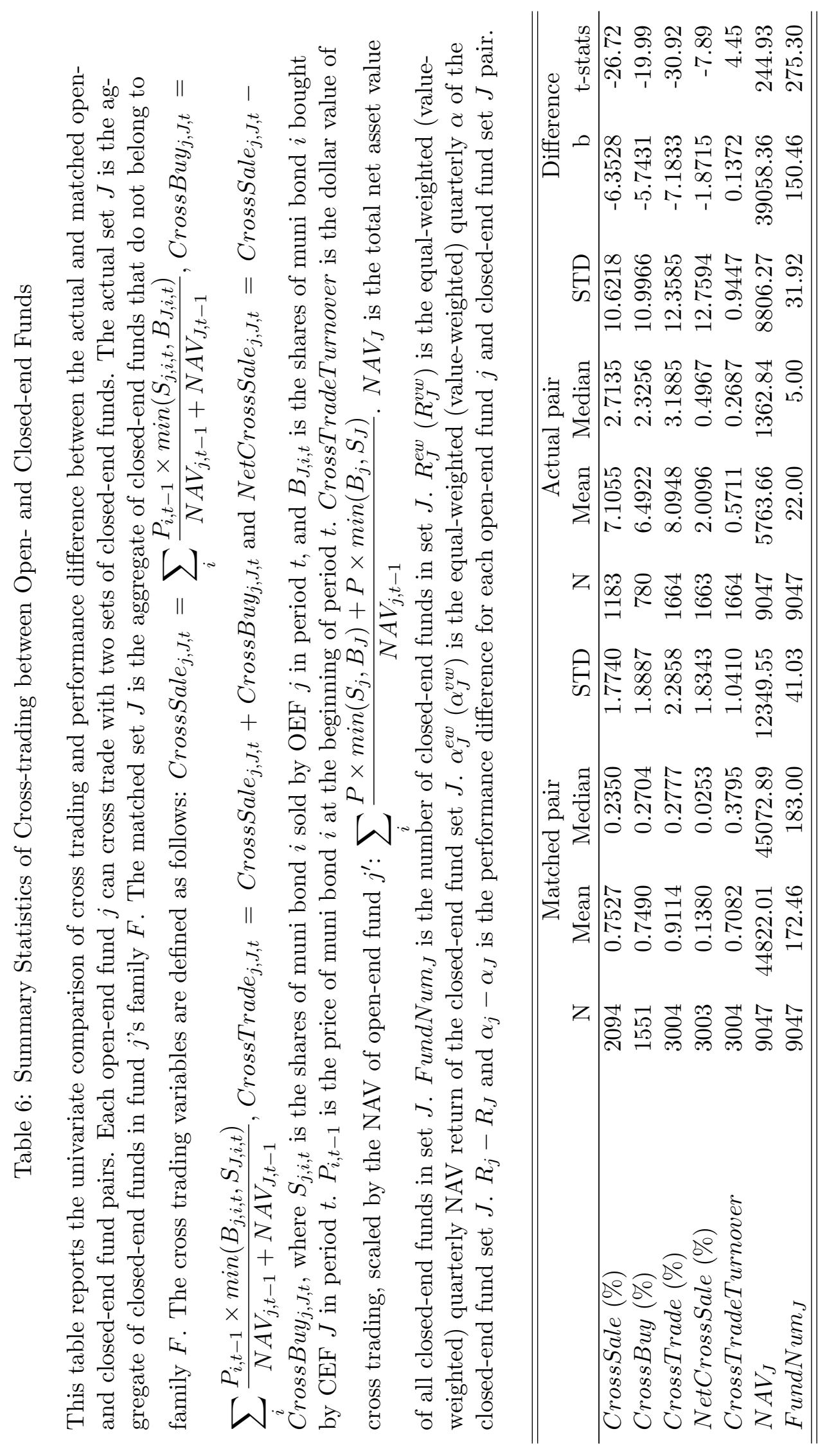


I also run the following piece-wise regression:

$$
\begin{aligned}
& \text { Crosstrade }_{, J}=\alpha+\beta_{1} \text { Affiliated }_{j, J}+\beta_{2} \text { LargeOutflow }_{j}+\beta_{3} \text { Affiliated }_{j, J} \times \\
& \text { LargeOutflow }_{j}+\gamma_{1} \text { Outflow }_{j}+\gamma_{2} \text { Af filiated } \text { f }_{j, J} \times \text { Outflow }_{j}+\theta_{1} \text { Inflow }_{j}+ \\
& \theta_{2}{\text { Af } \text { filiated }_{j, J} \times \text { Inflow }_{j}+\delta_{1} \text { LargeInflow }_{j}+\delta_{2} \text { Af filiated }}_{j, J} \times \text { LargeInflow }_{j}+\text { Controls } .
\end{aligned}
$$

I expect that fund families only use cross-trading as liquidity management channel in extreme situations. Therefore, I expect the coefficient $\beta_{3}$ to be significantly negative while the coefficients $\gamma_{2}$ and $\theta_{2}$ to be insignificant.

Table 7 Column (1) - (4) show the relationship between cross-trading and openend funds' flows. The coefficients on Af filiated dummy, Flow and the interaction are insignificant, suggesting that cross-trading between open- and closed-end funds is not linearly related to open-end fund flows. This finding is not surprising since I expect that cross-trading is only used as a liquidity management channel when open-end funds are in distress. I use piece-wise regression to test whether cross-trading is associated with extreme flows of open-end funds. Table 7 Column (5) - (8) show the piece-wise regression results. Consistent with my hypothesis, the coefficient, $\beta_{3}$, on the interaction between Affiliated and LargeOutflow is significantly negative. Moreover, the coefficients on other flow interactions are mostly insignificant. This result provides evidence that crosstrading between open- and closed-end funds is mostly used as an alternative liquidity management channel when open-end funds are in distress. The coefficient $\left(\beta_{3}=-0.1336\right)$ is larger in magnitude using CrossSale as dependent variable (Column (5)) than that $\left(\beta_{3}=-0.0432\right)$ using CrossBuy as dependent variable (Column (6)). Therefore, the net effect is that open-end funds cross-sell to affiliated closed-end funds when they are in distress. 


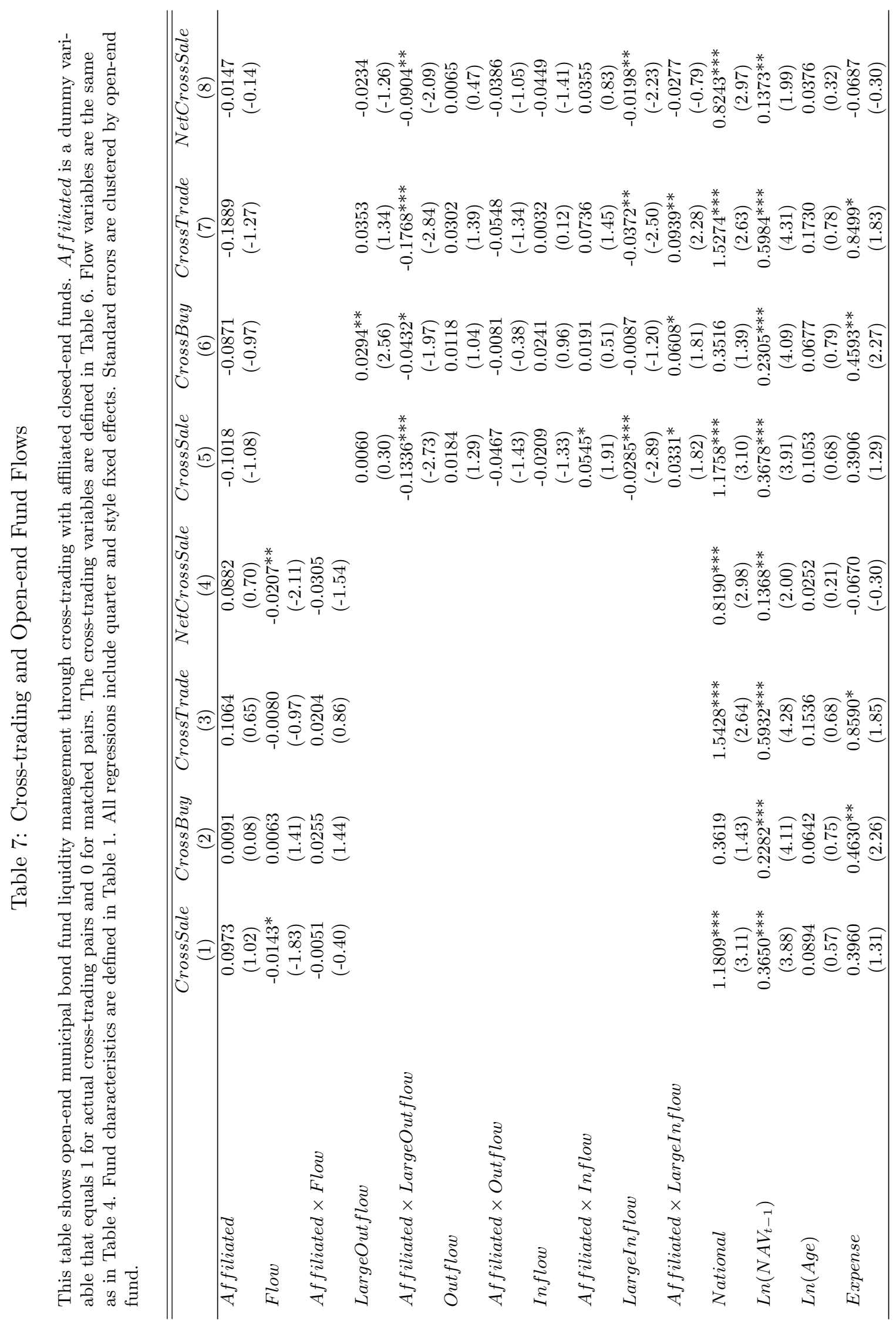




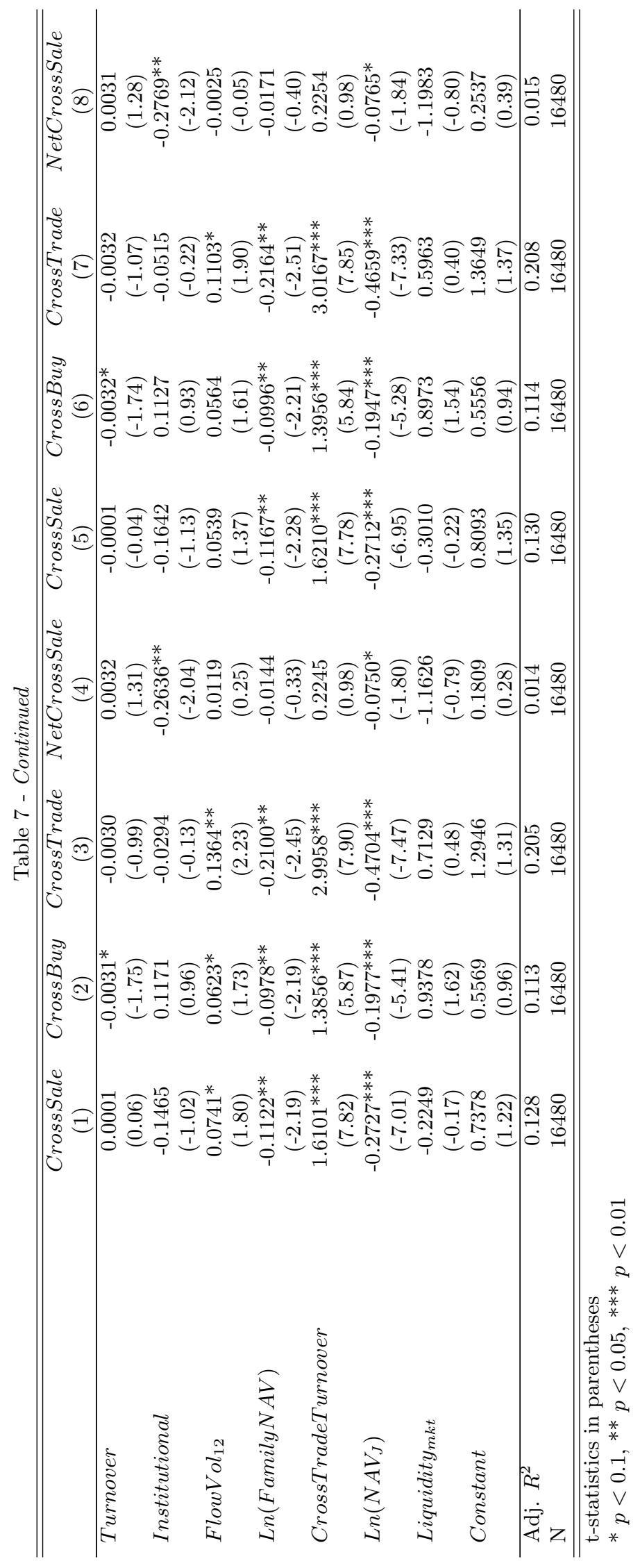


I find a significantly positive association $\left(\delta_{2}=0.0608\right)$ between CrossBuy and LargeInflow for the actual cross-trading pairs. But the association is not statistically significant between NetCrossSale and LargeInflow. This result suggests that although open-end funds with excess cash can cross-buy from affiliated closed-end funds, these cross-buy transactions tend to be limited in size. In untabulated tests, I use top and bottom 10th percentiles as cutoffs to define large inflows and outflows. Compared with the regression results in Table 7 , the coefficient, $\beta_{3}$, is negative but smaller in statistical significance and economic magnitude. The negative association between open-end funds' large outflows and CrossSale and the lack of association between open-end funds' quarterly flows and cross-trading provide evidence that fund families use cross-trading as an alternative liquidity management channel for distressed open-end funds.

Table 7 also shows the relationship between cross-trading and open-end fund characteristics. Open-end funds' investment style and size are strongly related to cross-trading. National dummy is positively correlated with CrossSale, but not correlated with CrossBuy, suggesting that fund families provide more liquidity support to national funds. All crosstrading variables are positively associated with fund size, suggesting that fund families provide more liquidity support to large funds. The coefficients on National and fund size are consistent with each other because national funds, on average, are significantly larger in size than single-state funds. I also find evidence that cross-trading is negatively associated with open-end funds' family size.

In contrast to the cross-subsidization literature, cross-trading between open- and closed-end funds is not associated with open-end fund characteristics, such as expense ratios and age. Since open-end funds with high family value do not receive more crosstrading, I conclude that cross-trading between open- and closed-end municipal bond funds is a channel for liquidity management, rather than cross-subsidization. 


\subsection{Cross-trading and Open-end Fund Performance}

If fund families coordinate cross-trading to support distressed open-end funds, cross-trades should not only correlate with open-end fund flows, but also happen at prices higher than the fire sale prices. Distressed open-end funds avoid costly fire sales through cross-trading in the family internal market. I run the following regression to test how does cross-trading affect open-end fund performance:

$$
\text { Return }_{j}=\alpha+\beta \text { Crosstrade } j+\text { Controls }
$$

Crosstrade $_{j}$ equals to the actual pair cross-trading variables in Table 6 and Table 7 when the fund family manages both open- and closed-end funds, and 0 when the fund family manages only open-end funds. If fund families use cross-trades to avoid fire sales, crosstrading should alleviate the negative abnormal returns at fire sale events. However, an endogeneity problem exists because fund families only use cross-trading when open-end funds face large outflows, which lead to negative abnormal returns at forced liquidation. Because of such endogeneity problem, I do not have a clear expectation on the sign of $\beta$.

Table 8 shows the relationship between return difference and cross-trading. Column (1) - (4) use quarterly net return and Column (5) - (8) use quarterly alpha as openend fund performance measure. CrossBuy is not correlated with fund performance, while CrossSale and NetCrossSale is negatively correlated with fund performance. The negative association is possibly due to endogeneity because open-end funds only engage in cross-trading when they experience large outflows, which can lead to forced liquidations. I address the endogeneity problem in the robustness test. 


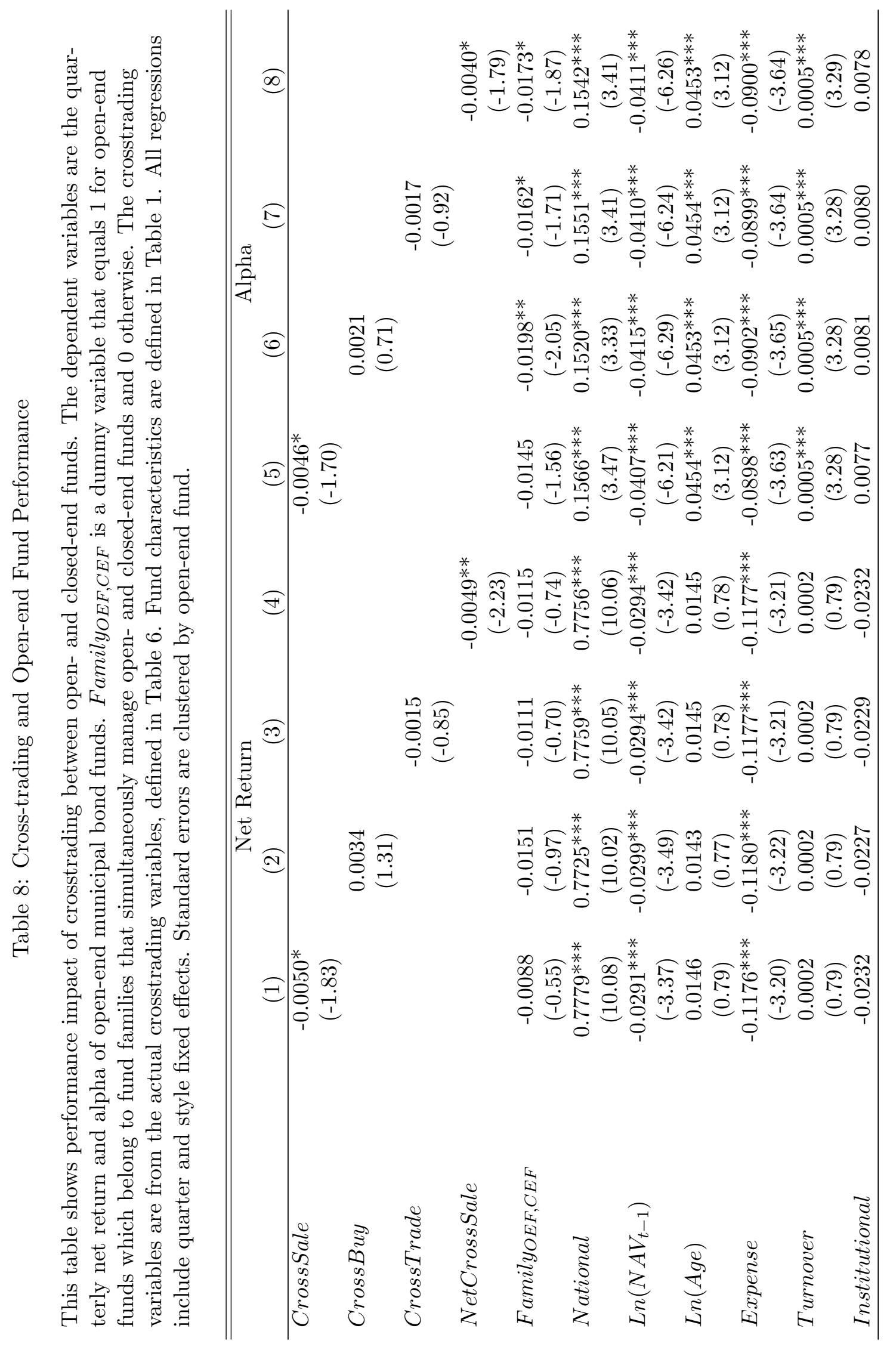




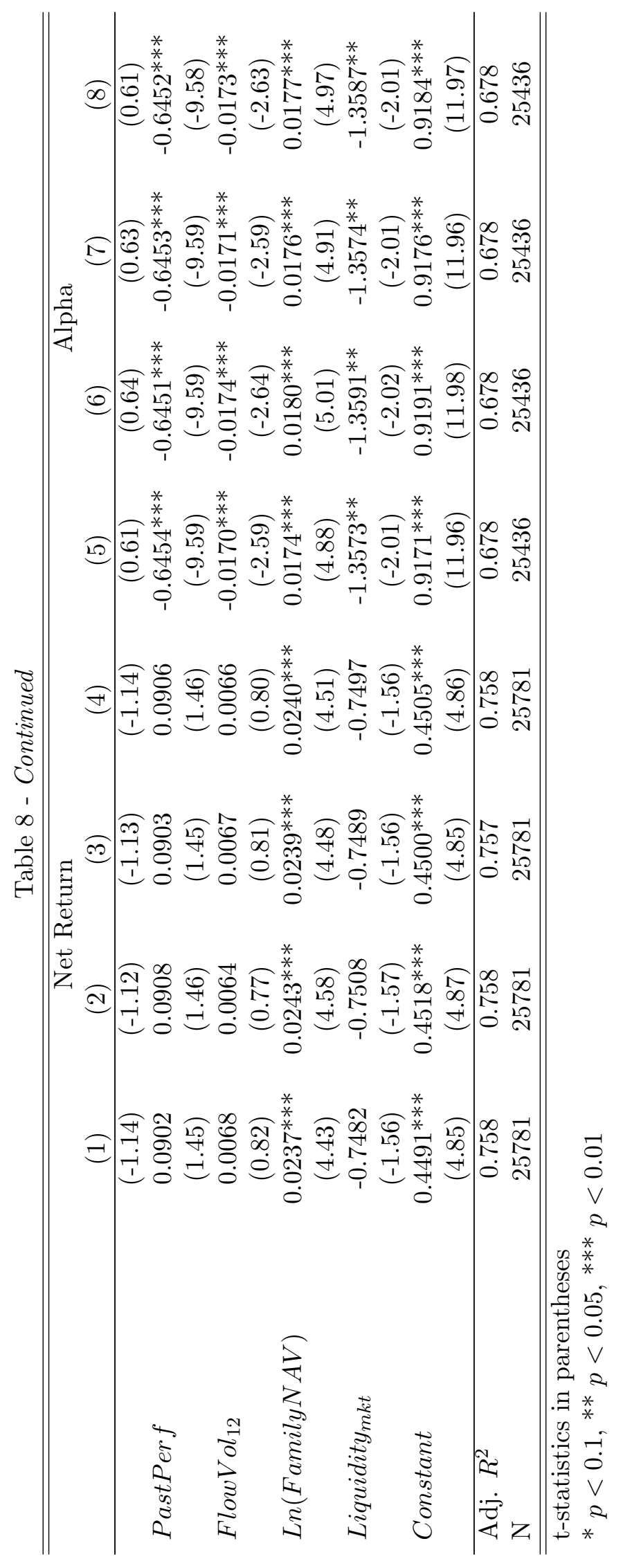


In conclusion, Table 7 provides evidence that fund families use cross-trading as an alternative liquidity management tool. They only coordinate cross-trades between openand affiliated closed-end funds when open-end funds are in distress. The relationship between cross-trading and fund performance remains unclear due to the endogeneity problem: both cross-trading and poor performance are associated with large outflows. I address this concern in Section 6.

\subsection{Cross-trading and Closed-end Fund Characteristics}

In Table 7, I find that open-end fund characteristics, such as fund age and expense ratio, are not associated with cross-trading, suggesting that fund families are not playing favoritism in coordinating cross-trades for open-end funds. In the following session, I test whether closed-end fund characteristics are associated with cross-trading, specifically whether the relationship between cross-trading and closed-end fund characteristics is consistent with family-value maximization.

For each open-end fund $j$ in fund family $F$, I assume that it can cross-trade with every closed-end fund $J_{1}, J_{2}, \ldots, J_{N}$ in family $F$. Therefore, the open-end fund has $N$ potential cross-trading pairs $j-J_{1}, j-J_{2}, \ldots, j-J_{N}$. Suppose a fund family $F$ manages $M$ open-end funds and $N$ closed-end funds, I will have $M \times N$ open- and closed-end fund pairs. For each pair, I construct the cross-trading variables as before. I run the following regressions:

$$
\begin{aligned}
& \text { Cross }- \text { trade }_{j, J_{n}}=\alpha+\beta \text { Flow }_{j}+\text { CEFCharacteristics }+ \text { Controls }
\end{aligned}
$$

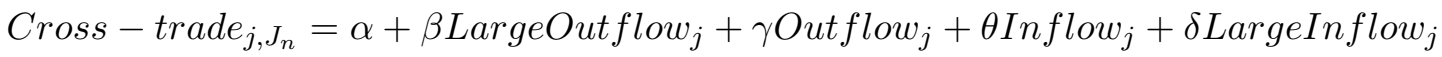

$$
\begin{aligned}
& + \text { CEFCharacteristics }+ \text { Controls } \text {. }
\end{aligned}
$$

Table 9 shows the regression results. Consistent with the results in Table 7, crosstrading is strongly associated with open-end funds extreme flows. CrossSale and NetCrossSale) are negatively associated with LargeOutflow. CrossBuy is positively associated with LargeInflow. 


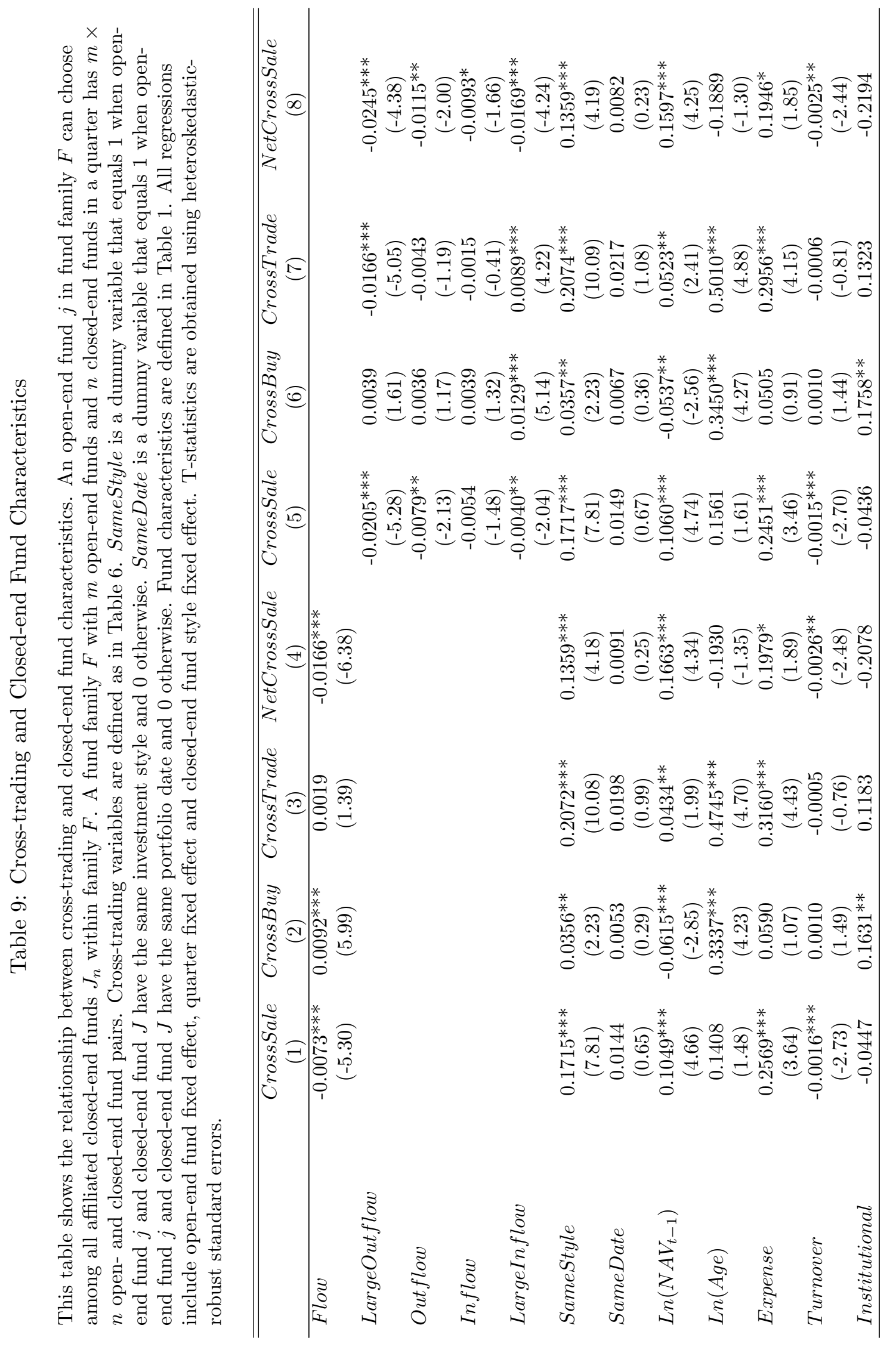




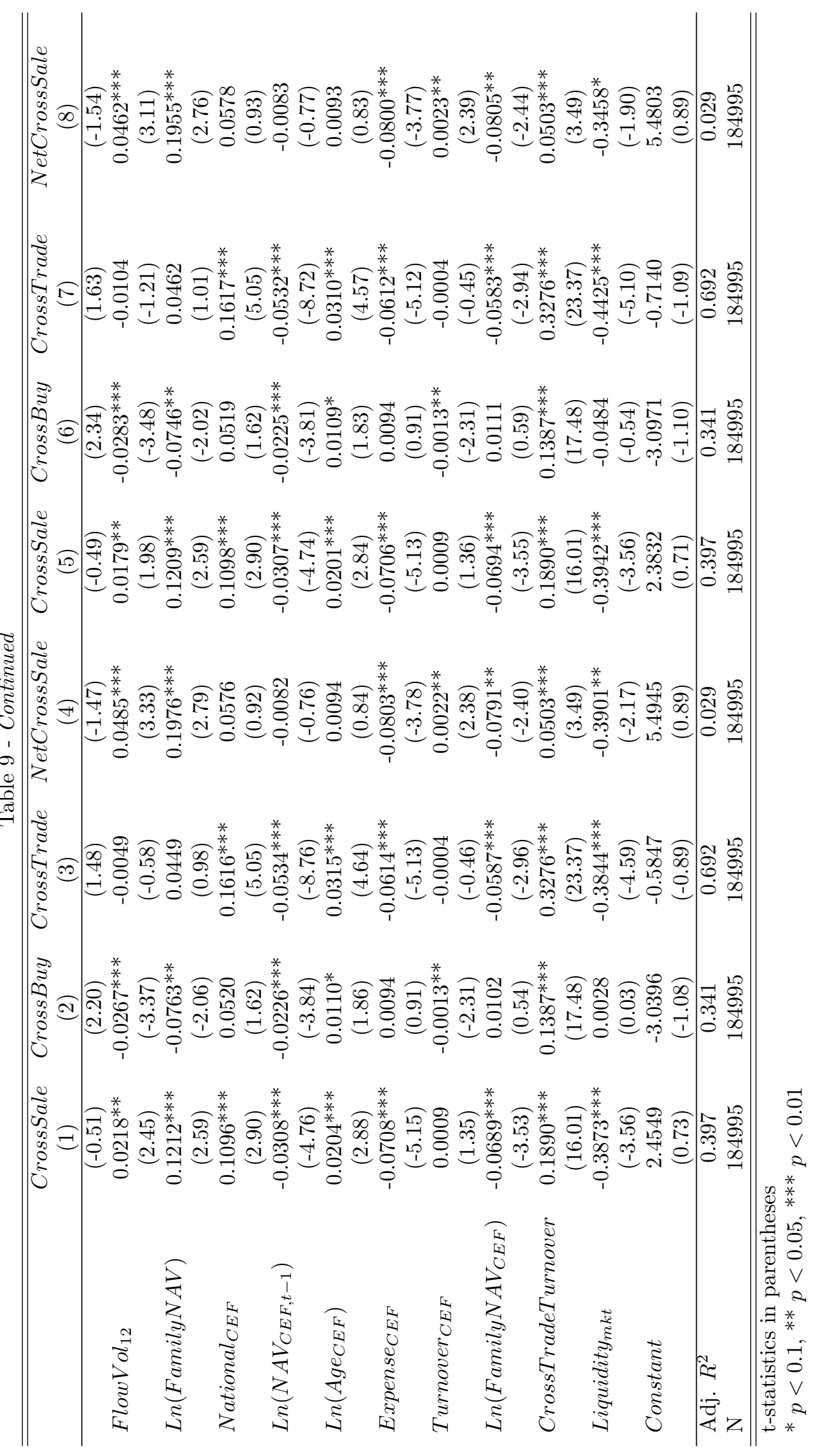


I find a strong style effect in cross-trading. SameStyle is a dummy variable that equals 1 when open- and closed-end fund in the cross-trading pair have the same style. Cross-trading is positively correlated with SameStyle. The association between CrossSale and SameStyle is much stronger than that between CrossBuy and SameStyle, suggesting that open-end funds are more likely to cross-sell to closed-end funds with the same investment style. I also find that closed-end fund style is associated with cross-trading. CrossSale is positively correlated with National $_{C E F}$ dummy, but CrossBuy is not correlated with National $_{C E F}$. This result suggests that open-end funds are more likely to cross-sell to national closed-end funds. The style effect in Table 9 is highly consistent with that in Table 7.

Table 9 shows that cross-trading between open- and closed-end funds is associated with the characteristics of closed-end funds. The expense ratio of closed-end funds, Expense $_{C E F}$, is negatively associated with CrossSale, but not associated with CrossBuy. This negative association provides evidence that consistent with family-value maximization, fund families prefer to use low-fee closed-end funds to provide liquidity to open-end funds. Closed-end funds' age is positively associated with cross-trading. Since mature funds have less growth opportunity, the positive association is consistent with familyvalue maximization. Closed-end funds' family size is negatively associated with CrossSale, but not associated with CrossBuy, suggesting that small fund families use more crosstrading in liquidity management. The negative association between cross-trading and family size is consistent with results in Table 7. In conclusion, the results in Table 9 suggest that fund families prefer to use low-value closed-end funds to cross-trade with openend funds. 


\section{CHAPTER VI}

\section{ROBUSTNESS}

\subsection{Cash Holding and Liquidity Management}

Table 4 shows cash management in open-end municipal bond funds using cash data from Morningstar. Since Morningstar only fund-quarter cash holdings for $49.84 \%$ of the sample, I use cash positions from CRSP as a robustness test of cash management in openend municipal bond funds. Table 10 Panel A shows the relationship between cash holding and flow volatility. Consistent with results in Table 4, the coefficients on FlowVol 12 are significantly positive, suggesting that funds hold more cash when they face high funding liquidity risk. Column (3) of Table 10 Panel A shows cash management in the subsample of national open-end funds. The coefficient on Family ${ }_{O E F, C E F}$ dummy is significantly negative, suggesting that national municipal bond funds hold less cash when their fund families manage closed-end funds at the same time. In contrast to national funds subsam-

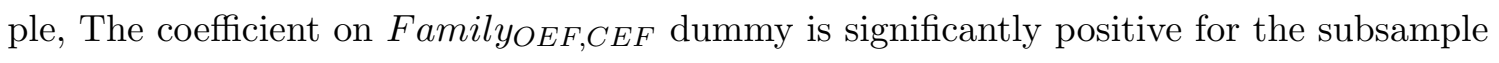
of single-state funds. Cross-trading is one possible explanation for this difference across subsamples. Both Table 7 and Table 9 show that national open-end funds are more likely to engage in cross-trading than single-state funds. Knowing that they have access to alternative liquidity management tools in distress, national open-end funds hold less cash.

Table 10: Robustness Test of Open-end Fund Cash Holdings and Flow Management This table shows open-end municipal bond funds' liquidity management using cash and cash equivalents. Panel A shows the regression of cash holding, Cash $_{\text {crsp }}$, on past flow volatility. Panel B shows the regression of cash holding change, $\Delta$ Cash $_{\text {crsp }}$, on quarterly flow. Fund flow and characteristics are defined in Table 1. Portfolio liquidity variables are defined in Table 2. All regressions include style-quarter fixed effects. Standard errors are clustered by fund.

\begin{tabular}{lcccc}
\hline \hline & Panel A: Level of cash holdings and past flow volatility & \\
& Full sample & Full sample & National & Single-state \\
& $(1)$ & $(2)$ & $(3)$ & $(4)$ \\
\hline Flow Vol $_{12}$ & $0.3241^{* * *}$ & $0.3228^{* * *}$ & $0.3421^{* * *}$ & $0.3131^{* * *}$ \\
\hline
\end{tabular}


Table 10 - Continued

\begin{tabular}{|c|c|c|c|c|}
\hline & (1) & $(2)$ & $(3)$ & (4) \\
\hline & $(4.64)$ & $(4.64)$ & $(3.63)$ & $(3.08)$ \\
\hline \multirow{2}{*}{ FamilyoEF,CEF } & & 0.0851 & $-0.5214^{* *}$ & $0.4122^{* * *}$ \\
\hline & & $(0.63)$ & $(-2.00)$ & $(2.86)$ \\
\hline \multirow[t]{2}{*}{ National } & -0.0319 & -0.0921 & & \\
\hline & $(-0.10)$ & $(-0.29)$ & & \\
\hline \multirow[t]{2}{*}{$\operatorname{Ln}\left(N A V_{t-1}\right)$} & -0.1060 & -0.0998 & -0.1075 & -0.1290 \\
\hline & $(-1.19)$ & $(-1.10)$ & $(-0.67)$ & $(-1.31)$ \\
\hline \multirow[t]{2}{*}{$\operatorname{Ln}(A g e)$} & 0.2220 & 0.2119 & 0.1554 & 0.3519 \\
\hline & $(1.28)$ & $(1.22)$ & $(0.68)$ & $(1.29)$ \\
\hline \multirow[t]{2}{*}{ Expense } & -0.4668 & $-0.5208^{*}$ & -0.2740 & $-0.8701^{* * *}$ \\
\hline & $(-1.63)$ & $(-1.73)$ & $(-0.52)$ & $(-2.66)$ \\
\hline \multirow[t]{2}{*}{ Turnover } & $0.0149^{* * *}$ & $0.0150^{* * *}$ & $0.0162 * * *$ & $0.0102^{* *}$ \\
\hline & $(3.59)$ & $(3.62)$ & $(3.17)$ & $(2.33)$ \\
\hline \multirow[t]{2}{*}{ Institutional } & 0.3125 & 0.2979 & 0.4437 & 0.2137 \\
\hline & $(1.30)$ & $(1.24)$ & (1.11) & $(0.83)$ \\
\hline \multirow[t]{2}{*}{$\operatorname{Ln}($ FamilyN $A V)$} & $-0.1419^{* * *}$ & $-0.1503^{* * *}$ & -0.0602 & $-0.1960^{* * *}$ \\
\hline & $(-2.68)$ & $(-2.65)$ & $(-0.59)$ & $(-3.00)$ \\
\hline \multirow[t]{2}{*}{ Liquidity $_{m k t}$} & 0.2444 & 0.2505 & -1.1545 & 1.1595 \\
\hline & $(0.18)$ & $(0.18)$ & $(-0.45)$ & $(0.72)$ \\
\hline \multirow[t]{2}{*}{ Constant } & $1.2422^{*}$ & $1.3334^{*}$ & 1.0102 & $19.3819^{* * *}$ \\
\hline & $(1.72)$ & $(1.81)$ & $(0.99)$ & $(23.16)$ \\
\hline Adj. $R^{2}$ & 0.077 & 0.077 & 0.080 & 0.073 \\
\hline $\mathrm{N}$ & 22838 & 22838 & 8398 & 14440 \\
\hline
\end{tabular}

Panel B: Change in cash holdings and quarterly flows

\begin{tabular}{lcccc} 
& $(1)$ & $(2)$ & $(3)$ & $(4)$ \\
\hline Flow & $0.0274^{* * *}$ & $0.0266^{* * *}$ & & \\
LargeOutflow & $(7.01)$ & $(6.89)$ & & 0.0127 \\
& & & 0.0118 & $(1.41)$ \\
Outflow & & $(1.31)$ & $0.0272^{* *}$ \\
& & & $0.0257^{* *}$ & $(2.38)$ \\
Inflow & & $(2.24)$ & $0.0457^{* * *}$ \\
& & & $0.0443^{* * *}$ & $(3.84)$ \\
LargeInflow & & $(3.71)$ & $0.0257^{* * *}$ \\
& & & $0.0280^{* * *}$ & $(4.67)$ \\
National & & & $(4.91)$ & 0.0874 \\
& & & 0.1084 & $(0.41)$ \\
Ln $($ NAV $t-1)$ & $(0.41)$ & $(0.31)$ & $(0.50)$ & 0.0034 \\
& -0.0034 & 0.0015 & -0.0012 & $(0.29)$ \\
Ln $($ Age $)$ & $(-0.29)$ & $(0.13)$ & $(-0.10)$ & $0.0639^{* *}$ \\
Expense & $0.0646^{* *}$ & $0.0541^{* *}$ & $0.0754^{* * *}$ & $(2.53)$ \\
& $(2.47)$ & $(2.15)$ & $(2.89)$ & $(2.16)$ \\
Turnover & $0.0712^{* *}$ & $0.0716^{* *}$ & $0.0743^{* *}$ & $0.0782^{* *}$ \\
\hline
\end{tabular}


Table 10 - Continued

\begin{tabular}{|c|c|c|c|c|}
\hline & $(1)$ & $(2)$ & $(3)$ & $(4)$ \\
\hline & $(1.55)$ & $(2.09)$ & $(1.51)$ & $(2.06)$ \\
\hline \multirow[t]{2}{*}{ Institutional } & 0.0324 & 0.0317 & 0.0271 & 0.0274 \\
\hline & $(1.05)$ & (1.08) & $(0.86)$ & $(0.90)$ \\
\hline \multirow[t]{2}{*}{$\operatorname{Ln}($ FamilyNAV) } & 0.0107 & 0.0104 & 0.0088 & 0.0085 \\
\hline & $(1.60)$ & $(1.56)$ & $(1.28)$ & $(1.23)$ \\
\hline \multirow[t]{2}{*}{ Liquidity $_{m k t}$} & 0.1211 & 0.1759 & 0.1253 & 0.1800 \\
\hline & $(0.11)$ & $(0.16)$ & $(0.11)$ & $(0.17)$ \\
\hline \multirow{2}{*}{ AvgVolume $_{3, t-1}$} & $-0.0213^{* * *}$ & & $-0.0216^{* * *}$ & \\
\hline & $(-4.88)$ & & $(-4.93)$ & \\
\hline \multirow[t]{2}{*}{ AvgVolume $_{12, t-1}$} & & $-0.0062^{* * *}$ & & $-0.0063^{* * *}$ \\
\hline & & $(-5.59)$ & & $(-5.65)$ \\
\hline \multirow[t]{2}{*}{ Constant } & -0.3373 & -0.3249 & $-0.3904^{*}$ & $-0.3725^{*}$ \\
\hline & $(-1.58)$ & $(-1.51)$ & $(-1.81)$ & $(-1.71)$ \\
\hline Adj. $R^{2}$ & 0.017 & 0.016 & 0.017 & 0.017 \\
\hline $\mathrm{N}$ & 21168 & 21165 & 21168 & 21165 \\
\hline
\end{tabular}

t-statistics in parentheses

${ }^{*} p<0.1,{ }^{* *} p<0.05,{ }^{* * *} p<0.01$

Table 10 Panel B shows the relationship between cash position change and flow management. Cash holding change is positively associated with quarterly flows, suggesting that open-end municipal bond funds use cash to accommodate flows. Column (3) and (4) show piece-wise regression results. The coefficients on LargeOutflow is insignificant, while the coefficients on Outflow, Inflow and LargeInflow are significantly positive. Consistent with results in Table 4, the piece-wise regressions show that open-end municipal bond funds use alternative liquidity management tools, instead of cash, in extreme situations.

\subsection{Cross-trading between Open- and Closed-end Funds}

\subsubsection{Cross-trading and Characteristic-matched Sample}

Table 6 shows that the net asset value of and the number of funds in closed-end fund set $J$ are significantly larger for matched pairs than actual pairs. To address the concern that 
regression results in Table 7 is driven by the difference in closed-end fund size between actual and matched pair, I run the robustness test using a characteristic-matching method.

I use the matched-sample methodology in Section 5.1 to construct the actual crosstrading pairs. For each open-end fund $j$ in family $F$, I assume that it cross-trades with the set $J$ of affiliated closed-end funds that belong to the same family $F$. For each quarter and each style, closed-end funds are sorted into four quartiles according to their fund size, age or expense ratio. Each closed-end fund in the actual set $J$ is randomly matched to an unaffiliated closed-end fund that belongs to the same style and characteristic quartile. The matched set $J$ is the aggregate of these style- and characteristics-matched unaffiliated closed-end funds.

Table 11 shows the summary statistics of cross-trades for actual and matched pairs. Panel A, B and C separately show the univariate comparisons between actual cross-trading pairs and size-, age- and expense-matched pairs. The average size of closed-end fund set $J$ in the actual pairs is similar to that in the matched pairs. The cross-trading variables in actual pairs are significantly larger than those in matched pairs.

Table 12 shows the relationship between cross-trading and open-end fund flows. I use CrossSale and NetCrossSale as dependent variables. The regression results are highly consistent with that in Table 7 . The coefficients on Af filiated is significantly positive. The piece-wise regression results show that cross-trading is significantly associated with open-end funds' large outflows. The coefficients on the interaction between Af filiated and LargeOutflow are significantly negative, suggesting that distressed openend funds cross-sell to closed-end funds in the family internal market. The coefficients on other flow variables are insignificant. In the untabulated robustness test, I also find that CrossBuy is not associated with open-end fund's inflows. Consistent with Table 7, Table 12 shows that large national open-end funds are more likely to engage in cross-trading and that cross-trading is not associated with open-end fund characteristics. The results in 12 provide additional evidence that fund families use cross-trading as an alternative liquidity management tool when open-end funds are in distress. 


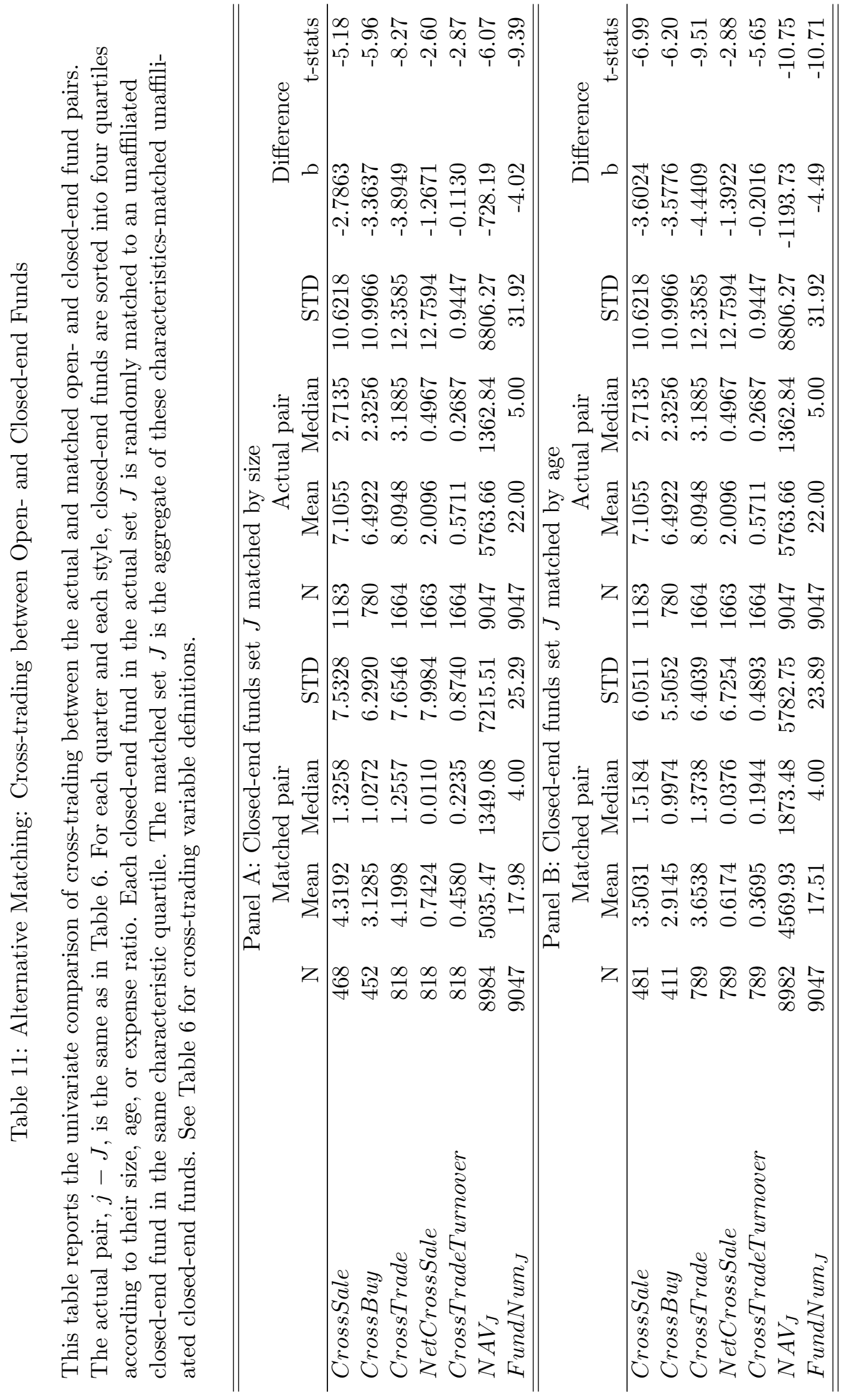




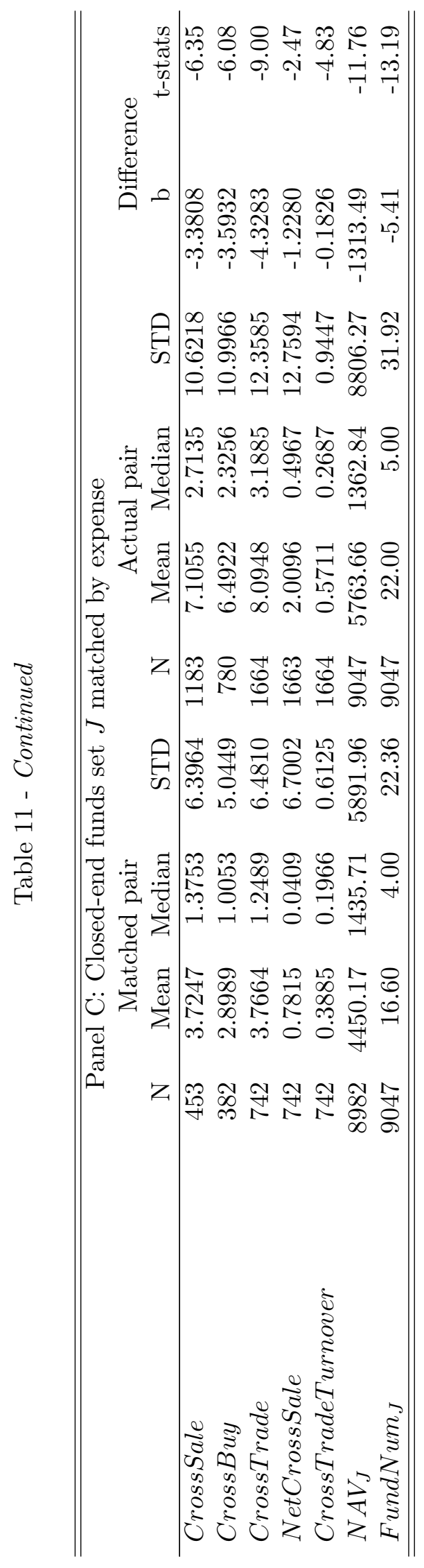




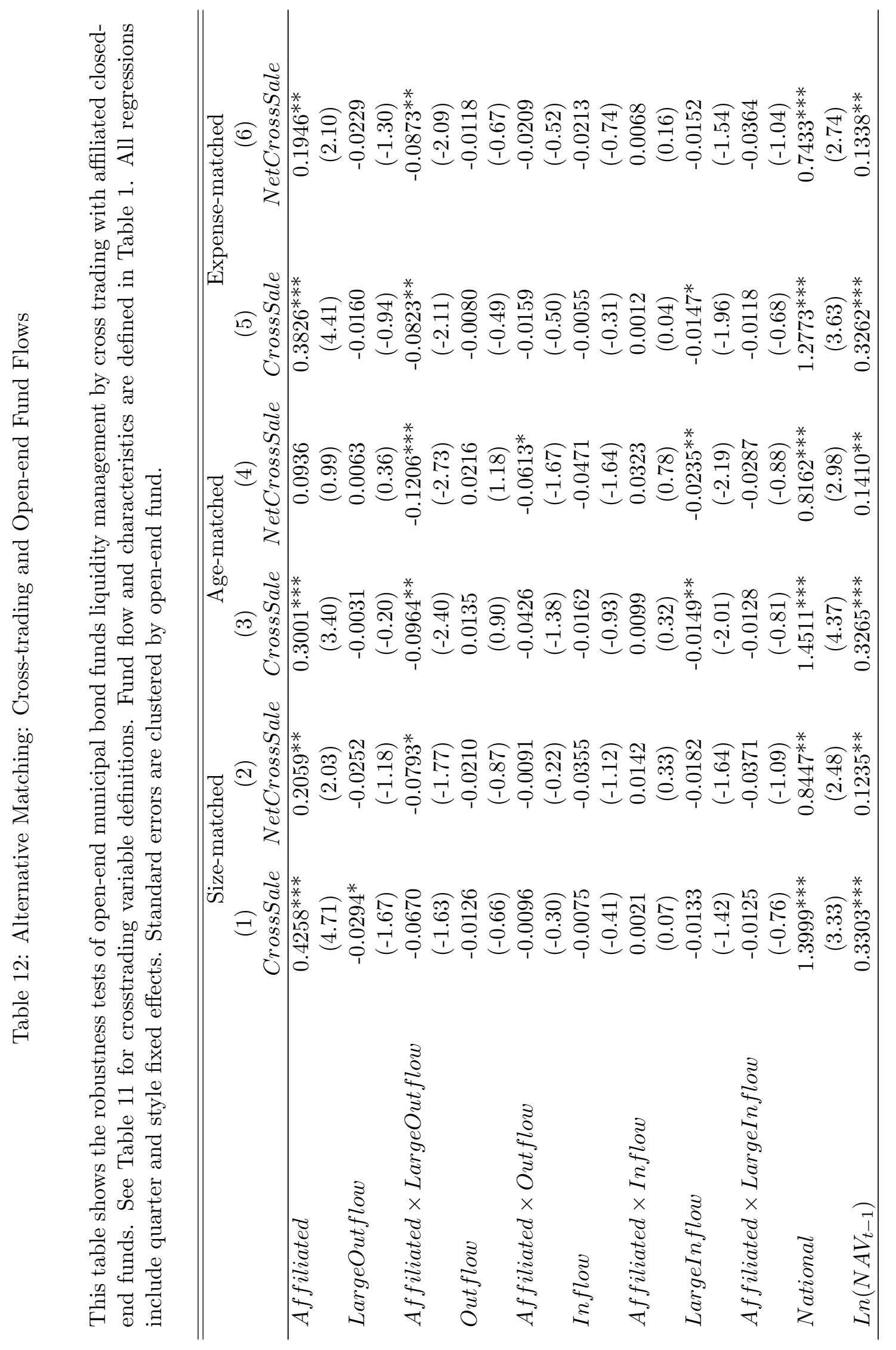




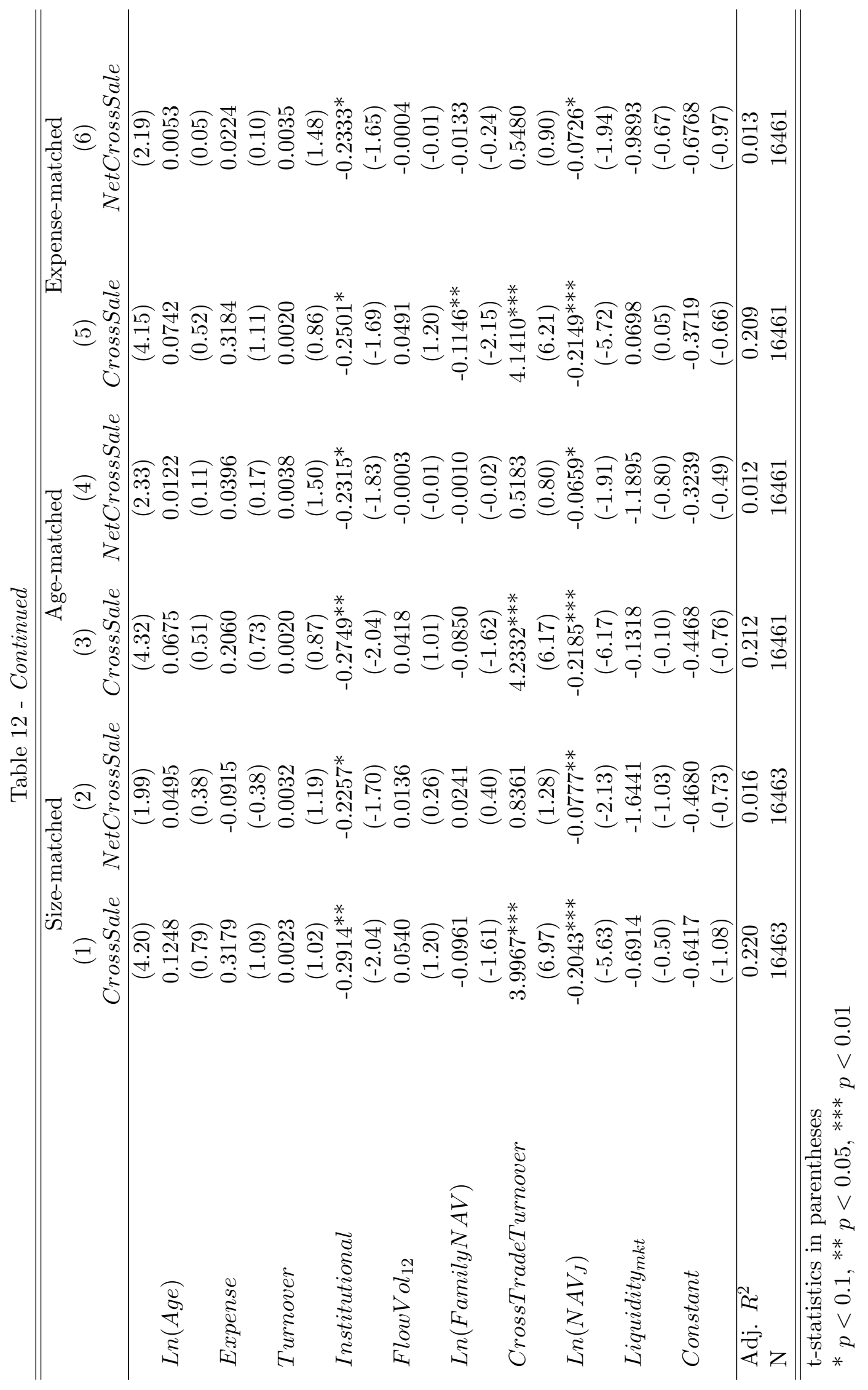




\subsubsection{Cross-trading Policy of Investment Advisors}

I also run robustness tests using cross-trading policies of open-end fund investment advisors. An investment advisory firm with a strict policy that allows little cross-trading opportunities cannot use cross-trading to provide liquidity to distressed open-end funds. Therefore, I expect that liquidity-motivated cross-trading only exists in fund families that allow cross-trading.

The SEC requires investment advisors to disclose their cross-trading policies ${ }^{17}$ in Item $8 \mathrm{~B}$ of Form $\mathrm{ADV}$. Investment advisors answer yes or no to three questions about whether they allow cross-trading between two clients or not ${ }^{18}$. I use the Agency Crosstrading (ACT) measure following Casavecchia and Tiwari (2016) and Del Guercio, Genc and Tran $(2017)^{19}$. ACT with a value of 0 means that the investment advisor is not allowed to coordinate cross-trading between two clients, and a value of 3 means that the investment advisor have the most opportunities to engage in agency cross-trading. HighACT is a dummy variable that equals to 1 when $A C T \geq 2$ and 0 when $A C T<2$. Most fund families, such as Nuveen, Pimco and Dreyfus, hold the same cross-trading policies across their investment subsidiaries and throughout the sample period. I only find 4 fund families that changed their cross-trading policies over time, including BlackRock, Delaware Investments, Invesco and Legg Mason.

I divide open-end funds into two subsamples according to their investment advisors' cross-trading policies and test whether the cross-trading activities are different in the two subsamples. Table 13 shows the univariate comparison of cross-trading between the high $A C T$ and low $A C T$ subsamples. I compare the actual cross-trading across the two sub-

\footnotetext{
${ }^{17}$ See Table 3 of Casavecchia and Tiwari (2016) or SEC Form ADV for the list of questions regarding agency cross-trading.

${ }^{18}$ Investment advisors' answers to Form ADV are downloaded from the SEC website. I use hand-collect information on investment advisors' SEC file number to merge the Form ADV data with Morningstar dataset. I match 7932 fund-quarter observations from 19 fund families.

${ }^{19}$ Form ADV data are only available since 2009. I follow Del Guercio, Genc and Tran (2017) and use 2009 data to backfill observations before 2009 .
} 
samples and find that the average CrossSale and CrossBuy are significantly larger in the high $A C T$ subsample than those in the low $A C T$ subsample. I do not find significant difference across two subsamples for the matched cross-trading variables. Table 13 Panel C shows the univariate comparison of open-end funds characteristics. Fund families that allow more opportunities in cross-trading are smaller in family size and open-end funds in these families have higher flow volatility.

Table 14 shows the piece-wise regression results for two subsamples. In the high $A C T$ subsample, cross-trading is significantly correlated with open-end fund flows. The coefficient on the interaction between Af filiated and LargeOutflow is significantly negative when I use CrossSale as dependent variable and insignificant when I use CrossBuy as dependent variable. I find modest evidence that open-end fund with large inflows crossbuy from affiliated closed-end funds: CrossBuy is positively associated with LargeInflow but the significance goes away when I look at the net cross-trading. The piece-wise regression results in the high $A C T$ subsample provide evidence that distressed open-end funds cross-sell to affiliated closed-end funds when the fund's investment advisor are allowed to coordinate cross-trading. In the low $A C T$ subsample, I find no evidence that cross-trading is correlated with open-end fund flows. The coefficients on flow variables are mostly insignificant, suggesting that open-end funds do not use cross-trading as a liquidity management tool when the investment advisors are not allowed to engage in crosstrading. In conclusion, the subsample tests in Table 14 are consistent with my hypothesis that fund families use cross-trading as an alternative liquidity management channel when open-end funds are in distress. 


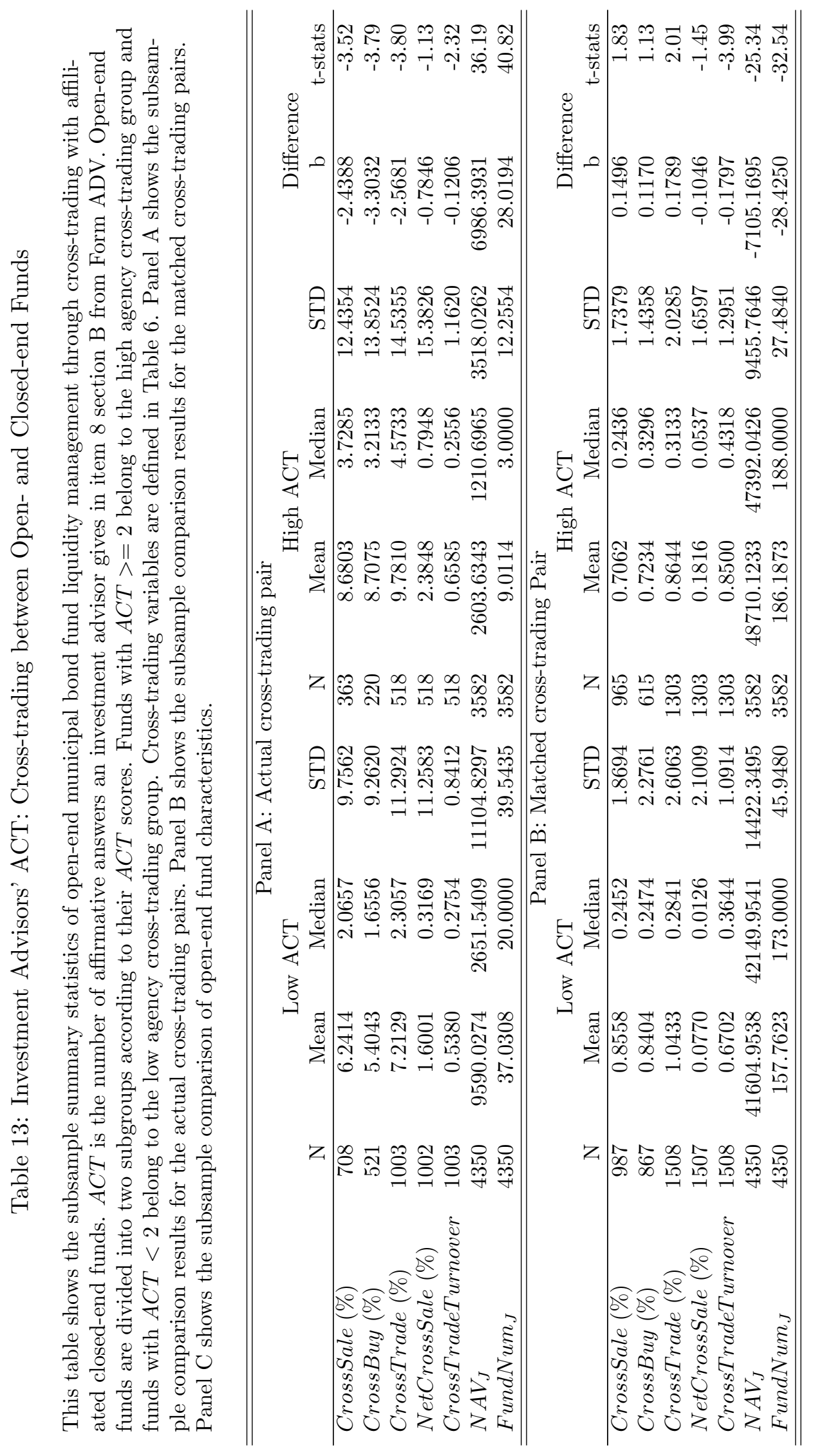




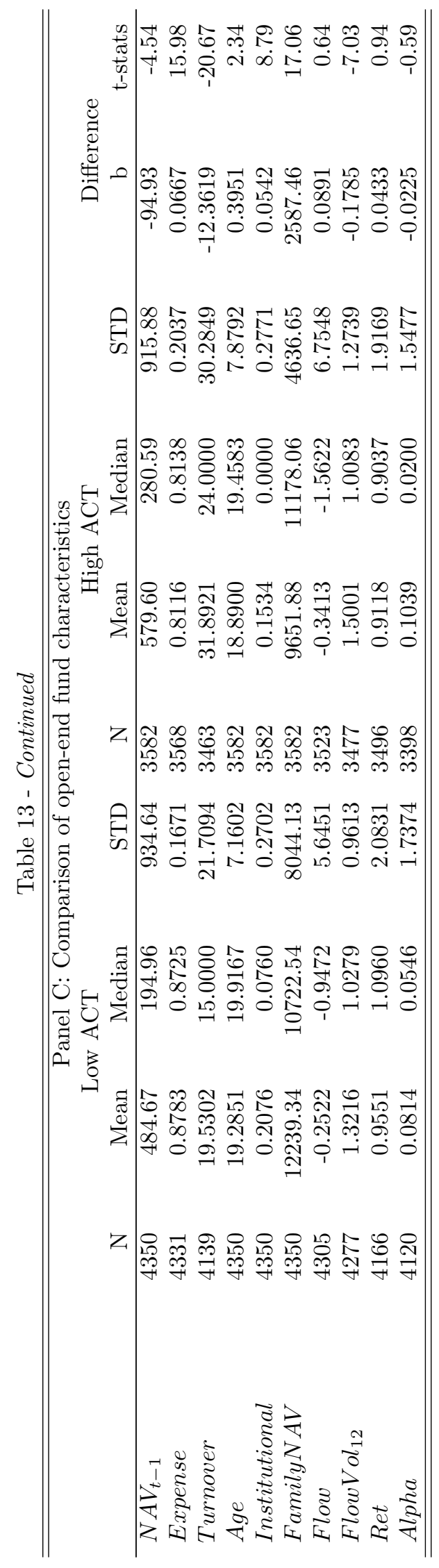




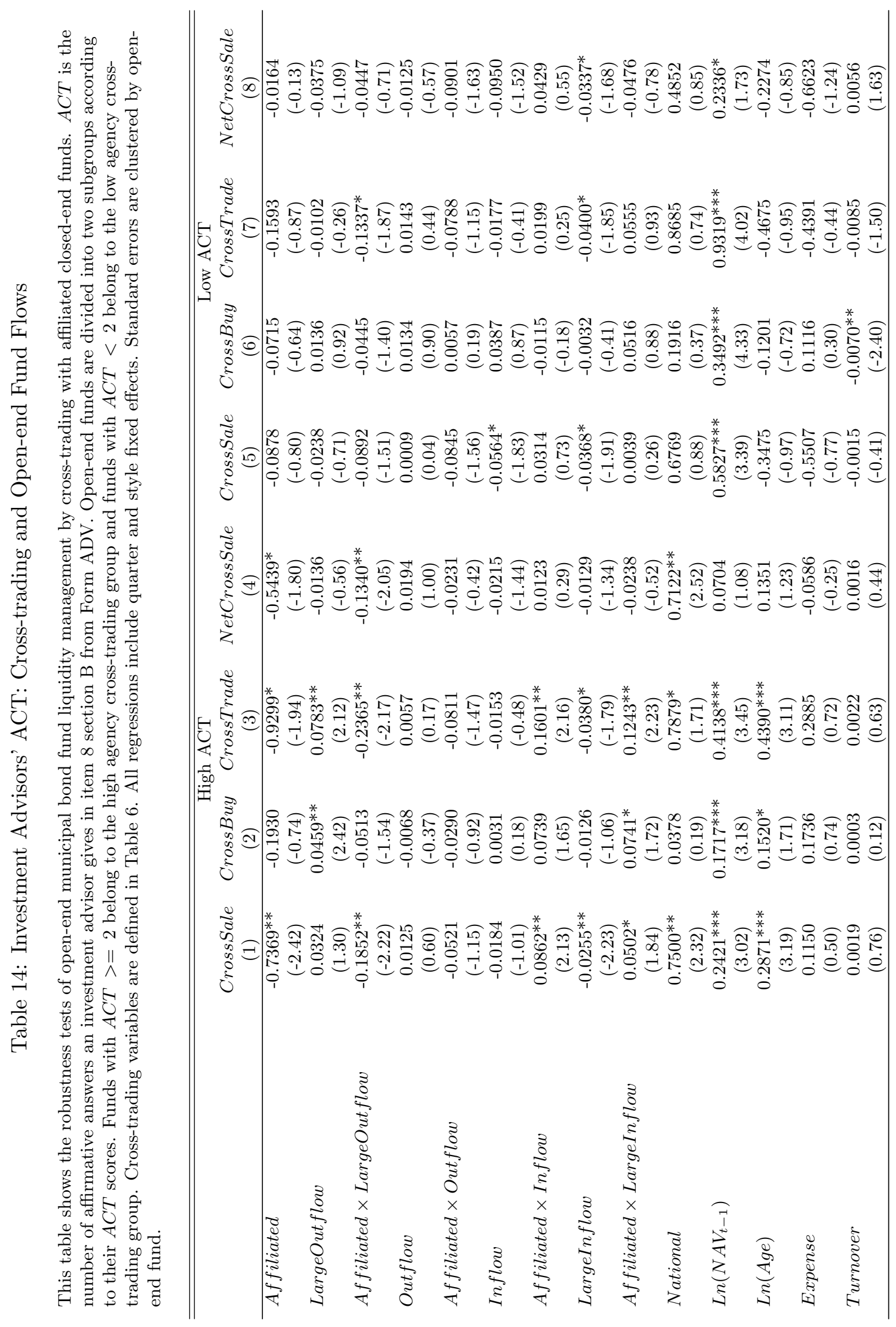




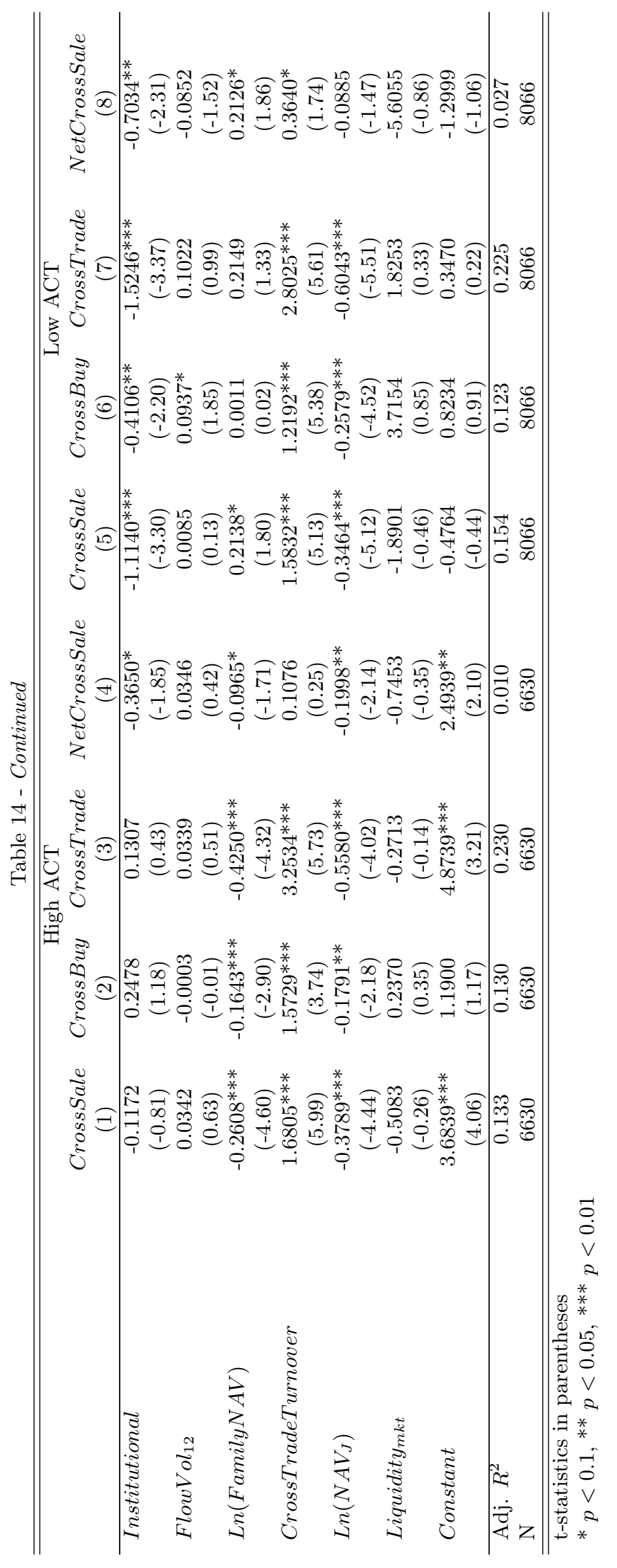




\subsubsection{SLS - Cross-trading and Open-end Fund Performance}

In Section 5, I use OLS regressions to test how cross-trading affects open-end fund performance. Table 8 shows that CrossSale and NetCrossSale are negatively associated with open-end fund performance. Such a negative association is possibly caused by the endogeneity issue: both cross-trading and fund performance are driven by contemporaneous fund flows. I use $A C T$ as instrumental variable and run 2SLS regressions to overcome the endogeneity problem. The cross-trading policy of an investment advisor is determined at the fund's inception and tends to be highly stable over time. Most investment advisors do not change the cross-trading rules throughout the fund's life. Those who make changes usually stick with the new cross-trading policies for at least a few years.

Table 15 shows the second-stage regression results. After using the IV regression, I

find no correlation between cross-trading and open-end fund performance, suggesting that cross-trading do not affect fund performance. There are two possible explanations. First, fund families strictly follow the SEC's "fair price" rule on cross-trading, therefore, crosstrading do not affect open-end fund performance. Second, fund families give preferential treatment to open-end funds in internal market cross-trading. However, the economic magnitude of preferential treatment in cross-trading is not enough to offset the negative impact of forced liquidation. The fund performance test in Table Table 15 is unable to tell whether open-end funds get favorable prices when they cross-trade with affiliated closed-end funds. If they do, I expect that the preferential treatment is most significant in funds with weak governance. Further tests that control for open-end funds' governance may deepen our understanding on how fund families use cross-trading in liquidity management. 


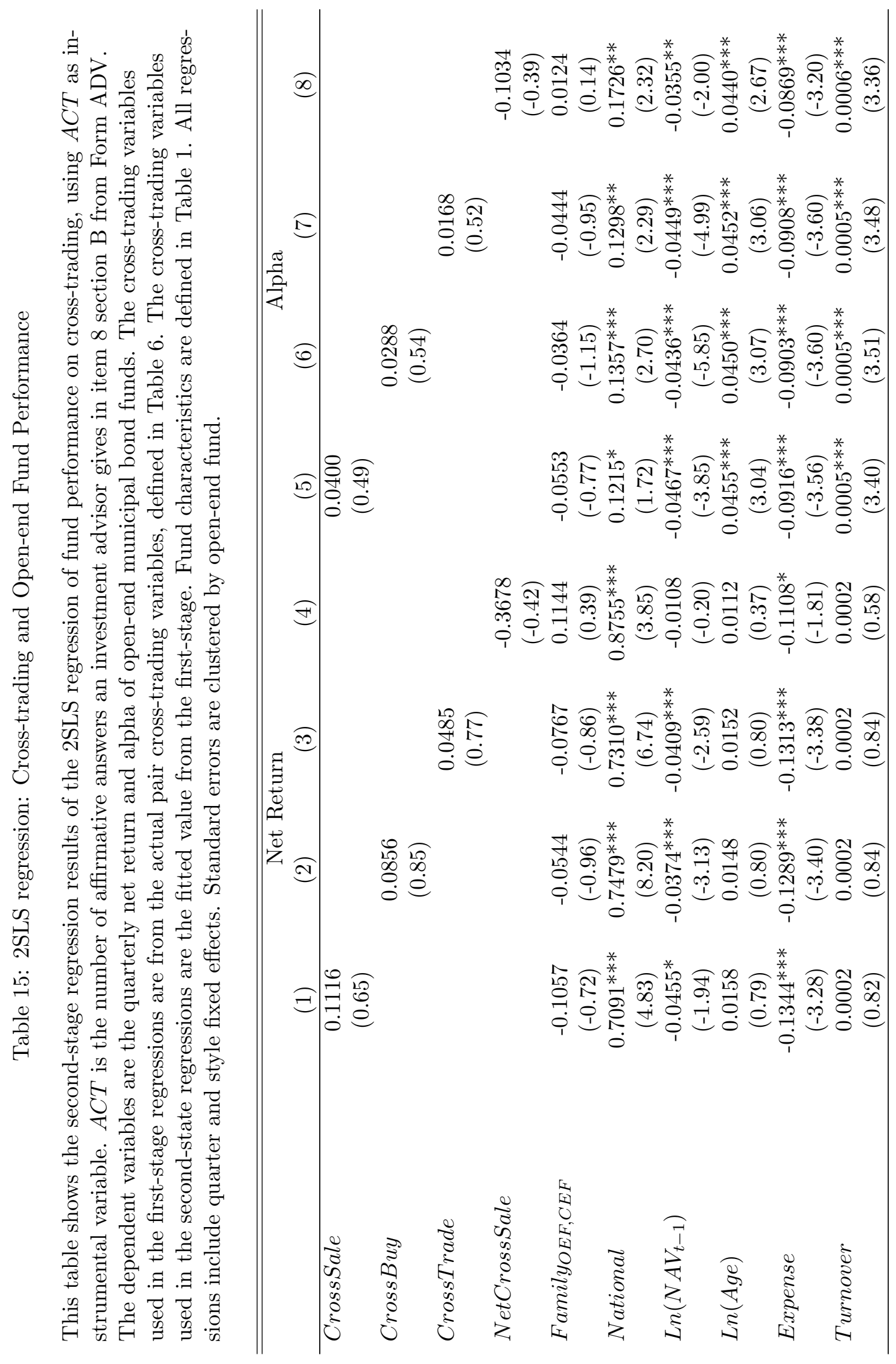




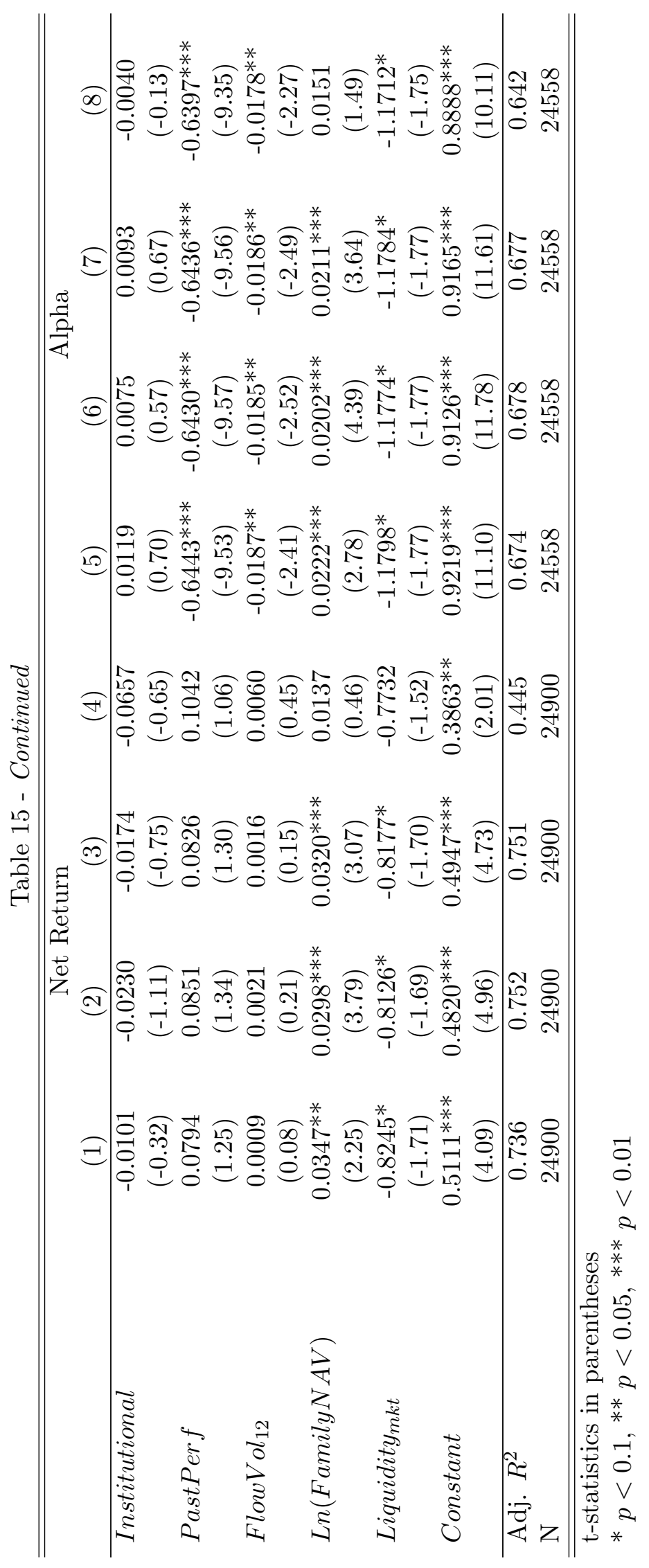




\section{CHAPTER VII CONCLUSION}

In this paper, I start with examining the flow-performance relationship in municipal bond funds. I find that investor flows are highly sensitive to past good and poor performance. The high flow-performance sensitivity and low liquidity in the municipal bond market give fund managers incentive to manage liquidity risk. I study the cash position and portfolio liquidity of municipal bond funds and find evidence of active liquidity management. Municipal bond funds build liquidity buffers when they have high liquidity risk. They use cash and liquid securities to accommodate investor flows. Open-end municipal bond funds, on average, hold limited cash in their portfolios because of the low flow-volatility. However, the low cash holdings also means that cash buffers are not enough to meet large investor redemptions. Therefore, municipal bond funds turn to alternative liquidity management tools in extreme situations. I find evidence of family-level liquidity management through cross-trading. Fund families coordinate cross-trading between open- and closedend funds when open-end funds experience large outflows. The coordinated cross-trading tends to be one-way: distressed open-end funds cross-sell to affiliated closed-end funds. 


\section{APPENDIX A}

\section{MUNICIPAL BOND PRICE}

I search MSRB and Morningstar database for information on month-end prices of munici-

pal bonds. MSRB municipal bond trading database reports the trading price and time for each transaction. Morningstar mutual fund holding database gives the quarter-end price of each municipal bond held by an investment funds. I follow these steps to determine a municipal bond's month-end price:

(1) I search MSRB database for municipal bonds that are traded at least once on the last day of a month. I use the last dealer-purchase transaction price as the bond's month-end bid price and the last dealer-sell price as the bond's month-end ask price. If a bond has both month-end bid and ask price estimates, I compute its month-end price by averaging the two estimates. If only bid or ask price is available, I use it as the monthend price.

(2) I search MSRB database for municipal bonds that are traded at any time within a month. I use the prices of the last dealer-purchase and dealer-sell transactions and adjust them by maturity-matched Barclay municipal index returns to estimate the monthend bid and ask prices. The month-end price is the simple average. If only one price is available, I use it as the month-end price.

(3) I search Morningstar holding dataset for municipal bonds that are held by at least one municipal bond fund at the end of a month. The bond's month-end price is the median of all prices reported by municipal bond funds that hold the bond at the end of the month.

I follow Cici and Gibson (2012) and require each municipal bond to have at least one year to maturity to be included in the sample. 


\section{APPENDIX B}

\section{CASH HOLDINGS IN THE PREVIOUS LITERATURE}

Table B1: Cash Holdings from Mutual Fund Liquidity White Paper

This table shows the sample mean statistics from Hanouna, Novak, Riley and Stahel (2015) Liquidity and Flows of U.S. Mutual Funds. The cash holding data is from Table 5 Panel A in their paper. The flow volatility (1999-2014) data is from Table 6 Panel A. Percentiles of monthly flow (1999-2014) are from Table 8 Panel A.

\begin{tabular}{lrrrrrr}
\hline \hline & \multicolumn{2}{c}{ Cash (End of 2014) } & \multicolumn{2}{c}{ Flow Volatility } & \multicolumn{2}{c}{ Monthly Flow } \\
& Mean & SD & Mean & SD & P5 & P95 \\
\hline All & $4.1 \%$ & $12.8 \%$ & $5.9 \%$ & $5.7 \%$ & $-4.8 \%$ & $8.4 \%$ \\
Alternative Strategy & $22.9 \%$ & $32.2 \%$ & $13.6 \%$ & $10.2 \%$ & $-18.7 \%$ & $28.6 \%$ \\
Foreign Bonds & $5.1 \%$ & $19.0 \%$ & $8.2 \%$ & $5.9 \%$ & $-6.5 \%$ & $11.3 \%$ \\
Foreign Equity & $2.6 \%$ & $6.5 \%$ & $6.3 \%$ & $5.2 \%$ & $-5.2 \%$ & $9.5 \%$ \\
General Bonds & $2.9 \%$ & $13.4 \%$ & $6.6 \%$ & $6.2 \%$ & $-5.9 \%$ & $9.2 \%$ \\
Mixed Strategy & $5.9 \%$ & $15.0 \%$ & $5.3 \%$ & $5.1 \%$ & $-3.9 \%$ & $8.4 \%$ \\
Mortgage-Backed Securi- & $-1.6 \%$ & $15.1 \%$ & $6.3 \%$ & $4.7 \%$ & $-5.3 \%$ & $10.8 \%$ \\
ties & & & & & & \\
US Corporate Bonds & $2.5 \%$ & $12.0 \%$ & $4.9 \%$ & $4.1 \%$ & $-4.5 \%$ & $6.2 \%$ \\
US Equity & $3.1 \%$ & $7.7 \%$ & $5.8 \%$ & $5.5 \%$ & $-4.8 \%$ & $8.4 \%$ \\
US Government Bonds & $2.8 \%$ & $14.0 \%$ & $6.5 \%$ & $5.9 \%$ & $-5.8 \%$ & $8.5 \%$ \\
US Municipal Bonds & $1.9 \%$ & $4.2 \%$ & $2.7 \%$ & $2.6 \%$ & $-3.1 \%$ & $3.6 \%$ \\
\hline \hline
\end{tabular}

US open-end municipal bond funds from 2002 to June 2016

\begin{tabular}{|c|c|c|c|c|c|c|}
\hline & \multicolumn{2}{|c|}{ Cash } & \multicolumn{2}{|c|}{ FlowVol 12} & \multicolumn{2}{|c|}{ Monthly Flow } \\
\hline & Mean & SD & Mean & SD & P5 & P95 \\
\hline \multirow[t]{3}{*}{ US Municipal Bonds } & $1.52 \%$ & $2.26 \%$ & $1.47 \%$ & $1.10 \%$ & $-3.09 \%$ & $3.57 \%$ \\
\hline & \multicolumn{2}{|c|}{ Cash $_{C R S P}$} & \multicolumn{2}{|c|}{ FlowVol $_{24}$} & \multicolumn{2}{|c|}{ Quarterly Flow } \\
\hline & Mean & SD & Mean & SD & $\mathrm{P} 5$ & P95 \\
\hline US Municipal Bonds & $2.22 \%$ & $3.51 \%$ & $1.63 \%$ & $1.07 \%$ & $-7.77 \%$ & $10.75 \%$ \\
\hline
\end{tabular}




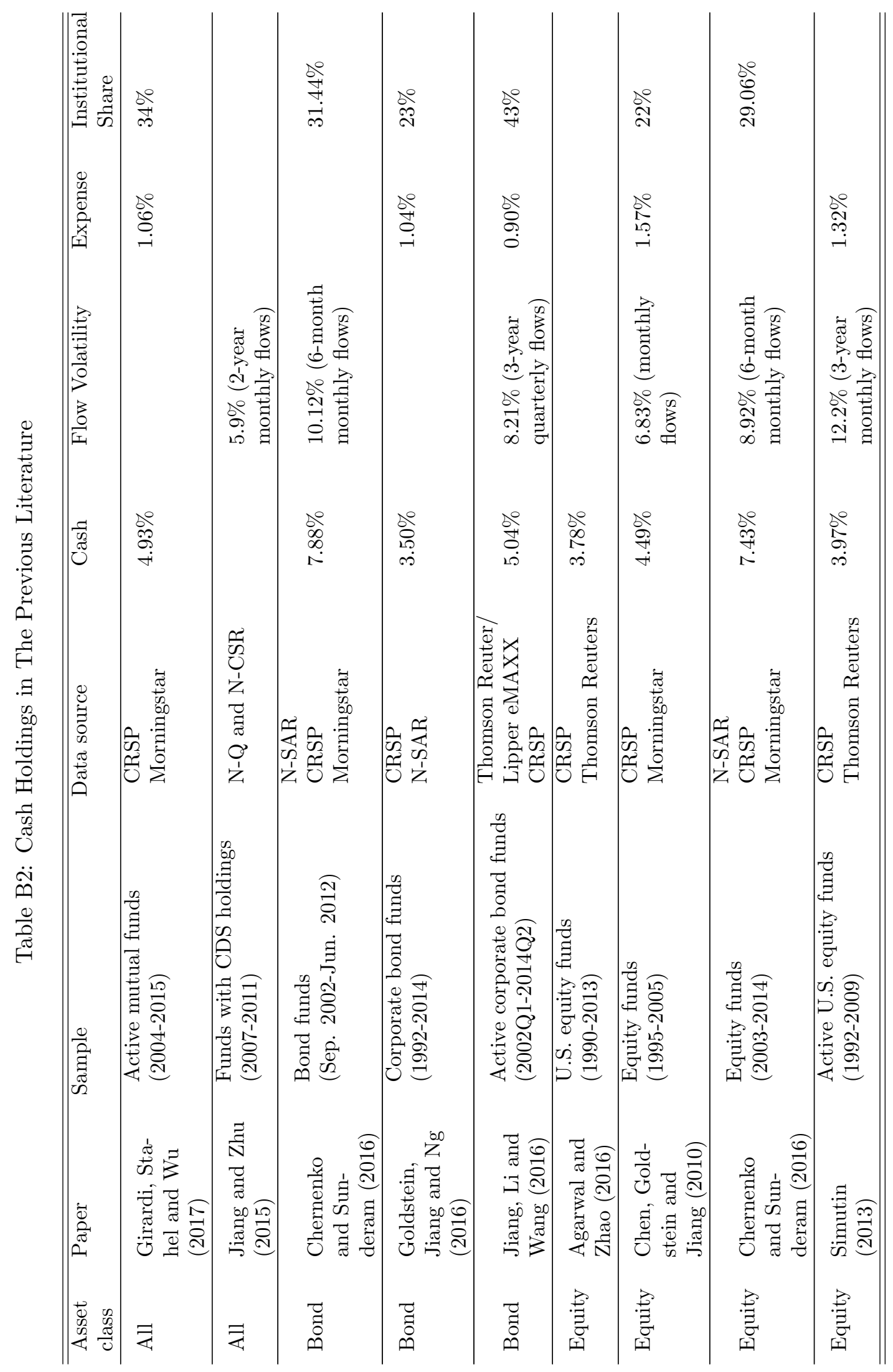




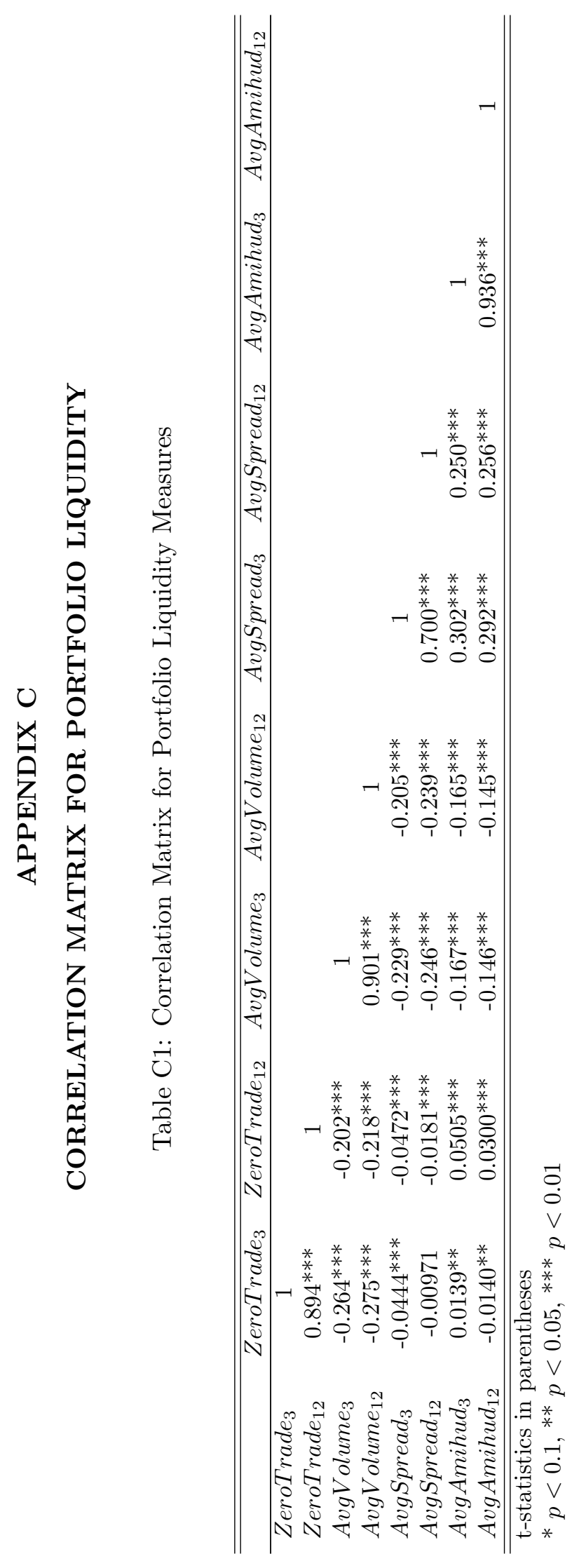




\section{REFERENCES CITED}

[1] Vikas Agarwal and Haibei Zhao. Interfund lending in mutual fund families: Role in liquidity management. 2016.

[2] Yakov Amihud. Illiquidity and stock returns: cross-section and time-series effects. Journal of Financial Markets, 5(1):31-56, 2002.

[3] Brad M Barber, Xing Huang, and Terrance Odean. Which factors matter to investors? evidence from mutual fund flows. The Review of Financial Studies, 29(10):2600-2642, 2016.

[4] Jonathan B Berk and Richard C Green. Mutual fund flows and performance in rational markets. Journal of Political Economy, 112(6):1269-1295, 2004.

[5] Utpal Bhattacharya, Jung H Lee, and Veronika K Pool. Conflicting family values in mutual fund families. The Journal of Finance, 68(1):173-200, 2013.

[6] Markus K Brunnermeier and Lasse Heje Pedersen. Market liquidity and funding liquidity. Review of Financial Studies, 22(6):2201-2238, 2008.

[7] Mark M Carhart. On persistence in mutual fund performance. The Journal of Finance, 52(1):57-82, 1997.

[8] Lorenzo Casavecchia and Ashish Tiwari. Cross trading by investment advisers: Implications for mutual fund performance. Journal of Financial Intermediation, 25:99$130,2016$.

[9] John Chalmers, Steve Liu, and Zhi Jay Wang. The difference a day makes: Timely disclosure and trading efficiency in the muni market. 2016.

[10] Qi Chen, Itay Goldstein, and Wei Jiang. Payoff complementarities and financial fragility: Evidence from mutual fund outflows. Journal of Financial Economics, 97(2):239-262, 2010.

[11] Sergey Chernenko and Adi Sunderam. Liquidity transformation in asset management: Evidence from the cash holdings of mutual funds. Fisher College of Business Working Paper, (2016-03):05, 2016.

[12] Judith Chevalier and Glenn Ellison. Risk taking by mutual funds as a response to incentives. The Journal of Political Economy, 105(6):1167-1200, 1997.

[13] Jaewon Choi and Seunghun Shin. Is there flow-driven price impact in corporate bond markets? 2016.

[14] Oleg Chuprinin, Massimo Massa, and David Schumacher. Outsourcing in the international mutual fund industry: An equilibrium view. The Journal of Finance, 70(5):2275-2308, 2015.

[15] Gjergji Cici and Scott Gibson. The performance of corporate bond mutual funds: Evidence based on security-level holdings. Journal of Financial and Quantitative Analysis, 47(01):159-178, 2012. 
[16] Joshua Coval and Erik Stafford. Asset fire sales (and purchases) in equity markets. Journal of Financial Economics, 86(2):479-512, 2007.

[17] Kent Daniel, Mark Grinblatt, Sheridan Titman, and Russ Wermers. Measuring mutual fund performance with characteristic-based benchmarks. The Journal of finance, 52(3):1035-1058, 1997.

[18] Diane Del Guercio, Egemen Genc, and Hai Tran. Playing favorites: Conflicts of interest in mutual fund management. Available at SSRN 2774273, 2016.

[19] Diane Del Guercio and Paula A Tkac. Star power: The effect of morningstar ratings on mutual fund flow. Journal of Financial and Quantitative Analysis, 43(4):907, 2008.

[20] Jens Dick-Nielsen, Peter Feldhütter, and David Lando. Corporate bond liquidity before and after the onset of the subprime crisis. Journal of Financial Economics, 103(3):471-492, 2012.

[21] Serdar Dinc, Isil Erel, and Rose Liao. Fire sale discount: Evidence from the sale of minority equity stakes. Journal of Financial Economics, 125(3):475-490, 2017.

[22] Darrell Duffie. Presidential address: asset price dynamics with slow-moving capital. The Journal of finance, 65(4):1237-1267, 2010.

[23] Roger M Edelen. Investor flows and the assessed performance of open-end mutual funds. Journal of Financial Economics, 53(3):439-466, 1999.

[24] Alexander Eisele, Tamara Nefedova, and Gianpaolo Parise. Are star funds really shining? cross-trading and performance shifting in mutual fund families. 2016.

[25] Alexander Eisele, Tamara Nefedova, Gianpaolo Parise, Kim Peijnenburg, et al. Trading Out of Sight: An Analysis of Cross-Trading in Mutual Fund Families. Centre for Economic Policy Research, 2017.

[26] Andrew Ellul, Chotibhak Jotikasthira, and Christian T Lundblad. Regulatory pressure and fire sales in the corporate bond market. Journal of Financial Economics, 101(3):596-620, 2011.

[27] Edwin J Elton, Martin J Gruber, Christopher R Blake, and Or Shachar. Why do closed-end bond funds exist? an additional explanation for the growth in domestic closed-end bond funds. Journal of Financial and Quantitative Analysis, 48(02):405$425,2013$.

[28] Francesco A Franzoni and Alberto Plazzi. What constrains liquidity provision? evidence from hedge fund trades. 2013.

[29] Alex Frino, Andrew Lepone, and Brad Wong. Derivative use, fund flows and investment manager performance. Journal of Banking \& Finance, 33(5):925-933, 2009.

[30] Jon A Fulkerson and Timothy B Riley. Mutual fund liquidity costs. Financial Management, 46(2):359-375, 2017. 
[31] José-Miguel Gaspar, Massimo Massa, and Pedro Matos. Favoritism in mutual fund families? evidence on strategic cross-fund subsidization. The Journal of Finance, 61(1):73-104, 2006.

[32] Mariassunta Giannetti and Bige Kahraman. Open-end organizational structures and limits to arbitrage. The Review of Financial Studies, 31(2):773-810, 2017.

[33] Giulio Girardi, Christof Stahel, and Youchang Wu. Cash management and extreme liquidity demand of mutual funds. 2017.

[34] Itay Goldstein, Hao Jiang, and David T Ng. Investor flows and fragility in corporate bond funds. Journal of Financial Economics, 2017.

[35] Luis Goncalves-Pinto and Juan M Sotes-Paladino. The invisible hand of internal markets in mutual fund families. 2016.

[36] Paul Hanouna, Jon Novak, Tim Riley, and Christof Stahel. Liquidity and flows of us mutual funds. Division of Economic and Risk Analysis White Paper, US Securities and Exchange Commission, 2015.

[37] Hao Jiang, Dan Li, and Ashley Wang. Dynamic liquidity management by corporate bond mutual funds. Available at SSRN, 2016.

[38] Wei Jiang and Zhongyan Zhu. Mutual fund holdings of credit default swaps: Liquidity management and risk taking. Technical report, Working Paper, Columbia University and CUHK, 2015.

[39] Jennifer Lynch Koski and Jeffrey Pontiff. How are derivatives used? evidence from the mutual fund industry. The Journal of Finance, 54(2):791-816, 1999.

[40] Alberto Manconi, Massimo Massa, and Ayako Yasuda. The role of institutional investors in propagating the crisis of 2007-2008. Journal of Financial Economics, 104(3):491-518, 2012.

[41] Massimo Massa. How do family strategies affect fund performance? when performance-maximization is not the only game in town. Journal of Financial Economics, 67(2):249-304, 2003.

[42] L'uboš Pástor and Robert F Stambaugh. Liquidity risk and expected stock returns. Journal of Political economy, 111(3):642-685, 2003.

[43] L'uboš Pástor, Robert F Stambaugh, and Lucian A Taylor. Do funds make more when they trade more? The Journal of Finance, 72(4):1483-1528, 2017.

[44] Mitchell A Petersen. Estimating standard errors in finance panel data sets: Comparing approaches. Review of Financial Studies, 22(1):435-480, 2009.

[45] Ronnie Sadka. Momentum and post-earnings-announcement drift anomalies: The role of liquidity risk. Journal of Financial Economics, 80(2):309-349, 2006.

[46] Christopher Schwarz and Mark Potter. Revisiting mutual fund portfolio disclosure. Review of Financial Studies, 2016. 
[47] Michael Schwert. Municipal bond liquidity and default risk. The Journal of Finance, 72(4):1683-1722, 2017.

[48] Andrei Shleifer and Robert Vishny. Fire sales in finance and macroeconomics. The Journal of Economic Perspectives, 25(1):29-48, 2011.

[49] Andrei Shleifer and Robert W Vishny. Liquidation values and debt capacity: A market equilibrium approach. The Journal of Finance, 47(4):1343-1366, 1992.

[50] Andrei Shleifer and Robert W Vishny. The limits of arbitrage. The Journal of Finance, 52(1):35-55, 1997.

[51] Mikhail Simutin. Cash holdings and mutual fund performance. Review of Finance, page $\mathrm{rft} 035,2013$.

[52] Erik R Sirri and Peter Tufano. Costly search and mutual fund flows. The Journal of Finance, 53(5):1589-1622, 1998.

[53] Xuemin Sterling Yan. The determinants and implications of mutual fund cash holdings: Theory and evidence. Financial Management, 35(2):67-91, 2006.

[54] Yao Zeng. A dynamic theory of mutual fund runs and liquidity management. 2017. 